JULIANA SHIMARA PIRES FERRÃO

Expressão de proteínas de comunicação e junções celulares no rúmen de fetos bovinos, bezerros recém-nascidos e bovinos adultos.

Tese apresentada ao Programa de PósGraduação Interunidades em Biotecnologia da Universidade de São Paulo, Instituto Butantan e Instituto de Pesquisas Tecnológicas para obtenção do Título de Doutora em Biotecnologia. 
JULIANA SHIMARA PIRES FERRÃO

\section{Expressão de proteínas de comunicação e junções celulares no rúmen de fetos bovinos, bezerros recém-nascidos e bovinos adultos.}

Tese apresentada ao Programa de Pós-Graduação Interunidades em Biotecnologia USP/Instituto Butantan/IPT para obtenção do Título de Doutora em Biotecnologia.

Área de Concentração: Biotecnologia

Orientador: Prof. Dr. Francisco Javier Hernandez Blazquez

Versão Original

São Paulo 


\section{CATALOGAÇÃO NA PUBLICAÇÃO (CIP) \\ Serviço de Biblioteca e informação Biomédica \\ do Instituto de Ciências Biomédicas da Universidade de São Paulo}

Ficha Catalográfica elaborada pelo(a) autor(a)

Shimara Pires Ferrão, Juliana

Expressão de proteínas de comunicação e junções celulares no rúmen de fetos bovinos, bezerros recémnascidos e bovinos adultos. / Juliana Shimara Pires Ferrão; orientador Francisco Javier Hernandez Blazquez. -- São Paulo, 2018. $105 \mathrm{p}$.

Tese (Doutorado)) -- Universidade de São Paulo, Instituto de Ciências Biomédicas.

1. Rúmen. 2. Conexinas. 3. Fetos bovinos. 4. Bezerros recém-nascidos. 5. Bovinos adultos. I. Javier Hernandez Blazquez, Francisco, orientador. II. Título. 


\section{UNIVERSIDADE DE SÃO PAULO \\ Programa de Pós-Graduação Interunidades em Biotecnologia}

Universidade de São Paulo, Instituto Butantan, Instituto de Pesquisas Tecnológicas

Candidato(a): Juliana Shimara Pires Ferrão

Título da Tese: Expressão de proteínas de comunicação e junções celulares no rúmen de fetos bovinos, bezerros recém-nascidos e bovinos adultos.

Orientador(a): Prof. Dr. Francisco Javier Hernandez Blazquez

A Comissão Julgadora dos trabalhos de Defesa da Tese de Doutorado, em sessão pública realizada a ..$/ . . .$. considerou

\section{( ) Aprovado(a) \\ ( ) Reprovado(a)}

Examinador(a): Asinatura:.

Nome:

Instituição:

Examinador(a): Asinatura:.

Nome:

Instituição:

Examinador(a): Asinatura:.

Nome:

Instituição:

Examinador(a): Asinatura:.

Nome:

Instituição:

Presidente: Asinatura:

Nome:

Instituição: 


\section{CERTIFICADO}

Certificamos que o Projeto intitulado "Expressão de proteínas de comunicação e de junçōes celulares no rúmen de fetos bovinos, bezerros recém-nascidos e bovinos adultos.". protocolado sob o CEUA n ${ }^{\circ} 8744171014$, sob a responsabilidade de Francisco Javier Hernandez Blazquez e equipe; Juliana Shimara Pires Ferrão - que envolve a produçäo, manutenção elou utilização de animais pertencentes ao filo Chordata, subfilo Vertebrata (exceto o homem), para fins de pesquisa científica (ou ensino) - encontra-se de acordo com os preceitos da Lei 11.794, de 8 de outubro de 2008, com o Decreto 6.899 , de 15 de jutho de 2009, com as normaș editadas pelo Conselho Nacional de Controle da Experimentação Animal (CONCEA), e foi aprovado pela Comissäo de Ética no Uso de Animais da Faculdade de Medicina Veterinária e Zootecnia da Universidade de Säo Paulo (CEUA/FMZV) em reuniäo de 19/08/2015.

We certify that the proposal "Expression of proteins of cell communication and cell junctions in the rumen of cattle fetuses, newborn calves and adult cattle.", utilizing 40 Bovines (40 males). protocol number CEUA 8744171014. under the responsibility of Francisco Javier Hernandez Blazquez and team; Juliana Shimara Pires Ferräo - which involves the production, maintenance and/or use of animals belonging to the phylum Chordata, subphylum Vertebrata (except human beings), for scientific research purposes (or teaching) - it's in accordance with Law 11.794, of October 82008 , Decree 6899 , of July 15, 2009, with the rules issued by the National Council for Control of Animal Experimentation (CONCEA), and was approved by the Ethic Committee on Animal Use of the School of Veterinary Medicine and Animal Science of São Paulo University (CEUAFMZV) in the meeting of 08/18/2015.

Vigência da Proposta: de 02/2014 a 02/2018

Área: Cirurgla

Procedência: Abatedouro

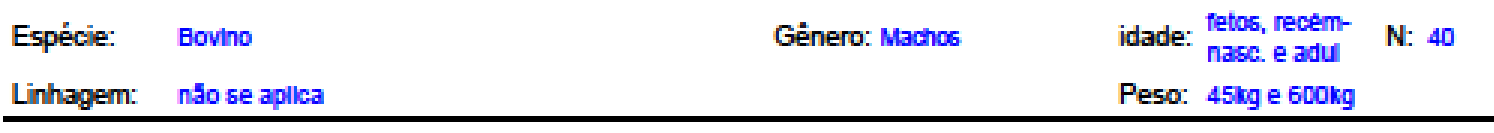

Săo Paulo, 16 de novembro de 2015

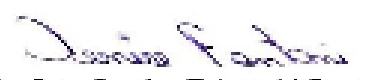

Profa. D\%è. Denise Tabacchi Fèntoni

Fresidente da Comissīo de Ética ro Uso de Áni Trais

raculdade de Medicina veterinarla e zcotecnia

Uriversidade de Säo Pau o 


\section{DEDICATÓRIA}

Aos meus pais, Wagner Pires Ferrão e Jeanete Aparecida Shimara Pires Ferrão, meus exemplos de dignidade, humildade, esforço e perseverança. Agradeço por me apoiarem em todas as decisões, por sempre estarem presentes quando eu precisei e por todos os ensinamentos. Amo muito vocês.

Ao meu companheiro e amor, Rennan Lopes Olio, por sempre estar ao meu lado, por todo apoio em todos os momentos, por todas as conversas, brincadeiras, trabalho e decisões. Por sempre estar presente, mesmo estando longe. Amo muito você.

Ao meu querido cão Neto, por todos os ensinamentos e pela paciência, por ser minha "cobaia" de treinamento após cada aula durante a graduação. Saudades eternas. Amo muito você.

Às minhas queridas e danadas gatas, Jujuba e Paçoca, que tornam nossos dias alegres únicos, mesmo quando são desobedientes e arteiras. Amo muito vocês.

A estes amores pacientes e incondicionais dedico este momento. 


\section{AGRADECIMENTOS}

Ao Professor Doutor Francisco Javier Hernandez Blazquez, pela dedicação, ensino e paciência durante esse período de convivência, e pela oportunidade de realizar esse trabalho. Muito obrigada por sempre estar presente e disposto a ajudar e ensinar, pelas conversas e pela confiança.

Aos meus amigos queridos, Diogo Nader Palermo, Flávio Costa, João Leonardo Mendonça, Patrícia Nogueira Ferraz, Rennan Lopes Olio, Simone Palmeira, Tathiana Iuri Hanasilo, por todo apoio, pela amizade e carinho, pelos conselhos e companheirismo. Muito obrigada.

À equipe do setor de Anatomia da FMVZ - USP, em especial à Ana Paula da Silva por toda a colaboração, ajuda e paciência nestes anos.

À equipe da secretaria do ICB III - USP, em especial à Fabia e Eliane, por toda a colaboração e ajuda.

Ao Prof. Dr. Francisco Palma Rennó, ao Dr. Guilherme Gomes da Silva e a todos da equipe do Laboratório de Pesquisa em Bovinos de Leite da USP de Pirassununga pela paciência, por toda ajuda e trabalho realizado em conjunto.

Ao Prof. Dr. Luiz Lehmann Coutinho, à Dra. Marcela Paduan e a todos da equipe do Centro de Genômica Funcional da ESALQ (USP de Piracicaba) pela paciência, por toda ajuda e trabalho realizado em conjunto.

A todos com os quais convivi durante este período, por todos os momentos compartilhados.

Ao Conselho Nacional de Desenvolvimento Científico e Tecnológico, por conceder a bolsa e possibilitar a execução deste estudo, nº 140243/2014-3.

À Fundação de Amparo à Pesquisa do Estado de São Paulo, por financiar grandes projetos que possibilitaram a execução deste estudo, por auxiliar e participar da realização de grandes sonhos, nº 2015/50095-3. 


\section{RESUMO}

Ferrão, J. S. P. Expressão de proteínas de comunicação e junções celulares no rúmen de fetos bovinos, bezerros recém-nascidos e bovinos adultos. 2018. 105f. Tese (Doutorado em Biotecnologia) - Instituto de Ciências Biomédicas, Universidade de São Paulo, São Paulo, 2018.

O estômago de ruminantes é um órgão complexo subdividido em quatro compartimentos: o rúmen, o retículo, o omaso e o abomaso, sendo os três primeiros os pré-estômagos ou pró-ventrículos. Cada um possui sua própria característica, responsável por mecanismos de ruminação essenciais. Junções gap são as únicas especializações na membrana celular que permitem a comunicação direta entre células adjacentes, enquanto que as junções de adesão são especializações que mantém a integridade tecidual. Sabe-se que elas contribuem para a homeostase tissular e são compostas por proteínas transmembrânicas chamadas conexinas (junções gap) e caderinas (junções de adesão). Além disso, essas junções estão também envolvidas no controle da proliferação celular, no controle de crescimento e diferenciação, apoptose, e a sincronização de funções eletrotônicas e metabólicas. Assim, o rúmen de bovinos pode ser um modelo para compreender a contribuição das conexinas e caderinas durante a diferenciação do epitélio ruminal a um estado funcional, que o transforma de epitélio de revestimento para um epitélio absortivo com funções de metabolização de substâncias, em especial o ácido lático e ácidos graxos. Dessa maneira, nossa hipótese é que as diferentes conexinas mudem sua dinâmica de expressão quanto ao tipo e localização, com repercussões na morfologia epitelial. Os objetivos do presente estudo foram a avaliação da expressão e localização das Conexinas 26, 32, 40 e 43 e da E-caderina no rúmen de fetos bovinos, bezerros recém-nascidos e bovinos adultos, além da avaliação morfológica do epitélio ruminal de através da microscopia óptica e eletrônica. Também possui como objetivo a avaliação da expressão gênica dessas proteínas no rúmen desses animais. Para isso, foi realizada a coleta de amostras do saco dorsal e do saco ventral do rúmen de fetos bovinos, bezerros recém-nascidos e bovinos adultos. Nos materiais coletados foram realizadas as técnicas de coloração com Hematoxilina-Eosina e morfometria, imunofluorescência, microscopia eletrônica de transmissão, extração de RNA total e sequenciamento genético. $\mathrm{Na}$ coleta do material as posições anatômicas observadas foram exatas às já descritas na literatura. O tecido ruminal apresentou diferenças morfométricas em relação às mensurações realizadas no tecido epitelial e na camada basal, nas idades estudadas. Além 
disso, foram observadas modificações teciduais ao longo do desenvolvimento ruminal na microscopia eletrônica de transmissão e na expressão das conexinas no tecido ruminal na imunofluorescência. A respeito da expressão das conexinas estudadas, ela difere em relação à idade dos animais e à localização no tecido ruminal, tornando evidente a necessidade de cada uma das conexinas em relação à idade, desenvolvimento e manutenção do tecido ruminal. A expressão tecidual da E-caderina apresentou-se semelhante nas idades estudadas. Em relação à expressão gênica e sequenciamento genético dessas proteínas, suas mudanças acompanharam as diferenças observadas na expressão tecidual através da imunofluorescência. Desse modo, pode-se concluir que ocorrem mudanças tanto na expressão tecidual quanto na expressão gênica dessas proteínas durante o desenvolvimento ruminal e sua manutenção enquanto adulto.

Palavras-chave: Rúmen. Conexinas. Fetos bovinos. Bezerros recém-nascidos. Bovinos adultos. 


\begin{abstract}
Ferrão, J. S. P. Expression of communication proteins and cellular junctions in the rumen of bovine fetuses, newborn calves and adult bovines. 2018. 105p. These (Ph.D in Biotechnology) - Instituto de Ciências Biomédicas, Universidade de São Paulo, São Paulo, 2018.
\end{abstract}

The stomach of ruminants is a complex organ subdivided into four compartments: the rumen, the reticulum, the omasum and the abomasum, the first three being the prestomachs or pro-ventricles. Each one has its own characteristic, responsible for essential rumination mechanisms. Gap junctions are the only cell membrane specializations that allow direct communication between adjacent cells, whereas adhesion junctions are specializations that maintain tissue integrity. It is known that they contribute to tissue homeostasis and are composed of transmembrane proteins called connexins (gap junctions) and cadherins (adhesion junctions). In addition, these junctions are also involved in the control of cell proliferation, growth and differentiation, apoptosis, and the synchronization of electrotonomic and metabolic functions. Thus, the bovine rumen may be a model for understanding the contribution of connexins and cadherins during the differentiation of the ruminal epithelium into a functional state, which transforms it from coating epithelium to an absorptive epithelium with metabolizing functions of substances, especially the lactic acid and fatty acids. Therefore, our hypothesis is that the different connexins change their expression dynamics regarding type and location, with repercussions on epithelial morphology. The objective of the present study was to evaluate the expression and location of Connexins 26, 32, 40 and 43 and E-cadherin in the rumen of bovine fetuses, newborn calves and adult bovines, as well as the morphological evaluation of ruminal epithelium through optical and electronic microscopy. It also aims to evaluate the gene expression of these proteins in the rumen of these animals. For that, samples were collected from the dorsal and the ventral sac from the rumen of bovine fetuses, newborn calves and adult bovines. Hematoxylin-Eosin staining techniques and morphometry, immunofluorescence, transmission electron microscopy, total RNA extraction and genetic sequencing were performed in the collected materials. During the collection of the material it was observed that anatomical positions were exact to those already described in the literature. The ruminal tissue presented morphometric differences in relation to the measurements made in the epithelial tissue and the basal layer, in the studied ages. In addition, tissue changes were observed along ruminal development in transmission electron microscopy and in the expression of 
connexins in ruminal tissue in immunofluorescence. Regarding the expression of the connexins studied, it differs in relation to the age of the animals and the location in the ruminal tissue, making evident the necessity of each of the connexins in relation to the age, development and maintenance of ruminal tissue. The tissue expression of E-cadherin was similar in the studied ages. In relation to the gene expression and genetic sequencing of these proteins, their changes accompanied the observed differences in tissue expression through immunofluorescence. Thus, it can be concluded that changes occur in both the tissue expression and the gene expression of these proteins during ruminal development and its maintenance as an adult.

Keywords: Rumen. Connexins. Bovine fetuses. Newborn calves. Adult bovine. 


\section{LISTA DE ILUSTRAÇÕES}

Figura 1- Esquema de estômago bovino e foto de fragmento de rúmen.

Figura 2- Coloração de Hematoxilina-Eosina em tecido ruminal de fetos bovinos com 110 e 150 dias de desenvolvimento.

Figura 3- Coloração de Hematoxilina-Eosina em tecido ruminal de bezerros recémnascidos e bovinos adultos

Figura 4- Mensuração da camada basal das porções dorsal e ventral do rúmen de fetos bovinos, bezerros recém-nascidos e bovinos adultos

Figura 5- Mensuração do epitélio das porções dorsal e ventral do rúmen de fetos bovinos, bezerros recém-nascidos e bovinos adultos, representados pelas médias entre suas porções dorsal e ventral.

Figura 6- Mensuração das papilas nas porções dorsal e ventral do rúmen de fetos bovinos, bezerros recém-nascidos e bovinos adultos

Figura 7- Microscopia Eletrônica de Transmissão do tecido ruminal de fetos (110 e 150 dias de desenvolvimento), bezerros recém-nascidos e bovinos adultos.

Figura 8- Microscopia Eletrônica de Transmissão do tecido ruminal: ênfase nos desmossomos

Figura 9- Imunofluorescência para Conexina 26: ênfase na camada basal

Figura 10- Imunofluorescência para Conexina 26: ênfase no tecido epitelial

Figura 11- Imunofluorescência para Conexina 32: ênfase na camada basal.

Figura 12- Imunofluorescência para Conexina 32: ênfase no tecido epitelial 60

Figura 13- Imunofluorescência para Conexina 40: ênfase na camada basal.

Figura 14- Imunofluorescência para Conexina 40: ênfase no tecido epitelial. 63

Figura 15- Imunofluorescência para Conexina 43: ênfase na camada basal 
Figura 16- Imunofluorescência para Conexina 43: ênfase no tecido epitelial

Figura 17- Imunofluorescência para E-caderina: ênfase na camada basal..................... 67

Figura 18- Imunofluorescência para E-caderina: ênfase no tecido epitelial..................... 69

Figura 19- Gel de Agarose 1\% dos fetos de 110 dias de gestação................................ 71

Figura 20- Gel de Agarose 1\% dos fetos de 150 dias de gestação................................. 71

Figura 21- Gel de Agarose 1\% dos bezerros recém-nascidos....................................... 72

Figura 22- Gel de Agarose 1\% dos bovinos adultos............................................... 72

Figura 23- Gráficos do RNA total das amostras de fetos de 110 e 150 dias de gestação analisadas através do Agilent 2100 Bioanalyser.

Figura 24- Gráficos do RNA total das amostras de bezerros recém-nascidos e bovinos adultos de gestação analisadas através do Agilent 2100 Bioanalyser

Figura 25- Gráfico mostrando a distância entre as diferenças de expressão média entre amostras, calculadas com base nos 500 genes com maior diferença de expressão.

Figura 26- Gráfico da Conexina 26 (GJB2)

Figura 27- Gráfico da Conexina 40 (GJA5)

Figura 28- Gráfico da Conexina 43 (GJA1) 83

Figura 29- Gráfico da E-caderina (CDH1) 84 


\section{LISTA DE TABELAS}

Tabela 1- Estimativa da idade gestacional segundo Noden e Lahunta (1990)

Tabela 2- Idade gestacional e desenvolvimento fetal (Noden e Lahunta, 1990; Hyttel, Sinowatz e Vejlsted, 2010)

Tabela 3- Anticorpos utilizados no estudo

Tabela 4- Anticorpos e concentrações utilizadas nas imunofluorescências

Tabela 5- Mensurações realizadas na camada basal dos fetos, bezerros recémnascidos e bovinos adultos.

Tabela 6- Mensurações realizadas no epitélio dos fetos, bezerros recém-nascidos e bovinos adultos.

Tabela 7- Mensurações realizadas nas papilas dos fetos, bezerros recém-nascidos e bovinos adultos.

Tabela 8- Taxa (em \%) de mapeamento por amostra do genoma de Bos taurus, mostrando reads mapeados e não mapeados.

Tabela 9- Número de genes diferencialmente expressos por contraste.

Tabela 10- Número de vias metabólicas KEGG diferencialmente reguladas entre os contrastes.

Tabela 11- Número de categorias "GO biological process" diferencialmente reguladas entre os contrastes.

Tabela 12- Número de categorias "GO molecular function" diferencialmente reguladas entre os contrastes.

Tabela 13- Número de categorias "GO cellular compartment" diferencialmente reguladas entre os contrastes. 


\section{LISTA DE QUADROS}

Quadro 1- Dados de quantificação das amostras realizadas no programa de NanoDrop2000.

Quadro 2- Análise do RIN (RNA Integrity Number) das amostras realizada no Laboratório de Biotecnologia Animal (ESALQ/USP) 


\section{SUMÁRIO}

1 INTRODUÇÃO .............................................................................................................................. 18

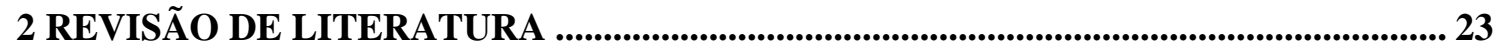

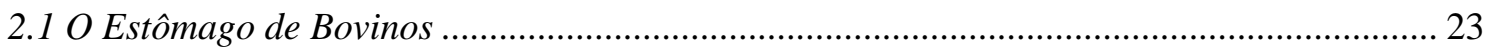

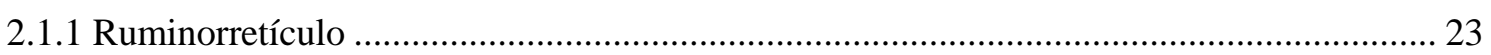

2.2 Desenvolvimento Pós-natal do Sistema Digestório de Bovinos .............................................. 24

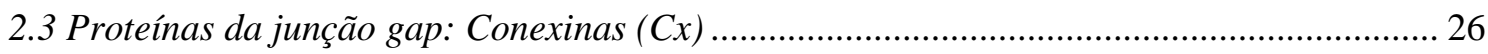

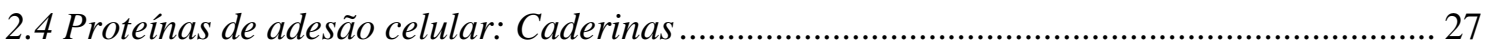

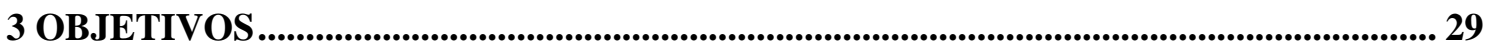

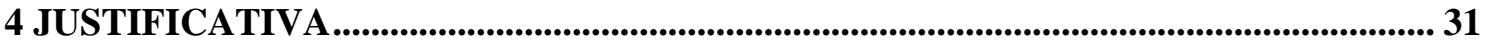

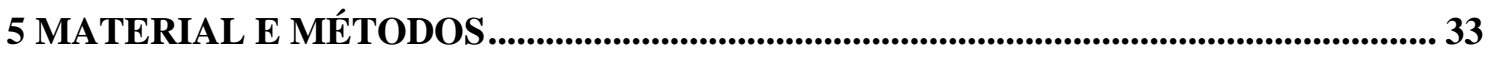

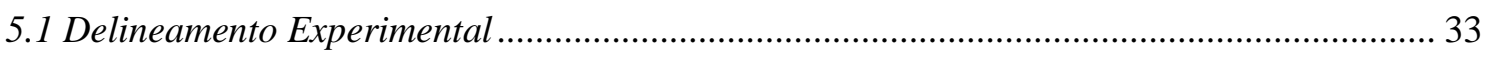

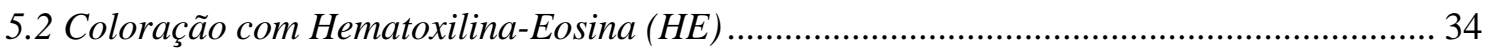

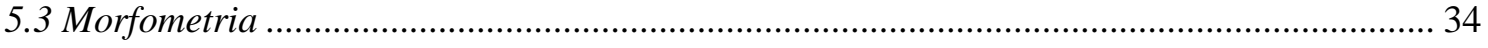

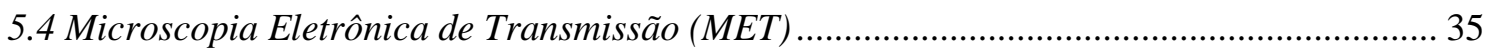

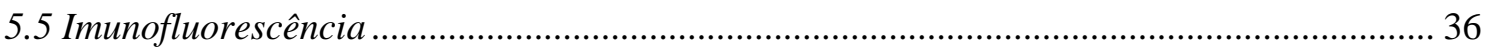

5.5.1 Imuno-Histoquímica de Fluorescência de Alta Sensibilidade (Tiramida-Fluoresceína).... 36

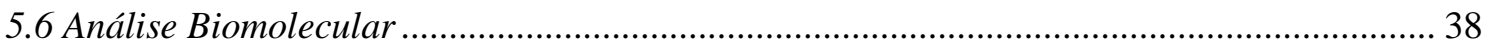

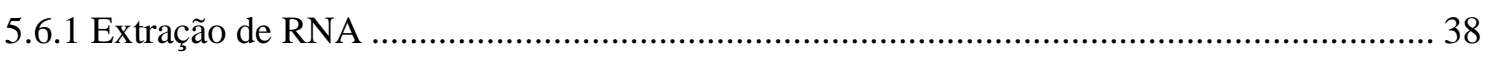

5.6.2 Preparo das Bibliotecas de mRNA e Sequenciamento Genético ...................................... 40

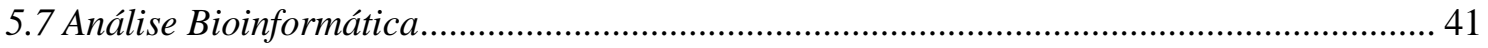

5.7.1 Avaliação e Pré-processamento dos Dados ............................................................................. 41

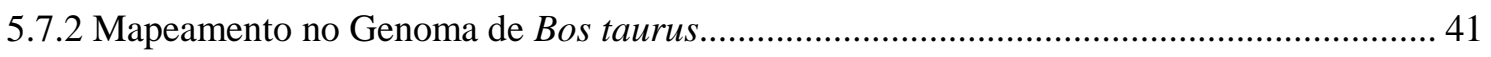

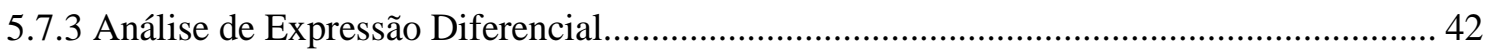

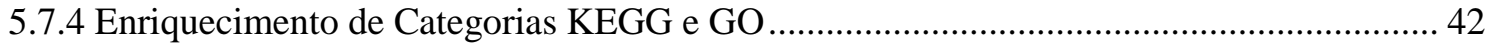

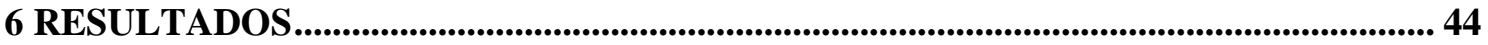

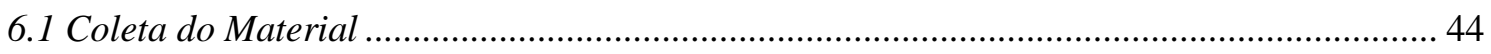

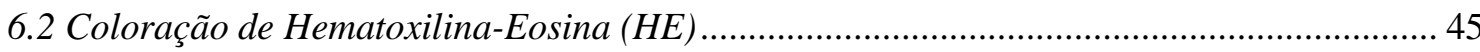




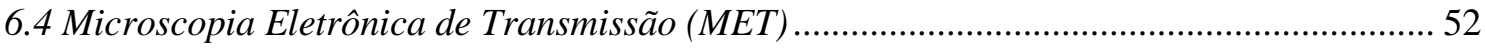

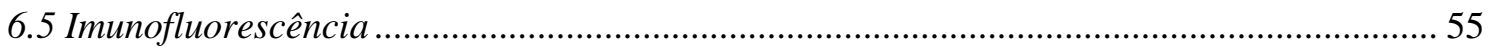

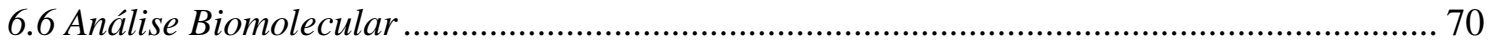

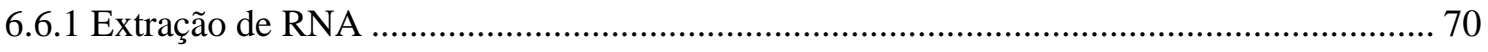

6.6.2 Preparo das bibliotecas de mRNA e sequenciamento genético.................................... 73

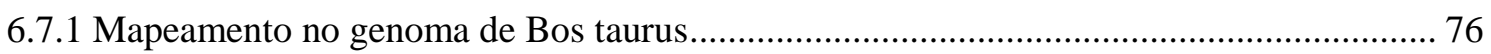

6.7.2 Análise de expressão diferencial ................................................................ 77

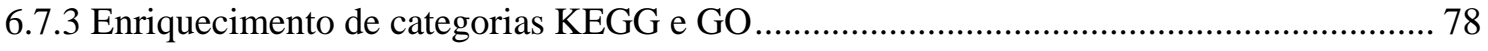

6.7.4 Comparação entre as diferentes proteínas estudadas - Cx26, Cx32, Cx40, Cx43 e E-

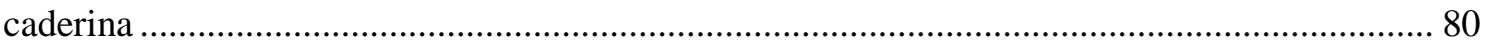

7 DISCUSSÃ

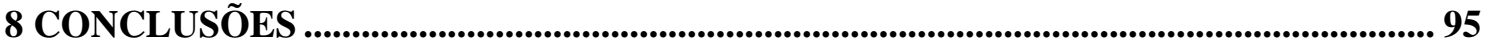

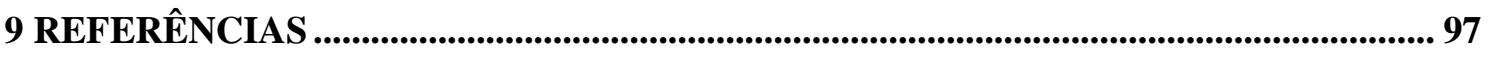

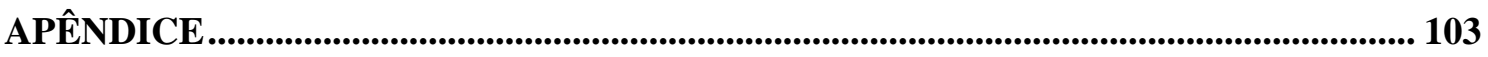


1 Introdução 


\section{INTRODUÇÃO}

O Brasil figura atualmente como um dos principais atores na produção e comércio de carne bovina no mundo, reflexo de um estruturado processo de desenvolvimento que elevou não só a produtividade como também a qualidade do produto brasileiro e, consequentemente sua competitividade e abrangência de mercado. No ano de 2015 o Brasil se posicionou como o maior rebanho bovino (209 milhões de cabeças), o segundo maior consumidor (38,6 kg/habitante/ano) e o segundo maior exportador (1,9 milhões toneladas equivalente carcaça) de carne bovina do mundo, tendo abatido mais de 39 milhões de cabeças. Dono de forte mercado consumidor interno (cerca de $80 \%$ do consumo), é dotado de expressivo e moderno parque industrial para processamento com capacidade de abate de quase 200 mil bovinos por dia. A exportação de carne bovina já representa 3\% das exportações brasileiras e um faturamento de 6 bilhões de reais e, em termos de produto interno bruto, representa $6 \%$ do PIB brasileiro ou $30 \%$ do PIB do Agronegócio, com um movimento superior a 400 bilhões de reais, que aumentou em quase $45 \%$ nos últimos 5 anos (GOMES; FEIJÓ; CHIARI, 2017).

Em relação à produção de leite no país, no $3^{\circ}$ trimestre de 2017, a aquisição de leite cru feita pelos estabelecimentos que atuam sob algum tipo de inspeção sanitária (Federal, Estadual ou Municipal) foi de 6,16 bilhões de litros. Esse volume foi 9,1\% maior que o registrado no trimestre imediatamente anterior e 5,4\% maior que o alcançado no mesmo trimestre em 2016. Diferente dos 3os trimestres de 2015 e 2016, esse trimestre apresentou um crescimento em relação ao mesmo período do ano anterior, apesar de ainda estar abaixo do nível alcançado no $3^{\circ}$ trimestre de 2014. Além disso, apesar de ser um grande importador de lácteos, o Brasil abriga um dos maiores rebanhos produtivos do mundo, com 23 milhões de cabeças, ficando atrás somente da Índia. No período de 2000 a 2015, a produção cresceu $72,3 \%$; o rebanho aumentou $28,7 \%$ e a produtividade, $33,8 \%$, porém ainda é baixa, de 1.525 litros/vaca/ano, um dos menores índices entre os principais países produtores de leite. (LORDÃO et al., 2017).

Para que ocorra uma maior produtividade, seja de carne ou de leite, é necessário que esses animais possuam uma dieta adequada e balanceada, para que sua conversão alimentar seja a mais eficiente possível. Assim, deve-se conhecer bem a anatomia e o desenvolvimento do trato digestivo desses animais, para que cada vez mais haja uma melhora nessa conversão alimentar e um aumento da produtividade do gado brasileiro. Dessa maneira, o conhecimento prévio sobre o funcionamento digestório e de absorção dos nutrientes pelos ruminantes é de extrema importância para o crescimento do mercado no Brasil.

O aparelho digestivo compreende os órgãos envolvidos com a recepção, a redução mecânica, a digestão química, e absorção de comida e bebida e com a eliminação de resíduos não absorvidos. Ele consiste no trato digestivo, que se estende desde a boca até o ânus, e certas glândulas (glândulas salivares, pâncreas e fígado) que drenam por 
intermédio de dutos que se abrem para o trato (VAN SOEST, 1982; ABBAS et al., 1995; DYCE; SACK; WENSING, 2010).

O estômago de ruminantes é um órgão complexo subdividido em quatro compartimentos: o rúmen, o retículo, o omaso e o abomaso, sendo que os três primeiros formam os pré-estômagos ou pró-ventrículos. Os pré-estômagos possuem um papel importante na fisiologia digestiva dos ruminantes, pois consistem no local onde processos físicos e bioquímicos relacionados à ruminação ocorrem e, particularmente, onde bactérias simbióticas realizam uma atividade intensa de fermentação através de digestão de celulose. Além disso, cada um dos três compartimentos possui sua própria característica, responsável por mecanismos de ruminação essenciais (ABBAS et al., 1995; SCALA; CORONA; MARUCCIO, 2011).

Para o ruminante recém-nascido (zero a 24 horas de vida), a falta de atividade proteolítica e de secreção de ácido hidroclórico evita a degradação das imunoglobulinas do colostro e um mecanismo pinocitótico de curta duração nos intestinos permitem que elas sejam absorvidas intactas. Na fase pré-ruminante ( 1 dia a 3 semanas de vida), o fechamento reflexo da goteira esofágica e a adequada formação de coalho de leite no abomaso são essenciais. Na fase transicional ( 3 a 8 semanas de vida), a ingestão de leite associada ao fechamento da goteira esofágica continua a permitir que o leite ultrapasse o ruminorretículo (denominação conjunta do retículo e do rúmen, pois formam um reservatório onde a ingesta é reduzida por processos de fermentação microbial), para que a formação do coalho do leite no abomaso ocorra paralelamente com o desenvolvimento acelerado dos pré-estômagos. Isso inclui a aquisição de microbiota através do contato com ruminantes mais velhos, o desenvolvimento de papilas e de folhetos omasais pelo metabolismo epitelial de ácidos graxos voláteis (AGVs), e o desenvolvimento muscular dos pré-estômagos através da ingestão de volumoso. O restante do período de desmame (a partir de 8 semanas de vida) mostra dependência de leite reduzida como fonte de nutrientes e uma maior dependência de volumoso. Os vários compartimentos gástricos aproximam-se das proporções adultas, e o estômago do ruminante cresce desproporcionalmente em relação ao restante dos órgãos enquanto o animal se aproxima da idade adulta (DUKES, 2004).

Os principais produtos finais da fermentação ruminal de carboidratos e proteínas são os AGVs (ácidos graxos voláteis). Eles são absorvidos diretamente pelo epitélio da parede dos pré-estômagos, onde alguns acetatos são inteiramente oxidados e onde o butirato e o propionato (em menor escala) passam por algumas mudanças metabólicas para posterior metabolização no fígado. AGVs e seus metabólitos entram na circulação geral como acetato, glicose (do propionato) e $\beta-\mathrm{OH} \mathrm{Bu}$ (do butirato) para se tornarem, nessa ordem, os principais substratos metabólicos nos ruminantes. Dada a importância do epitélio de revestimento na fisiologia da absorção e metabolização de AGVs, propionato e butirato, supõe-se que este epitélio integre a atividade absortiva e metabólica de suas células individuais em uma unidade funcional. Desse modo, outros sistemas fisiológicos bovinos também realizam a metabolização dessas substância para a formação de novos substratos, como ocorre na glândula mamária, onde eles também são utilizados na síntese 
de ácidos graxos de cadeia curta e média, característicos do leite de ruminantes (DUKES, 2004).

Para que ocorra a comunicação entre as células dos tecidos, durante suas interações sejam metabólicas, fisiológicas ou anatômicas, existem as junções comunicantes (ou junções tipo nexo ou gap), que constituem as únicas especializações na membrana celular que permitem a comunicação direta entre células adjacentes e sua integração funcional. Sabe-se que elas contribuem para a homeostase tissular e são compostas por proteínas transmembrânicas chamadas conexinas. Além disso, essas junções estão também envolvidas no controle da proliferação celular (AVANZO et al., 2006; DAGLI; HERNANDEZ-BLAZQUEZ, 2007; HIRABAYASHI et al., 2007; COGLIATI et al., 2011), no controle de crescimento e diferenciação (LOEWENSTEIN, 1979), apoptose (WILSON; CLOSE; TROSKO, 2000), e a sincronização de funções eletrotônicas e metabólicas (BRUZZONE; WHITE; PAUL, 1996). A exposição à radiação e lesão aguda tecidual induzem a desconexão de conexinas, resultando em dano tecidual (TROSKO; CHANG; MADHUKAR, 1990), além de também aparentar ser uma resposta de proteção que resulta em proliferação ativa tecidual e consequente recuperação (HIRABAYASHI et al., 2007).

Nos vertebrados, as junções comunicantes são formadas por membros de uma família de proteínas chamadas conexinas (Cx). Existem cerca de 21 tipos de conexinas expressas em humanos e 20 tipos em camundongos. Seus genes correspondentes são identificados com um símbolo iniciando com "GJ", enquanto que a nomenclatura utilizada para as proteínas é "Cx", seguida pelo número correspondente à massa molecular do polipeptídeo em $\mathrm{kDa}$ (quiloDalton). Diferenças e similaridades nas sequências das conexinas são utilizadas para definir subfamílias de conexinas e comparações de sequências entre espécies diferentes são utilizadas para a identificação de ortólogos. Atualmente, cinco subfamílias de conexinas são reconhecidas, sendo elas $\alpha, \beta, \gamma, \delta$ e $\varepsilon$ ou GJA, GJB, GJC, GJD e GJE (EVANS, 2015; BEYER; BERTHOUD, 2018). A junção de seis conexinas na membrana celular forma um hemicanal, que ao ligar-se ao hemicanal da célula adjacente forma o canal de comunicação entre essas células. Diferentes tipos de conexinas podem atuar em diferentes tipos teciduais. Por exemplo, as conexinas 26, 32, 40 e 43 podem ser encontradas no tecido epitelial. Além disso, a conexina 26 também possui um papel fundamental relacionado à surdez humana. Já a conexina 32 também é encontrada no fígado de várias espécies animais, enquanto que a conexina 40 é também encontrada na retina de bovinos e a conexina 43 é também encontrada no coração de várias espécies animais (MATESIC; TILLEN; SITARAMAYYA, 2003; TAVORA et al., 2013; EVANS, 2015; IGARASHI et al., 2016; SANECKA et al., 2016).

Além das conexinas, outras proteínas são de suma importância para a manutenção e organização das células, como as caderinas, que são proteínas responsáveis pela adesão entre células adjacentes, mantendo a organização tissular. As caderinas são uma superfamília de proteínas transmembrânicas, com papel crucial na morfogênese e homeostase tecidual. Elas diminuem a tensão interfacial célula-célula, promovendo um 
contato mais estreito entre as células adjacentes, além de estabilizar esse contato resistindo a forças mecânicas que possam tentar romper a relação entre as células em um tecido (PETTITT, 2005; MAÎTRE; HEISENBERG, 2013).

Ainda é necessário estudar o papel das proteínas da junção gap (conexinas) nos estômagos dos ruminantes, em especial o rúmen, uma vez que não há nenhum estudo da expressão de conexinas neste órgão. O papel destas proteínas na integridade tecidual, no comportamento celular e na manutenção da organização tecidual durante $o$ desenvolvimento ruminal (modificações que ocorrem em seu epitélio, desde sua formação embrionária até seu amadurecimento após o desmame de bezerros, passando de um estado afuncional a um estado funcional) ainda não é conhecida. Também não é conhecida a sequência temporal da expressão destas moléculas durante a fase de adaptação funcional do órgão. Os estudos mais próximos que podem servir de analogia ao que pode ser esperado no epitélio ruminal são os realizados na epiderme, que assim como o revestimento do rúmen, é um epitélio estratificado queratinizado, embora com propriedades funcionais diferentes. Na pele, diferentes conexinas foram correlacionadas com eventos específicos da diferenciação e cicatrização, sendo que a Cx43 é menos expressada no início da cicatrização. Uma aplicação prática deste conhecimento é que o uso de oligonucleotídios antissentido contra o RNAm da Cx43 acelera a cicatrização de feridas (WANG et al., 2007).

Assim, o rúmen de bovinos pode ser um modelo para compreender a contribuição das conexinas durante a diferenciação do epitélio ruminal a um estado funcional, que o transforma de epitélio de revestimento para um epitélio absortivo com funções de metabolização de substâncias, em especial o ácido lático e ácidos graxos.

Nossa hipótese é que as diferentes conexinas, em resposta aos processos de adaptação e especialização funcional do epitélio ruminal (seja por adaptação induzida pelo desenvolvimento do órgão ou pelas diferentes fases alimentares), mudem sua dinâmica de expressão quanto ao tipo e localização, com repercussões na morfologia epitelial. Vários estudos na área de nutrição de ruminantes buscam promover o máximo desenvolvimento das papilas ruminais e de seu epitélio o mais rápido possível com diferentes estratégias de desmame, contudo, para melhor controlar processos e prever resultados é preciso entender melhor como eles ocorrem, o que esperamos contribuir com este estudo. 


\section{Revisão de Literatura}




\section{REVISÃO DE LITERATURA}

\subsection{O Estômago de Bovinos}

O estômago dos ruminantes é, na verdade, um estômago simples modificado pela expansão acentuada da região esofágica em três divertículos distintos e volumosos, o rúmen, o retículo e o omaso, conhecidos coletivamente como pré-estômagos (próventrículos) ou compartimentos gástricos anteriores (VAN SOEST, 1982; DYCE; SACK; WENSING, 2010; FRANDSON, 2011). Eles são revestidos por epitélio estratificado pavimentoso (escamoso) não glandular e compreendem uma série de câmaras onde o alimento é submetido à digestão por microrganismos antes de passar através do trato digestório para a parte menor e glandular do estômago dos ruminantes, o abomaso (FRANDSON, 2011; SCALA; CORONA; MARUCCIO, 2011). No entanto, o abomaso possui um epitélio prismático simples e glandular, semelhante ao encontrado em estômagos de espécies monogástricas (SCALA; CORONA; MARUCCIO, 2011).

\subsubsection{Ruminorretículo}

Por sua relação funcional e anatômica, o retículo e o rúmen em geral são denominados de forma coletiva como ruminorretículo (FRANDSON, 2011). O rúmen e o retículo juntos formam um reservatório no qual o material alimentar não processado, não digerido por enzimas digestivas de mamíferos, é reduzido por processos de fermentação microbial. Alguns dos mais simples produtos são diretamente assimilados, enquanto outros são susceptíveis à digestão convencional no trato digestivo (DYCE; SACK; WENSING, 2010).

A abertura do esôfago (o cárdia) fica aproximadamente no nível do sétimo espaço intercostal e abre-se no espaço dorsal comum ao rúmen e ao retículo. A mucosa na região do cárdia forma duas pregas musculares fortes que, juntas, criam um sulco que se estende do cárdia ao omaso, o sulco ruminorreticular (FRANDSON, 2011). O rúmen é comprimido lateralmente e se estende da cárdia até a fissura pélvica, do região dorsal à região ventral abdominal, e da região lateral esquerda à linha medial, especialmente caudal e ventral, onde pode atingir o flanco lateral direito inferior (DYCE; SACK; WENSING, 2010).

O retículo é o mais cranial dos compartimentos gástricos anteriores. Sua mucosa tem cristas que se interseccionam e justificam a designação do órgão como um "favo de mel" (VAN SOEST, 1982; FRANDSON, 2011). O retículo posiciona-se cranialmente ao rúmen, abaixo da sexta à oitava costela e principalmente à esquerda do plano medial. Sua 
posição possibilita a aplicação de pressão externa na expectativa de induzir dor, quando o retículo está doente (DYCE; SACK; WENSING, 2010).

O retículo e o rúmen são divididos ventralmente por uma prega ruminorreticular muscular espessa. O rúmen estende-se dessa prega até a pelve e preenche quase inteiramente o lado esquerdo da cavidade abdominal (FRANDSON, 2011). O rúmen é subdividido internamente em compartimentos por pilares musculares, que correspondem a sulcos visíveis no exterior do órgão. Os pilares longitudinais direito e esquerdo formam um círculo constritor quase completo no plano horizontal e dividem o rúmen em sacos dorsal e ventral (DYCE; SACK; WENSING, 2010).

O saco dorsal é o maior compartimento, sendo contínuo cranialmente com o retículo sobre a prega ruminorreticular, de modo que os dois compartimentos compartilhem um espaço dorsal. Caudalmente, o saco dorsal é ainda subdividido pelos pilares coronários dorsais, que formam um círculo incompleto delimitando o saco cego dorsal. A parte caudal do saco ventral forma um divertículo, o saco cego ventral, separado do restante do saco ventral pelos pilares coronários ventrais (VAN SOEST, 1982; DYCE; SACK; WENSING, 2010).

Como no restante dos compartimentos gástricos anteriores, a mucosa que reveste o rúmen é de epitélio estratificado pavimentoso (escamoso) não glandular. As partes mais ventrais de ambos os sacos do rúmen contêm numerosas papilas em foram de plumas com até 1 centímetro de comprimento, mas praticamente não há papilas na região dorsal do rúmen (FRANDSON, 2011).

\subsection{Desenvolvimento Pós-natal do Sistema Digestório de Bovinos}

Ao nascer, o estômago dos bovinos é preparado para a digestão de leite. O abomaso predomina e é excepcional não somente pelo seu tamanho, que supera a capacidade das outras câmaras juntas, mas também pelo grau de maturidade estrutural que atinge (VAN SOEST, 1982; CUNNINGHAM, 2004; DYCE; SACK; WENSING, 2010).

No ruminante jovem, o desenvolvimento da digestão gástrica pode ser considerado como possuindo quatro fases (CUNNINGHAM, 2004; DUKES, 2004; DYCE; SACK; WENSING, 2010). Na fase do recém-nascido (zero a vinte e quatro horas de vida), onde, ao nascer, os pré-estômagos são pequenos e não funcionais, representando $39 \%$ do total do estômago, não possuem microbiota, e as papilas ruminorreticulares e os folhetos omasais são muito rudimentares. A dieta consiste somente de colostro, que é particularmente rico em imunoglobulinas. $\mathrm{O}$ abomaso não secreta ácido ou pepsinogênio durante o primeiro dia, assim, não há digestão gástrica. Na fase pré-ruminante (1 dia a 3 semanas de vida), a ingestão principal é de leite. O jovem ruminante, durante a segunda metade deste período, pode experimentar alimentos sólidos, mas isso possui pequena 
contribuição à sua ingestão de nutrientes. Conforme o leite passa pela faringe, contrações nas bordas em espiral da goteira esofágica causam seu encurtamento e aposição para produzir um tubo temporário conectando os orifícios cárdico e retículo-omasal. Assim, o leite ultrapassa o ruminorretículo, flui rapidamente através do omaso relaxado e termina no abomaso. $\mathrm{O}$ ato de sugar e a presença de leite no abomaso suscitam secreções abomasais. As secreções abomasais consistem de uma enzima proteolítica, renina ou quimosina e ácido hidroclorídrico. A ação da renina no leite produz um coágulo duro ou coalhada, consistindo de caseinogênios, precipitados como caseinato de cálcio. A fração remanescente do leite, o soro, consiste em proteínas do soro (albuminas e globulinas) e lactose (DUKES, 2004).

Durante a fase de transição ( 3 a 8 semanas de vida), volumes de leite são ingeridos $\mathrm{e}$, simultaneamente, o animal começa a ingerir progressivamente grandes quantidades de volumoso, que são responsáveis pelo início do desenvolvimento de glândulas salivares e do ruminorretículo (DUKES, 2004). Os pré-estômagos são estéreis ao nascimento, mas são rapidamente colonizados pelas bactérias do meio, principalmente por organismos facultativos. À medida que a fermentação bacteriana começa a ocorrer no meio anaeróbio dos pré-estômagos, a ação das bactérias cria no rúmen um ambiente redutivo típico. Este ambiente cria condições necessárias para o crescimento e o estabelecimento de anaeróbios estritos (VAN SOEST, 1982; CUNNINGHAM, 2004; DUKES, 2004). Fermentação microbiana da forragem produz ácidos graxos voláteis (AGVs) que são essenciais para o desenvolvimento das papilas ruminorreticulares e dos folhetos omasais. A grande quantidade de volumoso é responsável pelo desenvolvimento muscular e do tamanho do ruminorretículo, para o início da motilidade cíclica e para a ruminação efetiva. A fase de desmama inicia-se, aproximadamente, com o início do declínio natural da lactação, assim, progressivamente, uma menor quantidade de leite está disponível durante o desmame. As taxas e formas dos ciclos de motilidade dos pré-estômagos alcançam as características de animais adultos e a pepsina substitui a renina nas secreções abomasais (DUKES, 2004).

O desenvolvimento do epitélio dos pré-estômagos ocorre paralelamente ao desenvolvimento geral do órgão. Ao nascimento, o epitélio é fino e as papilas são pequenas ou inexistentes. A exposição do epitélio aos ácidos graxos voláteis (AGV) parece estimular o desenvolvimento das papilas, bem como o desenvolvimento do órgão como um todo (CUNNINGHAM, 2004).

Os principais produtos finais da fermentação de carboidratos e proteínas são os AGVs. Apesar dos três pré-estômagos possuírem revestimento epitelial escamoso estratificado, grande parte dos AGVs produzida é absorvida através de suas paredes. Cerca de metade dos AGVs absorvidos por difusão passiva estão em estado indissociável, e o restante é absorvido como ânions por difusão facilitada, eficazmente em troca por íons bicarbonato (carbonato de hidrogênio). Durante a absorção através das paredes dos préestômagos, grande parte do ácido butírico nos ovinos, e em menor quantidade nos bovinos, é metabolizada (oxidada) para cetona, o $\beta$-hidroxibutirato $(\beta-\mathrm{OH} \mathrm{Bu}$ ou $3-\mathrm{OH}$ $\mathrm{Bu}$ ). Assim, o ácido butírico absorvido aparece na circulação geral quase que inteiramente 
como $\beta-\mathrm{OH} \mathrm{Bu}$. Essa cetona é rapidamente metabolizada por quase todos os tecidos do corpo e é utilizada para fornecer as primeiras 4 unidades de carbono na síntese mamária de aproximadamente metade dos ácidos graxos de cadeia curta e média (de C4 a C16) característicos do leite de ruminantes. Por sua vez, o propionato é o único AGV capaz de ser usado para gluconeogênesis através da sua conversão para oxaloacetato. $\mathrm{O}$ acetato, o AGV mais abundante na circulação e substrato metabólico principal dos ruminantes, é utilizado pela maioria dos tecidos para formar a acetil coenzima A, que reage com o oxaloacetato para formar citrato para ser usado do ciclo de Krebs. Na glândula mamária, ele também é utilizado na síntese de ácidos graxos de cadeia curta e média. É utilizado para, aproximadamente, metade das primeiras 4 unidades de carbono em cada cadeia de ácido graxo e para todas as unidades de carbono restantes em cadeias com até $\mathrm{C} 16$. $\mathrm{O}$ acetato, similarmente, é o principal precursor na síntese da gordura corporal dos ruminantes (DUKES, 2004).

\subsection{Proteínas da junção gap: Conexinas $(C x)$}

Junções gap são as únicas especializações na membrana celular que permitem a comunicação entre células adjacentes. Sabe-se que elas contribuem para a homeostase tissular e são compostas por proteínas transmembrânicas chamadas conexinas. Além disso, essas junções estão também envolvidas no controle da proliferação celular (AVANZO et al., 2006; DAGLI; HERNANDEZ-BLAZQUEZ, 2007; COGLIATI et al., 2011).

O papel das junções gap formadas pelas conexinas está relacionado na regulação homeostática de sistemas multicelulares (HIRABAYASHI et al., 2007). Junções gap estão relacionadas na regulação homeostática de várias funções celulares, entre elas controle de crescimento e diferenciação (LOEWENSTEIN, 1979), apoptose (WILSON; CLOSE; TROSKO, 2000), e a sincronização de funções eletrotônicas e metabólicas (BRUZZONE; WHITE; PAUL, 1996). A exposição à radiação e lesão aguda tecidual induzem a desconexão de conexinas, resultando em dano tecidual (TROSKO; CHANG; MADHUKAR, 1990). Por outro lado, a desconexão das conexinas durante a fase aguda de lesão celular também aparenta ser uma resposta de proteção que resulta em proliferação ativa tecidual e consequente recuperação (HIRABAYASHI et al., 2007).

Em seu estudo, Wang e Daniel (2001) mostraram a presença das conexinas 40 e 43 (Cx40 e Cx43) no trato gastrointestinal (esfíncter distal do esôfago, antro gástrico, íleo e cólon) de cães, através da determinação da distribuição dessas conexinas utilizando marcação com anticorpos (imunofluorescência).

O papel das junções gap na mucosa gástrica durante o processo regenerativo de injúria da mucosa induzida por etanol também foi estudado (ENDO et al., 1995). O reparo 
morfológico é diferente da recuperação da maturação e proliferação celulares na mucosa gástrica regenerativa (DAGLI; HERNANDEZ-BLAZQUEZ, 2007).

De acordo com Dagli e Hernandez-Blazquez (2007), pode-se verificar que a capacidade de comunicação intercelular de junções gap e as proteínas dessas junções, as conexinas, estão associadas com controle de crescimento em processos patológicos nãoneoplásicos. Em geral, na maioria das situações e em vários tipos de tecidos, existe uma correlação direta entre a comunicação intercelular de junções gap e a expressão de conexinas, e uma correlação inversa entre a comunicação intercelular de junções gap e crescimento celular.

Avanzo et al. (2006) demonstraram que o desenvolvimento de adenomas pulmonares está associado com a redução na expressão das conexinas 32 e 43 (Cx32 e Cx43). Foi também demonstrado um papel importante da Cx43 na carcinogênese pulmonar: a supressão de um dos alelos da Cx43 aumenta a suscetibilidade de carcinogênese pulmonar em camundongos. A ausência da expressão da Cx32 está associada com a transformação neoplásica induzida por uretano em células alveolares pulmonares do tipo II, gerando adenomas.

\subsection{Proteínas de adesão celular: Caderinas}

As caderinas são uma superfamília de proteínas transmembrânicas agrupadas pela presença de uma ou mais repetições de caderina em seus domínios extracelulares. Matrizes destes domínios de aproximadamente 110 resíduos formam as superfícies intermoleculares responsáveis pela formação de interações célula-célula mediada por caderina. A informação estrutural da análise de vários domínios de caderina indica que os íons de cálcio se ligam a locais entre repetições de caderina adjacentes (CRs), formando uma barra rígida. No entanto, a compreensão do mecanismo pelo qual essa interface de adesão é formada vem principalmente do estudo das caderinas clássicas dos vertebrados (PETTITT, 2005).

Ao regular a formação e estabilidade de contato, as caderinas desempenham um papel crucial na morfogênese e na homeostase dos tecidos. Maitre e Heisenberg (2013) revisaram as três principais funções das caderinas na formação e estabilidade dos contatos célula-célula. Duas dessas funções levam a uma diminuição da tensão interfacial no contato célula-célula formadora, promovendo assim a expansão do contato - primeiro, proporcionando tensão de adesão que diminui a tensão interfacial no contato célula-célula e, em segundo lugar, sinalizando ao citoesqueleto de actomiosina, a fim de reduzir a tensão do córtex e, portanto, a tensão interfacial no contato. A terceira função das caderinas na formação de contato célula-célula é estabilizar o contato resistindo às forças mecânicas que puxam o contato. 
3 Objetivos 


\section{OBJETIVOS}

Avaliar a expressão e localização da E-caderina e das Conexinas 26, 32, 40 e 43 do rúmen de fetos bovinos (110 e 150 dias de desenvolvimento), bezerros recém-nascidos e bovinos adultos. Preparo de bibliotecas de mRNA e sequenciamento genético da mucosa ruminal de todas as fases estudadas para identificar as adaptações moleculares sofridas pela mucosa ruminal na transição da mesma de um estado afuncional, antes do povoamento bacteriano, para um estado funcional na ruminação e absorção de nutrientes por este órgão. Além disso, avaliar morfologicamente por microscopia óptica e eletrônica o epitélio ruminal. 
4 Justificativa 


\section{JUSTIFICATIVA}

Ainda é necessário estudar o papel das proteínas da junção gap (conexinas) nos estômagos dos ruminantes, em especial o rúmen, uma vez que não há nenhum estudo da expressão de conexinas neste órgão. O papel destas proteínas na integridade tecidual, no comportamento celular e na manutenção da organização tecidual durante $o$ desenvolvimento ruminal (modificações que ocorrem em seu epitélio, desde sua formação embrionária até seu amadurecimento após o desmame de bezerros, passando de um estado afuncional a um estado funcional) ainda não é conhecida. Também não é conhecida a sequência temporal da expressão destas moléculas durante a fase de adaptação funcional do órgão. Os estudos mais próximos que podem servir de analogia ao que pode ser esperado no epitélio ruminal são os realizados na epiderme, que assim como o revestimento do rúmen, é um epitélio estratificado queratinizado, embora com propriedades funcionais diferentes. Na pele, diferentes conexinas foram correlacionadas com eventos específicos da diferenciação e cicatrização, sendo que a Cx43 é menos expressada no início da cicatrização. Uma aplicação prática deste conhecimento é que o uso de oligonucleotídios antissentido contra o RNAm da Cx43 acelera a cicatrização de feridas (WANG et al., 2007).

Assim, o rúmen de bovinos pode ser um modelo para compreender a contribuição das conexinas durante a diferenciação do epitélio ruminal a um estado funcional, que o transforma de epitélio de revestimento para um epitélio absortivo com funções de metabolização de substâncias, em especial o ácido lático e ácidos graxos.

Nossa hipótese é que as diferentes conexinas, em resposta aos processos de adaptação e especialização funcional do epitélio ruminal (seja por adaptação induzida pelo desenvolvimento do órgão ou pelas diferentes fases alimentares), mudem sua dinâmica de expressão quanto ao tipo e localização, com repercussões na morfologia epitelial. Vários estudos na área de nutrição de ruminantes buscam promover o máximo desenvolvimento das papilas ruminais e de seu epitélio o mais rápido possível com diferentes estratégias de desmame, contudo, para melhor controlar processos e prever resultados é preciso entender melhor como eles ocorrem, o que esperamos contribuir com este estudo. 


\section{Material e Métodos}




\section{MATERIAL E MÉTODOS}

\subsection{Delineamento Experimental}

Foi realizada a coleta de amostras do saco dorsal e do saco ventral do rúmen de fetos bovinos (com idades aproximadamente de 110 e 150 dias de desenvolvimento aproximadamente $240 \mathrm{~mm}$ e $370 \mathrm{~mm}$ de comprimento, respectivamente) (NODEN; LAHUNTA, 1990; HYTTEL; SINOWATZ; VEJLSTED, 2010) e bovinos adultos em abatedouros, e bezerros recém-nascidos. Os bezerros recém-nascidos foram adquiridos na Faculdade de Medicina Veterinária e Zootecnia da USP (FMVZ/USP) no campus de Pirassununga e foram eutanasiados imediatamente após o nascimento no Centro de Apoio à Pesquisa e Ensino da FMVZ/USP em Pirassununga. O material colhido foi dividido de acordo com a idade dos animais (Tabelas 1 e 2). A eutanásia dos bezerros recém-nascidos foi realizada através de aplicação de xilazina $(3 \mathrm{ml} / \mathrm{kg}$ ) por via endovenosa, seguida de aplicação de $20 \mathrm{ml}$ de cloreto de potássio $(\mathrm{KCl})$, também por via endovenosa.

Tabela 1 - Estimativa da idade gestacional.

\begin{tabular}{cc}
\hline Idade & Crow-rump (cm) \\
\hline $40-60$ & $1-5$ \\
\hline $60-80$ & $6-10$ \\
\hline $80-100$ & $11-15$ \\
\hline $100-110$ & $16-20$ \\
\hline $110-125$ & $21-25$ \\
\hline $125-140$ & $26-30$ \\
\hline $140-150$ & $31-35$ \\
\hline $150-160$ & $36-40$ \\
\hline $160-170$ & $41-45$ \\
\hline $170-180$ & $46-50$ \\
\hline $180-190$ & $51-55$ \\
\hline $190-200$ & $56-60$ \\
\hline $200-210$ & $61-65$ \\
\hline $210-225$ & $66-70$ \\
\hline $225-230$ & $71-75$ \\
\hline $230-240$ & $76-80$ \\
\hline $240-260$ & $81-85$ \\
\hline $260-270$ & $86-90$ \\
\hline $270-280$ & $91-95$ \\
\hline
\end{tabular}

Fonte: Adaptada de Noden e Lahunta, 1990. 
Tabela 2 - Idade gestacional e desenvolvimento fetal.

\begin{tabular}{cc}
\hline Idade & Desenvolvimento \\
\hline 110 dias de gestação & $\begin{array}{c}\text { diferenciação completa dos estômagos (pré- } \\
\text { estômagos e abomaso); tamanhos relativos dos } \\
\text { quatro compartimentos estomacais no feto são } \\
\text { comparáveis com os encontrados no adulto }\end{array}$ \\
\hline (240 mm de comprimento) & todos os órgãos desenvolvidos e diferenciados \\
\hline
\end{tabular}

Fonte: Adaptada de Noden e Lahunta (1990) e de Hyttel, Sinowatz e Vejlsted (2010).

\subsection{Coloração com Hematoxilina-Eosina (HE)}

Parte do material coletado foi conservado em solução fixadora de formol $10 \%$ tamponado (tampão fosfato). Em seguida, foi realizado procedimento de desidratação em sequência crescente de etanol (70\%, $90 \%$ e absoluto) e xilol (etanol/xilol, xilol I e II), sendo então o material incluso em parafina. Os cortes teciduais $(5 \mu \mathrm{m})$ foram desparafinizados em xilol (I e II), reidratados em uma série de etanol em concentrações decrescentes (absoluto I e II, 90\%, 70\%). Em seguida, foi realizada a coloração com Hematoxilina por 3 minutos, seguida de lavagem em água corrente durante 5 minutos. Então, foi realizada a coloração com Eosina durante 7 minutos, seguida pela desidratação dos cortes em ordem crescente de etanol e fechamento das lâminas com lamínula e solução selante Permount®.

\subsection{Morfometria}

Para a realização da mensuração do tecido epitelial ruminal, da camada basal e das papilas ruminais, foi utilizado o programa Zen® (Carl Zeiss Microscopy GmbH, Alemanha). Utilizando-se a coloração HE (Hematoxilina-Eosina) foi possível medir a espessura de ambas as porções no rúmen dos fetos, dos bezerros recém-nascidos e dos bovinos adultos, com o auxílio da barra de escala utilizando a ferramenta 'Straight' do programa.

Para cada avaliação foram fotografados 5 campos por lâmina, utilizando a câmera AxioCam HRc Zeiss (Carl Zeiss Microscopy GmbH, Alemanha), com a objetiva de 20x para os fetos de 110 e 150 dias de desenvolvimento, com a objetiva de 10x para os 
bezerros recém-nascidos e com a objetiva de $4 \mathrm{x}$ para os bovinos adultos, realizando 5 mensurações por foto.

\subsection{Microscopia Eletrônica de Transmissão (MET)}

O material foi fixado em Glutaraldeído 2,5\% em tampão cacodilato gelado com $\mathrm{pH} 7,2$. Foram inicialmente fragmentados em cortes com espessura de $5 \mathrm{~mm}$ realizados em rúmen (regiões dorsal e ventral) de bovinos (fetos, bezerros e adultos), logo após a eutanásia, mantidos no fixador em tubos de coleta, em temperatura de $4^{\circ} \mathrm{C}$. Após a fixação, novos fragmentos com espessura de $1 \mathrm{~mm}$ foram realizados a partir dos fragmentos inicias de rúmen (regiões dorsal e ventral) já fixados, sendo eles mantidos no fixador em um segundo tubo de coleta, em temperatura de $4^{\circ} \mathrm{C}$. Para os fragmentos de rúmen (regiões dorsal e ventral) dos fetos foram utilizados o tecido completo (epitélio, tecido conjuntivo, tecido muscular). Para os fragmentos de rúmen (regiões dorsal e ventral) dos bezerros, parte do tecido muscular foi retirada, utilizando o tecido epitelial com o mínimo de outros tecidos presentes.

Os fragmentos em $1 \mathrm{~mm}$ de espessura permaneceram imersos no fixador por 2 horas após o corte. Foi feita a lavagem dos fragmentos em solução de lavagem Ósmiofosfato $1 \%$, seguida da permanência em solução de ósmio-fosfato $1 \%$ por 2 horas, em temperatura ambiente, agitando manualmente a cada 30 minutos. Em seguida, foi realizada uma lavagem rápida em solução de acetato de uranila $0,5 \%$. Os fragmentos, então, permaneceram em solução de acetato de uranila a $0,5 \%$ com sacarose a $10,56 \mathrm{~g} / 100 \mathrm{ml}$, por 24 horas, à $4^{\circ} \mathrm{C}$. Após esse período, os fragmentos foram rapidamente lavados em água destilada. Então, os fragmentos foram desidratados em bateria crescente de etanol (2 vezes de 10 minutos em álcool 70\%, 2 vezes de 10 minutos em álcool 95\%, 4 vezes de 10 minutos em álcool 100\%), seguida por 2 vezes de 10 minutos em óxido de propileno. Após esse procedimento, foi realizada a infiltração dos fragmentos com óxido de propileno mais resina em partes iguais, com agitação por rotação durante 6 horas em temperatura ambiente. Para a inclusão, os fragmentos foram colocados em resina pura "overnight" à $37^{\circ} \mathrm{C}$, em moldes de silicone e levados à estufa de $72^{\circ} \mathrm{C}$ a $75^{\circ} \mathrm{C}$ durante 24 horas. Após a polimerização da resina, os blocos foram aparados e levados ao ultramicrótomo para obtenção de cortes de $0,5 \mu \mathrm{m}$ de espessura. Os cortes foram corados segundo a técnica de Richardson (1960), utilizando-se uma mistura imediata de partes iguais de azur II a 1\% em água destilada com azul de metileno a $1 \%$ em borato de sódio a $1 \%$. Após a coloração, os cortes foram lavados em água corrente e observados ao microscópio óptico. Quando as estruturas da região a serem estudadas mostraram características favoráveis ao estudo preconizado, os blocos correspondentes foram levados ao ultramicrótomo e retirados cortes ultrafinos, de aproximadamente $70 \mathrm{~nm}$. Então, os cortes foram colhidos em telas de cobre de 200 malhas e contrastados com acetato de uranila a $2 \%$ em água destilada durante 1 hora, lavados em água destilada e contrastados com citrato de chumbo $0,5 \%$ em água destilada, durante 30 minutos. Em 
seguida, foram examinados os cortes ultrafinos e as elétron-micrografias em microscópio eletrônico.

\subsection{Imunofluorescência}

$\underline{\text { 5.5.1 Imuno-Histoquímica de Fluorescência de Alta Sensibilidade (Tiramida- }}$ Fluoresceína)

Parte do material coletado foi conservado em Metacarn, permanecendo nele por oito horas. Após a inclusão do material em parafina e realizados os cortes histológicos $(5 \mu \mathrm{m})$, os cortes foram desparafinizados em xilol (I e II), reidratados em uma série de etanol em concentrações decrescentes (absoluto I e II, 90\%, 70\%) e colocados em tampão citrato por 5 minutos em temperatura ambiente. Em seguida, as lâminas foram incubadas em tampão citrato em panela de pressão (aproximadamente $100^{\circ} \mathrm{C}$ ) durante 5 minutos, permanecendo em temperatura ambiente por 30 minutos para resfriarem. Elas foram, então, incubadas em solução tampão de bloqueio TNB por 30 minutos. Na sequência, foram incubadas com os anticorpos contra as proteínas de interesse (Conexinas 26, 32, 40 ou 43, E-caderina) (Tabelas 3 e 4 ) durante 18 horas (overnight) à $4^{\circ} \mathrm{C}$. Após este período, foram lavadas três vezes ( 5 minutos cada) em tampão TNT sob agitação. Sequencialmente, os cortes foram incubados com anticorpo secundário biotinilado anticoelho (produzido em suíno) ou anti-camundongo (produzido em cabra) (Tabela 3), por uma hora em câmara úmida, e as lâminas foram lavadas novamente por 3 vezes ( 5 minutos cada) com tampão TNT sob agitação.

Posteriormente, as lâminas foram incubadas com Estreptavidina-Peroxidase (kit TSA $^{\text {TM }}$ - Fluorescein System, NEL701A001KT, Perkin Elmer, EUA) diluída na concentração [1:200] em tampão TNT, por 30 minutos em câmara escura. Em seguida, as lâminas foram novamente lavadas em tampão TNT 3 vezes de 5 minutos cada, sendo então, incubadas com Tiramida-Fluoresceína diluída na concentração [1:200] por 10 minutos em câmara úmida. Após 3 lavagens de 5 minutos cada em tampão TNT, foram incubadas em Iodeto de Propídio diluído na concentração [1:100] por 10 minutos, sendo em seguida fechadas com lamínula e Prolong Antifade ${ }^{\circledR}$.

As análises foram realizadas utilizando-se o microscópio Olympus BX60F5 (Olympus Optical Co., Ltd., Japão), a câmera AxioCam HRc Zeizz (Carl Zeiss Microscopy GmbH, Alemanha) e o programa Zen Blue Zeiss (Carl Zeiss Microscopy $\mathrm{GmbH}$, Alemanha). 
Tabela 3 - Anticorpos utilizados no estudo.

\begin{tabular}{|c|c|c|c|c|c|}
\hline ANTICORPO & DESCRIÇÃO & EMPRESA & $\begin{array}{l}\text { CONTROLE } \\
\text { POSITIVO }\end{array}$ & $\begin{array}{c}\text { APLICAÇÃO } \\
\text { (CONCENTRAÇÃO) }\end{array}$ & ALVO \\
\hline $\begin{array}{l}\text { Anti-Conexina } 26 \\
\text { (Anti-GJB2) }\end{array}$ & $\begin{array}{l}\text { Policlonal } \\
\text { Coelho }\end{array}$ & $\begin{array}{c}\text { Abcam } \\
(\text { ab65969) }\end{array}$ & Fígado de rato & $5 \mu \mathrm{g} / \mathrm{ml}$ & $\begin{array}{c}\text { Membrana celular } \\
\text { (junção gap - Conexina } \\
26 \text { ) }\end{array}$ \\
\hline $\begin{array}{l}\text { Anti-Conexina } 32 \\
\text { (Anti-GJB1) }\end{array}$ & $\begin{array}{l}\text { Policlonal } \\
\text { Coelho }\end{array}$ & $\begin{array}{c}\text { Abcam } \\
(\text { ab66613) }\end{array}$ & $\begin{array}{c}\text { Intestino } \\
\text { humano; fígado }\end{array}$ & $4-8 \mu \mathrm{g} / \mathrm{ml}$ & $\begin{array}{c}\text { Membrana celular } \\
\text { (junção gap - Conexina } \\
\text { 32) }\end{array}$ \\
\hline $\begin{array}{l}\text { Anti-Conexina } 40 \\
\text { (Anti-GJA5) }\end{array}$ & $\begin{array}{l}\text { Policlonal } \\
\text { Coelho }\end{array}$ & $\begin{array}{c}\text { Abcam } \\
(\mathrm{ab3} 3580)\end{array}$ & $\begin{array}{l}\text { Placenta; } \\
\text { fígado }\end{array}$ & $1: 200$ & $\begin{array}{c}\text { Membrana celular } \\
\text { (junção gap - Conexina } \\
40 \text { ) }\end{array}$ \\
\hline $\begin{array}{c}\text { Anti-Conexina } 43 \\
\text { (Anti-GJA1 } \\
{[\text { CXN-6]) }} \\
\end{array}$ & $\begin{array}{l}\text { Monoclonal } \\
\text { Camundongo }\end{array}$ & $\begin{array}{c}\text { Abcam } \\
(\text { ab11369) }\end{array}$ & Coração & $1: 200$ & $\begin{array}{c}\text { Membrana celular } \\
\text { (junção gap - Conexina } \\
43 \text { ) } \\
\end{array}$ \\
\hline E-Caderina & $\begin{array}{l}\text { Policlonal } \\
\text { Coelho }\end{array}$ & $\begin{array}{c}\text { Novus } \\
\text { Biological } \\
\text { (NBP2- } \\
16258 \text { ) }\end{array}$ & Coração & $1: 100$ a $1: 1000$ & $\begin{array}{l}\text { Membrana celular } \\
\text { (junção celular) }\end{array}$ \\
\hline $\begin{array}{c}\text { Anticorpo } \\
\text { Secundário } \\
\text { Biotinilado Cabra } \\
\text { anti-camundongo }\end{array}$ & $\begin{array}{c}\text { Policlonal } \\
\text { Camundongo }\end{array}$ & $\begin{array}{c}\text { Abcam } \\
(\text { ab97021) }\end{array}$ & - & $1: 200$ a $1: 5000$ & IgG de camundongo \\
\hline $\begin{array}{c}\text { Anticorpo } \\
\text { Secundário } \\
\text { Biotinilado Suíno } \\
\text { anti-coelho }\end{array}$ & $\begin{array}{l}\text { Policlonal } \\
\text { Coelho }\end{array}$ & $\begin{array}{c}\text { Dako } \\
(\mathrm{E} 0353)\end{array}$ & & $1: 300$ a $1: 4000$ & IgG de coelho \\
\hline
\end{tabular}


Tabela 4 - Anticorpos e concentrações utilizadas nas imunofluorescências.

\begin{tabular}{|c|c|c|c|}
\hline ANTICORPO & IDADE & CONCENTRAÇÃO & CONTROLE POSITIVO \\
\hline \multirow{4}{*}{ Anti-Cx26 } & Feto 110 dias & $1: 400$ & \multirow{4}{*}{ Fígado de rato [1:400] } \\
\hline & Feto 150 dias & $1: 400$ & \\
\hline & Bezerros & $1: 600$ & \\
\hline & Adultos & $1: 400$ & \\
\hline \multirow{4}{*}{ Anti-Cx32 } & Feto 110 dias & $1: 300$ & \multirow{4}{*}{ Fígado de rato [1:300] } \\
\hline & Feto 150 dias & $1: 300$ & \\
\hline & Bezerros & $1: 1200$ & \\
\hline & Adultos & $1: 300$ & \\
\hline \multirow{4}{*}{ Anti-Cx40 } & Feto 110 dias & $1: 800$ & \multirow{4}{*}{ Fígado de rato [1:400] } \\
\hline & Feto 150 dias & $1: 800$ & \\
\hline & Bezerros & $1: 3000$ & \\
\hline & Adultos & $1: 400$ & \\
\hline \multirow{4}{*}{ Anti-Cx43 } & Feto 110 dias & $1: 800$ & \multirow{4}{*}{ Coração de rato [1:800] } \\
\hline & Feto 150 dias & $1: 800$ & \\
\hline & Bezerros & $1: 800$ & \\
\hline & Adultos & $1: 1200$ & \\
\hline \multirow{4}{*}{ Anti-E-caderina } & Feto 110 dias & $1: 500$ & \multirow{4}{*}{ Coração de rato [1:500] } \\
\hline & Feto 150 dias & $1: 300$ & \\
\hline & Bezerros & $1: 400$ & \\
\hline & Adultos & $1: 300$ & \\
\hline
\end{tabular}

\subsection{Análise Biomolecular}

\section{$\underline{\text { 5.6.1 Extração de RNA }}$}

O RNA total foi extraído do tecido epitelial dos fetos (110 e 150 dias de desenvolvimento gestacional), dos bezerros recém-nascidos e dos bovinos adultos (5 amostras de cada idade, totalizando 20 amostras) utilizando-se o protocolo do reagente Trizol $^{\circledR}$, de acordo com as instruções do fabricante (Invitrogen ${ }^{\mathrm{TM}}$ Corporation, Carlsbad, CA, EUA).

As amostras, ao serem coletadas, foram imediatamente congeladas em nitrogênio líquido e transportadas até o laboratório onde o experimento foi realizado. Para o preparo das amostras, seguido pelo processamento das mesmas, todo o tecido epitelial foi separado do restante dos tecidos (conjuntivo e muscular). Em seguida, o tecido epitelial de cada amostra foi pesado (em torno de $0,2 \mathrm{~g}$ ) e colocado em microtubo contendo $500 \mu \mathrm{l}$ de Trizol ${ }^{\circledR}$. A seguir, as amostras foram homogeneizadas em Politron (homogeneizador 
de tecidos PRO200, PRO Scientific Inc., EUA) de haste permanente e acrescidas de mais $500 \mu 1$ de Trizol ${ }^{\circledR}$, sendo novamente homogeneizadas manualmente. Os microtubos foram centrifugados por 10 minutos, com $11.500 \mathrm{rpm}$ a $4{ }^{\circ} \mathrm{C}$. Logo após, o sobrenadante foi transferido para novo microtubo (permanecendo em temperatura ambiente por 5 minutos) e o restante foi descartado. Foram então, acrescidos $200 \mu 1$ de clorofórmio, homogeneizados em vórtex por 10 segundos e permaneceram em temperatura ambiente por 3 minutos. As preparações foram, em seguida, centrifugadas durante 15 minutos, com $11.500 \mathrm{rpm}$ a $4^{\circ} \mathrm{C}$. Após a centrifugação foi possível observar que se formaram 3 fases no microtubo, uma mais densa e rosa, permanecendo na região inferior do microtubo (fase contendo DNA), uma mais delgada e esbranquiçada, de densidade média, permanecendo na região intermediária do microtubo (fase proteica) e uma fase incolor, menos densa, permanecendo na região superior do microtubo (fase de RNA). A fase de RNA (incolor e superior) foi transferida para novo microtubo (e o restante descartado), foram acrescidos $500 \mu 1$ de álcool isopropílico seguido de homogeneização, permanecendo em temperatura ambiente durante 10 minutos. Em seguida, as amostras foram centrifugadas durante 10 minutos, com 11.500rpm a $4^{\circ} \mathrm{C}$. Foram, então, formados os pellets de RNA. O sobrenadante foi descartado e foram acrescidos $1000 \mu 1$ de etanol $75 \%$ para lavagem gentil dos pellets através da inversão dos microtubos. Então, os microtubos foram novamente centrifugados durante 5 minutos, com $9.000 \mathrm{rpm}$ a $4{ }^{\circ} \mathrm{C}$. O sobrenadante foi removido e os pellets foram secos, seguidos de sua eluição com água RNAse free (Ultra Pure ${ }^{\mathrm{TM}}$ Distilled Water DNAse, RNAse Free - Life Technology, Califórnia, EUA).

A quantidade e a pureza do RNA total foram determinadas pela leitura em espectrofotômetro (260nm - NanoDrop ND-2000, Thermo Scientific, Califórnia, EUA). A leitura das amostras em NanoDrop foi realizada através da utilização de $1 \mu 1$ de cada amostra colocada no aparelho, e a análise feita através do programa de computador NanoDrop 2000 (NanoDrop ND-2000, Thermo Scientific, Califórnia, EUA). Apenas amostras com RNA total apresentando relação 260/280nm entre 1,8 e 2,0 foram utilizadas para as análises de RNAseq.

A integridade e a pureza do RNA total foram determinadas por eletroforese em gel de agarose $1 \%$ contendo SYBR $^{\circledR}$ Safe $\left(\mathrm{SYBR}^{\circledR}\right.$ Safe DNA gel stain, Life Technologies, Califórnia, EUA). Para o preparo do gel de agarose foi utilizado $1 \%$ de agarose em relação à solução TAE $1 X$ (Ultra Pure ${ }^{\text {TM }}$ DNA Typing Grade ${ }^{\circledR} 50 X$ TAE Buffer, Thermo Fisher, Califórnia, EUA) e 10\% de corante de gel SYBR ${ }^{\circledR}$ Safe. Após a solidificação do gel de agarose, as amostras foram colocadas em seus poços para a realização da corrida eletroforética. As amostras foram previamente preparadas adicionando $5 \mu 1$ de amostra, $4 \mu 1$ de RNAse free e $1 \mu 1$ de corante Blue Juice (10X Blue Juice $^{\text {TM }}$ Gel loading Buffer, Life Technologies, Califórnia, EUA). Como referência, foi utilizado um marcador padrão de bandas de $1 \mathrm{~kb}$ (1 kb Plus DNA Ladder, Life Technologies, Califórnia, EUA). 
O preparo das bibliotecas de mRNA e o sequenciamento das amostras foi realizado no Laboratório de Biotecnologia Animal, na Escola Superior de Agricultura "Luiz de Queiroz" (ESALQ/USP).

A qualidade e a integridade do RNA total foram analisadas com o Agilent 2100 Bioanalyser (Agilent Technologies). Apenas amostras com RNA total apresentando RNA Integrity Number (RIN) maior ou igual a 7,0 foram utilizadas para as análises de RNAseq.

Cada amostra, contendo de 1 a $4 \mu \mathrm{g}$ de RNA total foi purificada de acordo com o protocolo descrito pela Illumina, utilizando microesferas magnéticas ligadas a oligos dT para separação do RNA ribossômico. O mRNA purificado foi fragmentado em tampão específico (Illumina, San Diego, EUA). A síntese da primeira fita de cDNA foi realizada com a enzima Superscript II (Invitrogen). A síntese da segunda fita de cDNA foi realizada com as enzimas RNAse e DNA Pol I (Illumina, San Diego, EUA). As extremidades das moléculas foram tratadas com as enzimas T4 DNA Polymerase e Klenow DNA Polymerase (Illumina, San Diego, EUA) para geração de extremidades abruptas. A extremidade 3' foi fosforilada com a enzima T4 PNK (Illumina, San Diego, EUA) e a adenilação na extremidade 3' foi realizada com a enzima Klenow exo (Illumina, San Diego, EUA). Então, foram ligados aos adaptadores com uso da enzima T4 DNA Ligase (Illumina, San Diego, EUA). As bibliotecas foram purificadas e amplificadas $(200 \mathrm{pb} \pm 30 \mathrm{pb})$ por meio de PCR com primers específicos para os adaptadores (Illumina, San Diego, EUA).

Após o término da SamplePrep, a qualidade das bibliotecas foi validada no Agilent 2100 Bioanalyser (Agilent Technologies) usando o chip DNA 1000, com intuito de verificar se o procedimento foi bem-sucedido e se as amostras apresentam a maior parte dos fragmentos próximos do tamanho de $260 \mathrm{pb}$.

A seguir, as bibliotecas foram quantificadas individualmente via PCR em Tempo Real (RT-qPCR), com o uso do Kit KAPA Library Quantification (KAPA Biosystems), o qual possui seis amostras padrões de concentrações (entre 20 a 0,0002 pM) e tamanho de fragmento conhecido (452 pb) presentes no kit. A partir dos valores de Ct dos padrões foram determinadas as concentrações das amostras por meio de uma regressão linear. Depois de calculadas essas concentrações, elas foram diluídas novamente para uma concentração padronizada, combinadas e, então, inseridas na lâmina de sequenciamento para a clusterização.

O sequenciamento do mRNA foi realizado com a tecnologia de sequenciamento de nova geração por meio do equipamento HiSeq2500 (Illumina, San Diego, EUA), de acordo com as instruções do fabricante e foi utilizado o protocolo de pair-end reads. Com uso do kit TruSeq PE Cluster Kit v3-cBot-HS (Illumina, San Diego, EUA), as amostras foram ligadas a oligos complementares posicionados na superfície das canaletas da lâmina, e posteriormente amplificadas, resultando em clusters (agrupamentos) de fragmentos iguais. A 
sequência dos agrupamentos foi determinada com uso do kit TruSeq SBS kit v3-HS (Illumina, San Diego, EUA), (200 cycles), conforme recomendações do fabricante. Cada canaleta teve seis amostras e cada amostra foi sequenciada até gerar cerca de 10 milhões de reads por biblioteca.

Os níveis de expressão diferencial identificados pelo sequenciamento de mRNA foram validados por PCR quantitativo em tempo real (qPCR).

\subsection{Análise Bioinformática}

\section{$\underline{\text { 5.7.1 Avaliação e Pré-processamento dos Dados }}$}

Os dados obtidos pelo HiSeq 2500 (Illumina, Inc., San Diego, CA) foram analisados pelo programa Real Time Analysis (fornecido pela Illumina), que faz o base call das imagens do sequenciamento, convertendo-as em sequências no formato fastq, com cada base acompanhada de um escore de qualidade Phred (EWING et al., 1998). Após a conversão para fastq, a avaliação inicial das leituras do sequenciamento foi feita

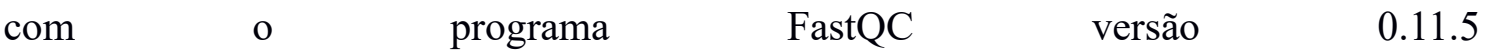
(http://www.bioinformatics.babraham.ac.uk/projects/fastqc/). A filtragem das bases com qualidade baixa, das sequências de adaptadores e de vetores foi feita com o programa BBDuk, do pacote BBTools versão 37.48 (http://sourceforge.net/projects/bbmap/). O banco de dados de vetores usado foi 0 UniVec (http://www.ncbi.nlm.nih.gov/tools/vecscreen/univec/). Leituras menores que 75 pares de bases após filtragem foram removidas.

\subsubsection{Mapeamento no Genoma de Bos taurus}

Após a filtragem, as leituras do sequenciamento de cada amostra foram alinhadas contra o genoma bovino versão UCSC bosTau8, obtida na página iGenomes da Illumina (http://support.illumina.com/sequencing/sequencing_software/igenome.html).

O mapeamento e a contagem das leituras foram feitos com o programa STAR versão 2.5.3 ${ }^{\mathrm{a}}$ (DOBIN et al., 2013). Leituras com mapeamento ambíguo foram descartadas na contagem utilizada para a estimativa de expressão gênica diferencial. 


\subsubsection{Análise de Expressão Diferencial}

Após obtenção das contagens, a análise de expressão gênica diferencial foi realizada com o programa DESeq2 versão 1.18.1 (LOVE; HUBER; ANDERS, 2014), um pacote do R/Bioconductor (GENTLEMAN et al., 2004). A análise foi realizada na seguinte sequência: a) as contagens obtidas pelo STAR foram lidas no R; b) genes com contagens muito baixas foram removidos da análise; c) as contagens de cada biblioteca foram normalizadas em relação à profundidade de sequenciamento de cada amostra; d) os dados foram descritos por um modelo linear generalizado (GLM), ajustando uma binomial negativa; e) aplicou-se filtragem independente automática dos dados (BOURGON; GENTLEMAN; HUBER, 2010), o que diminui o número de testes realizados e aumenta o poder da análise; f) e, finalmente, um teste Wald foi usado para testar expressão diferencial gene a gene entre os contrastes de interesse, com os valores de $\mathrm{p}$ sendo corrigidos com o critério de taxa falsa descoberta (fdr) para controlar a quantidade de falsos positivos (BENJAMINI; HOCHBERG, 1995). Como as diferenças entre os fetos, os bezerros e os adultos são muito numerosas, o teste realizado foi para diferenças de expressão maior do que 4 vezes (ou $\log 2$ (fold-change) $>2$ ).

\subsubsection{Enriquecimento de Categorias KEGG e GO}

O teste de enriquecimento de categorias GO (ASHBURNER et al., 2000) e vias metabólicas KEGG (OGATA et al., 1999) foi feito com o pacote do R/Bioconductor GAGE versão 2.28.0 (LUO et al., 2009). GAGE implementa uma versão do teste de enriquecimento de conjuntos de genes (SUBRAMANIAN et al., 2005), na forma de um teste de Kolmogorov-Smirnov em uma lista de genes ordenada por log2(fold-change). Este teste verifica se algum conjunto de genes está representado acima do esperado no topo da lista de genes, ou seja, entre os genes com maior diferença de expressão. Os resultados das vias metabólicas KEGG enriquecidas foram visualizados com o pacote Pathview versão 1.18.0 (LUO; BROUWER, 2013). São analisadas vias com pelo menos 10 genes com contagem suficiente. 


\section{Resultados}




\section{RESULTADOS}

\subsection{Coleta do Material}

Na coleta do rúmen dos fetos, bezerros recém-nascidos e bovinos adultos (Figura 1) as posições anatômicas foram exatas às já descritas, não sendo observadas diferenças em relação à literatura.

Figura 1 - Esquema de estômago bovino $(\mathbf{A}, \mathbf{B}$ e $\mathbf{C})$ e foto de fragmento do saco cego caudoventral de rúmen bovino adulto (D). 1- curvatura dorsal; 2- curvatura ventral; 3- saco dorsal; 4- saco ventral; 5- saco cego caudodorsal; 6- saco cego caudoventral; 7- pilares; 8- papilas; 9- cárdia; 10- orifício ruminorreticular; 11- orifício retículo-omasal; 12- lâmina própria-submucosa; 13- túnica muscular.

A

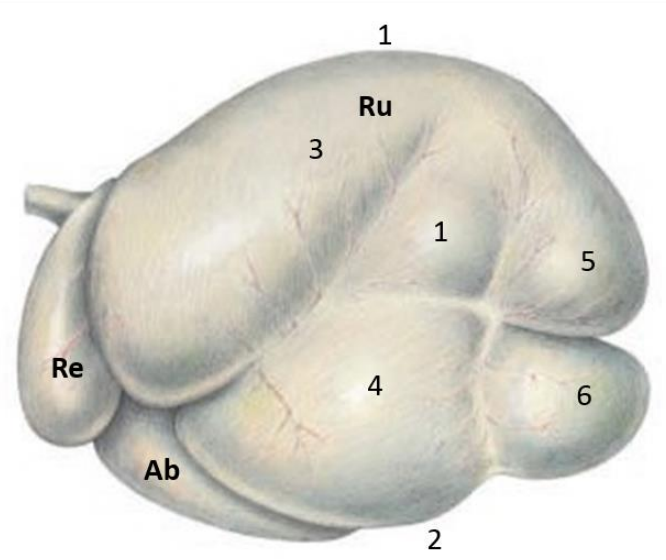

C

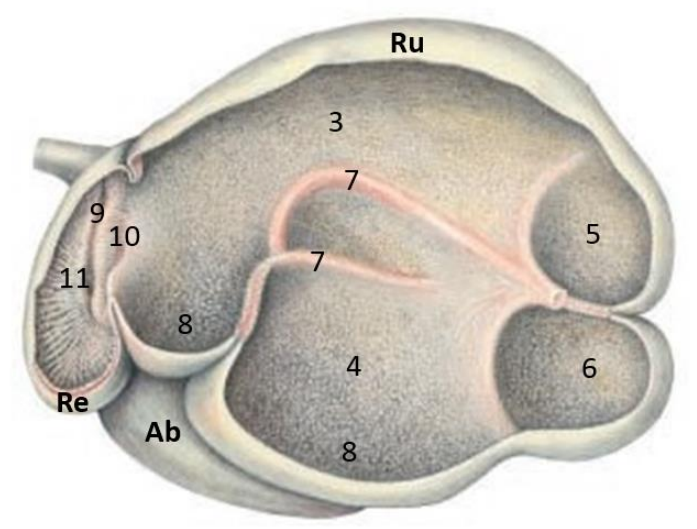

B

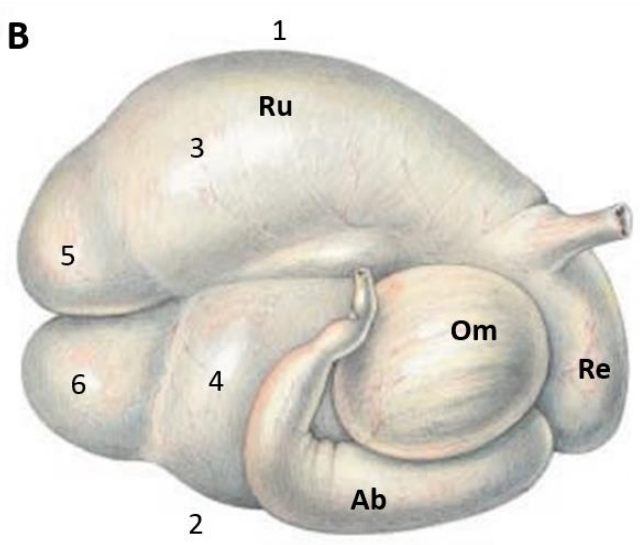

D

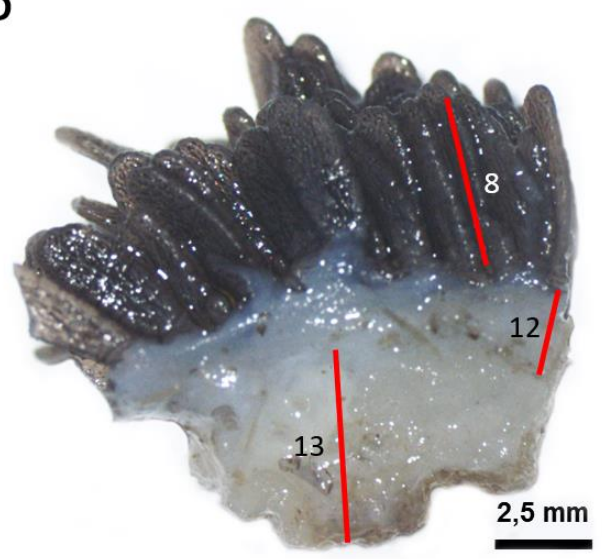

Fonte: Adaptado de BUDRAS \& HABEL, 2003. 


\subsection{Coloração de Hematoxilina-Eosina (HE)}

O tecido epitelial de revestimento do rúmen (Figuras 2 e 3 ) é do tipo pavimentoso estratificado, sendo ele queratinizado no adulto, de espessura variável, formado por quatro camadas de células distintas: basal, espinhosa, granulosa e córnea ou queratinizada, sendo morfologicamente semelhante à epiderme da pele. As células do epitélio formam várias camadas, sendo que as células mais próximas ao tecido conjuntivo são geralmente cúbicas ou prismáticas.

Nos fetos de 110 e 150 dias de desenvolvimento é possível observar que o epitélio do rúmen ainda não se apresenta estratificado, possuindo somente um tipo celular. Essas células são mais alongadas na base do epitélio e cúbicas próximo ao ápice do epitélio (mais próximo ao lúmen do órgão). Além disso, são vacuolizadas e seus núcleos apresentam posição mais periférica, geralmente no ápice celular (Figura 2).

Nos bezerros recém-nascidos, o epitélio ruminal se encontra mais desenvolvido em relação aos fetos, apresentando uma camada mais delgada ao redor das papilas que ainda estão em desenvolvimento. As células do epitélio já apresentam estratificação, porém, ainda não ocorre a queratinização do epitélio ruminal (Figura 3).

Nos adultos, o epitélio encontra-se completamente desenvolvido, sendo ele pavimentoso, estratificado e queratinizado, apresentando as camadas celulares diferenciadas (Figura 3).

O tecido conjuntivo presente entre o epitélio ruminal e a camada muscular pode ser designado como lâmina própria-submucosa (Figuras 2 e 3) (BANKS, 1992). Essa lâmina própria-submucosa é constituída por tecido conjuntivo denso irregular com grande quantidade de fibras elásticas e colágenas, formando o eixo central de cada papila. Os feixes de colágeno do tecido são espessos, ondulados e dispostos de forma irregular.

É possível observar a lâmina própria-submucosa entre a camada basal e a túnica muscular no rúmen de todas as idades estudadas, apresentando espessura variada ao longo do tecido ruminal. Entretanto, nos bezerros recém-nascidos e adultos, a lâmina própriasubmucosa se estende até o interior das papilas (Figuras 2 e 3). Além disso, o rúmen não possui tecido muscular da lâmina mucosa, apresentando em algumas regiões uma condensação de fibras de tecido conjuntivo que não deve ser confundida com tecido muscular.

A camada de tecido muscular observada nos cortes teciduais das idades estudadas é constituída por músculo liso formando as camadas circular interna e longitudinal externa, apresentando-se, também, de espessura variável ao longo do tecido (Figuras $2 \mathrm{e}$ 3). O tecido muscular liso consiste em células ou fibras fusiformes com núcleo central, são revestidas por lâmina basal e mantidas juntas por uma rede muito delicada de fibras reticulares. 
Figura 2 - Coloração de Hematoxilina-Eosina nas porções dorsal (A e C) e ventral (B e D) de fetos de 110 dias (A e B) e 150 dias (C e D) de desenvolvimento. E: epitélio; P: início da formação papilar; CB: camada basal; SM: lâmina própria-submucosa; MI: camada muscular interna circular; ME: camada muscular externa longitudinal; S: túnica serosa. Seta: condensação de fibras do tecido conjuntivo que não deve ser confundida com a muscular da mucosa. Objetiva de 20x e barras de $100 \mu \mathrm{m}$.

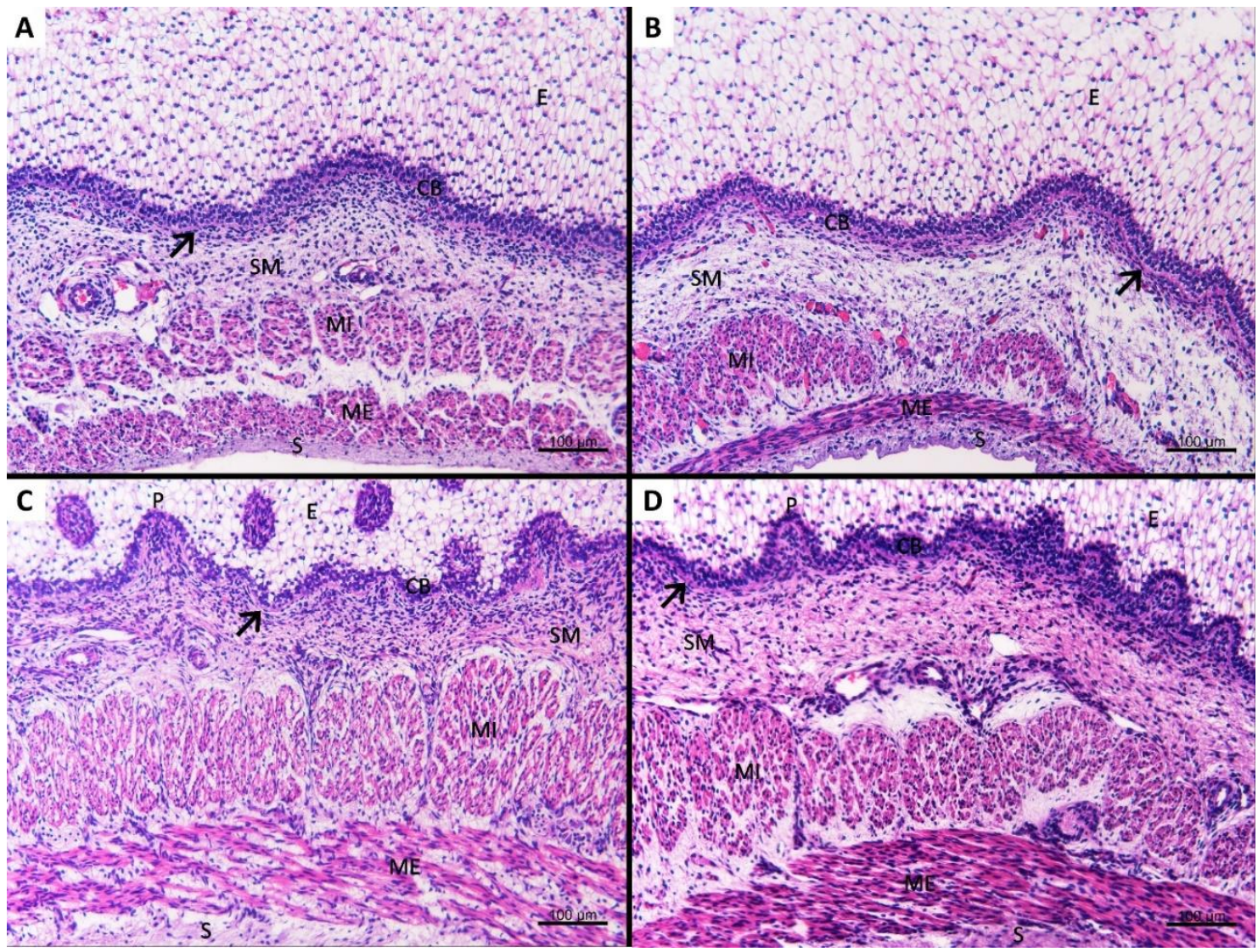

Fonte: Ferrão, J. S. P. (2018). 
Figura 3 - Coloração de Hematoxilina-Eosina nas porções dorsal (A e C) e ventral (B e D) de bezerros recém-nascidos (A e B) e bovinos adultos ( $\mathbf{C}$ e $\mathbf{D})$. L: lúmen ruminal; E: epitélio escamoso estratificado (queratinizado); P: papila; SM: lâmina própria-submucosa; MI: camada muscular interna circular; ME: camada muscular externa longitudinal; S: túnica serosa. Seta: camada basal. A, C e D: objetiva de 4x e barras de $500 \mu \mathrm{m}$. B: objetiva de $10 x$ e barra de $200 \mu \mathrm{m}$.

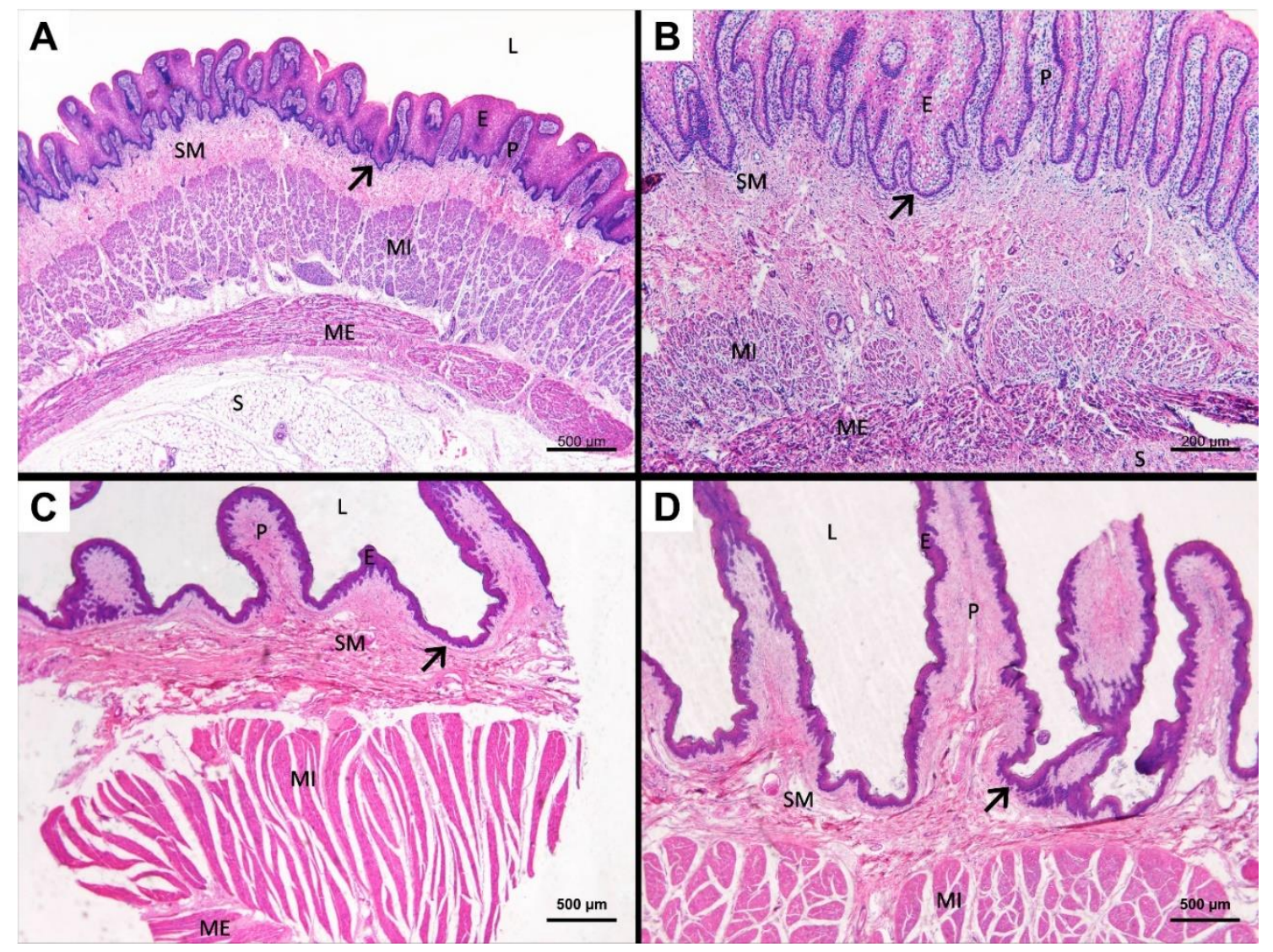

Fonte: Ferrão, J. S. P. (2018).

\subsection{Morfometria ruminal}

O rúmen possui um epitélio escamoso estratificado queratinizado, constituído por diferentes camadas celulares, sendo elas, a camada basal, a camada espinhosa, a camada granulosa e a camada córnea.

A camada basal é a camada mais profunda, formada por uma única fileira de células cúbicas a colunares, também sendo chamada de camada germinativa, pois nela ocorrem mitoses celulares, responsáveis pela criação e manutenção das camadas mais superiores.

A camada espinhosa, localizada superiormente à camada basal, é formada por duas ou mais colunas de células com processos espinhosos (queratinócitos), sendo essas 
células provenientes da camada basal, das quais sofreram modificações para a formação do tecido epitelial. A camada granulosa, mais superficial à camada espinhosa, possui várias camadas celulares, também de queratinócitos, que ao mudarem para essa camada mais superficial, começam a produzir grânulos de queratina no seu citoplasma. A camada córnea, a mais superficial, é composta por várias fileiras de células queratinizadas mortas (queratinócitos repletos de queratina e anucleados).

Devido às essas divisões do epitélio ruminal, foram realizadas mensurações das camadas basais dos fetos, bezerros recém-nascidos e bovinos adultos separadamente do restante do epitélio ruminal (camadas espinhosa, granulosa e córnea), uma vez que a camada basal possui importância diferente em relação ao epitélio, devido ao seu alto teor de mitoses para suprir as camadas mais superficiais com suas células filhas (queratinócitos). Assim, foram realizadas mensurações da camada basal e do epitélio ruminal (camada espinhosa, camada granulosa e camada córnea). Além disso, somente nos bovinos adultos pode-se identificar a camada córnea.

Quando realizada a morfometria da camada basal entre as porções dorsal e ventral do rúmen nas diferentes idades estudadas, não ocorreu diferença estatística significativa para os fetos e bezerros recém-nascidos (média entre as porções dorsal e ventral = $31,877 \mu \mathrm{m}$ e $\mathrm{p}=0,3029$ para os fetos de 110 dias de desenvolvimento; média entre as porções dorsal e ventral $=39,711 \mu \mathrm{m}$ e $\mathrm{p}=0,8477$ para os fetos de 150 dias de desenvolvimento; e média entre as porções dorsal e ventral $=13,518 \mu \mathrm{m}$ e $\mathrm{p}=0,4744$ para os bezerros recém-nascidos). No entanto, na comparação entre essas porções no bovino adulto, ocorreu diferença estatística significativa (média da porção dorsal $=55,159 \mu \mathrm{m}$, média da porção ventral $=70,128 \mu \mathrm{m}$ e $\mathrm{p}=0,0013)$.

Na comparação da camada basal das porções dorsal e ventral entre as diferentes idades estudadas, observou-se que ocorreu diferença estatística significativa $(p<0,001)$, sendo a camada basal do rúmen dos adultos foi a mais espessa e a camada basal ruminal dos bezerros recém-nascidos foi a mais delgada (Figura 4 e Tabela 5). 
Figura 4 - Mensuração da camada basal das porções dorsal e ventral do rúmen de fetos bovinos, bezerros recém-nascidos e bovinos adultos. Fetos e bezerros representados pelas médias entre suas porções dorsal e ventral. Bovinos adultos com a representação da média da porção dorsal e da porção ventral. Letras diferentes indicam diferença estatística significativa $(\mathrm{p}<0,001)$ entre as diferentes idades e $(*)$ indica diferença estatística significativa $(\mathrm{p}=0,0013)$ entre as porções dorsal e ventral no adulto.

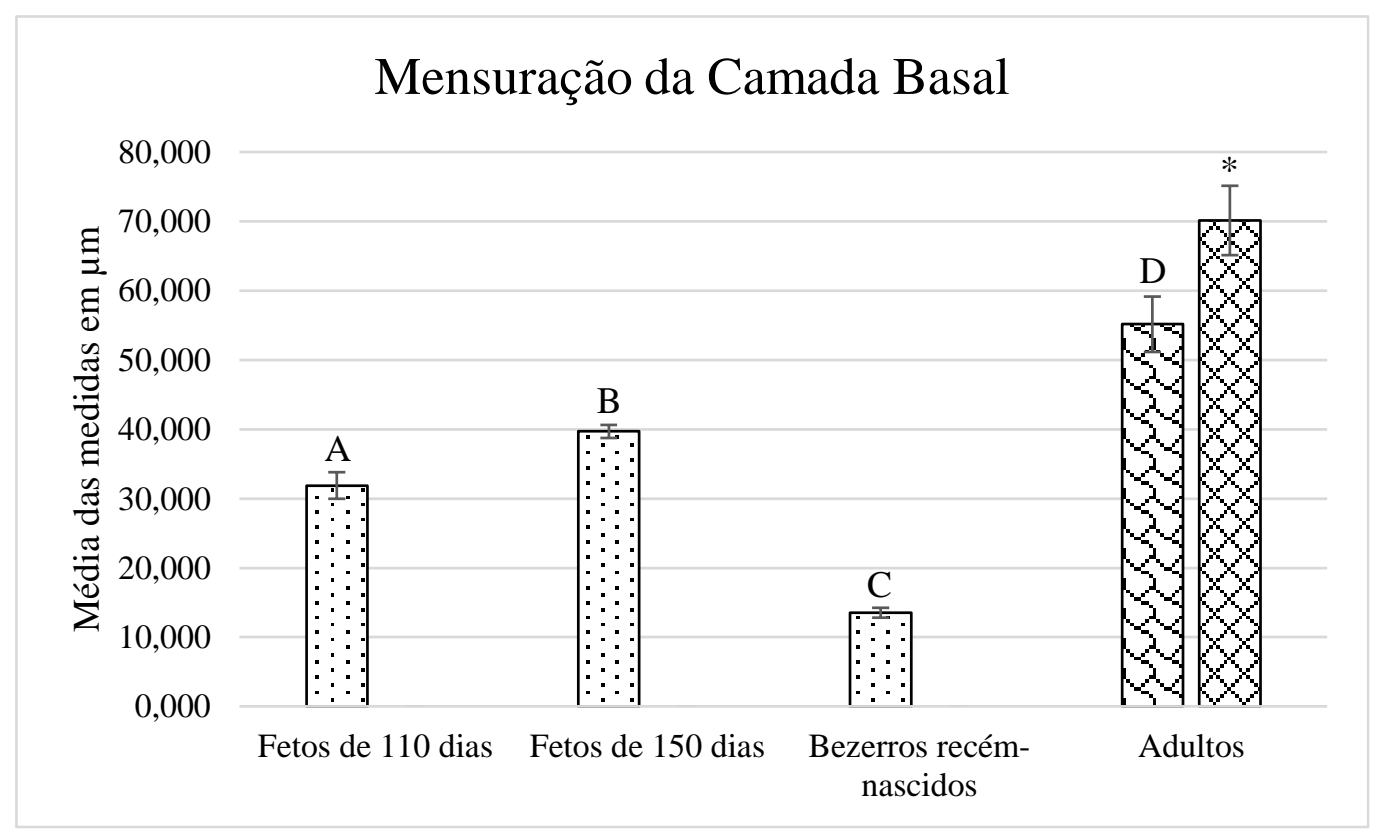

Fonte: Ferrão, J. S. P. (2018).

Tabela 5 - Médias \pm desvio padrão das mensurações realizadas na camada basal dos fetos, bezerros recém-nascidos e bovinos adultos. Medidas em $\mu \mathrm{m}$. Letras iguais indicam sem diferença estatística significante $(\mathrm{p} \geq 0,05)$ e letras diferentes indicam diferença estatística significativa $(\mathrm{p}<0,001)$.

\begin{tabular}{cccccc}
\hline $\begin{array}{c}\text { Região do } \\
\text { tecido }\end{array}$ & $\begin{array}{c}\text { Porção do } \\
\text { Rúmen }\end{array}$ & Fetos 110 dias & Fetos 150 dias & $\begin{array}{c}\text { Bezerros recém- } \\
\text { nascidos }\end{array}$ & Bovinos adultos \\
\hline Camada & Dorsal & $32,7 \pm 1,9^{\mathrm{a}}$ & $39,8 \pm 0,9^{\mathrm{b}}$ & $13,3 \pm 0,7^{\mathrm{c}}$ & $55,2 \pm 7,1^{\mathrm{d}}$ \\
Basal & Ventral & $31,1 \pm 1,9^{\mathrm{a}}$ & $39,7 \pm 1,3^{\mathrm{b}}$ & $13,8 \pm 0,9^{\mathrm{c}}$ & $70,1 \pm 8,4^{\mathrm{e}}$ \\
\hline
\end{tabular}

Dessa maneira, pode-se inferir que a camada basal sofre mudanças consideráveis conforme ocorre o desenvolvimento epitelial ruminal, demonstrando seus diferentes graus de importância em cada fase de desenvolvimento nas idades estudadas. Enquanto fetos, as médias das espessuras da camada basal se mantêm relativamente constantes (ainda que diferentes), mostrando a necessidade da formação do tecido epitelial do rúmen para o nascimento do animal. Enquanto bezerro, como o animal não utiliza o rúmen na sua alimentação, somente o abomaso (alimentação à base de leite), a espessura da camada basal diminui, uma vez que não há a necessidade da manutenção desse epitélio que não está sendo utilizado. Uma vez adulto, em pleno funcionamento ruminal, a espessura da camada basal volta a crescer, tornando-se superior a encontrada nos fetos, pois há grande 
necessidade de manutenção tecidual do rúmen devido ao seu desgaste diário pela ingestão de alimentos sólidos e abrasão da superfície tecidual ruminal.

Quando realizada a morfometria do epitélio entre as porções dorsal e ventral do rúmen nas diferentes idades estudadas, observou-se que não ocorreu diferença estatística significativa entre as porções para cada idade (média entre as porções dorsal e ventral = $375,365 \mu \mathrm{m}$ e $\mathrm{p}=0,1075$ para os fetos de 110 dias de desenvolvimento; média entre as porções dorsal e ventral $=754,935 \mu \mathrm{m}$ e $\mathrm{p}=0,0676$ para os fetos de 150 dias de desenvolvimento; média entre as porções dorsal e ventral $=386,569 \mu \mathrm{m}$ e $\mathrm{p}=0,1695$ para os bezerros recém-nascidos; média entre as porções dorsal e ventral $=16,411 \mu \mathrm{m}$ e $\mathrm{p}=0,3990$ para os bovinos adultos).

No entanto, pode-se observar que ocorreram diferenças significativas $(\mathrm{p}<0,001)$ quando a comparação foi feita entre as diferentes idades para as mensurações dessas porções, não ocorrendo diferença estatística significativa $(\mathrm{p}>0,05)$ apenas entre os fetos de 110 dias de desenvolvimento e os bezerros recém-nascidos. Os fetos de 150 dias apresentaram seu epitélio mais espesso que as outras idades, enquanto que o epitélio encontrado nos fetos de 110 dias de desenvolvimento e nos bezerros recém-nascidos foi semelhante. Além disso, o epitélio encontrado nos bovinos adultos foi o mais delgado em comparação às outras idades estudadas (Figura 5 e Tabela 6).

Figura 5 - Mensuração do epitélio das porções dorsal e ventral do rúmen de fetos bovinos, bezerros recémnascidos e bovinos adultos, representados pelas médias entre suas porções dorsal e ventral. Letras iguais indicam sem diferença estatística significante $(\mathrm{p} \geq 0,05)$ e letras diferentes indicam diferença estatística significativa $(\mathrm{p}<0,001)$.

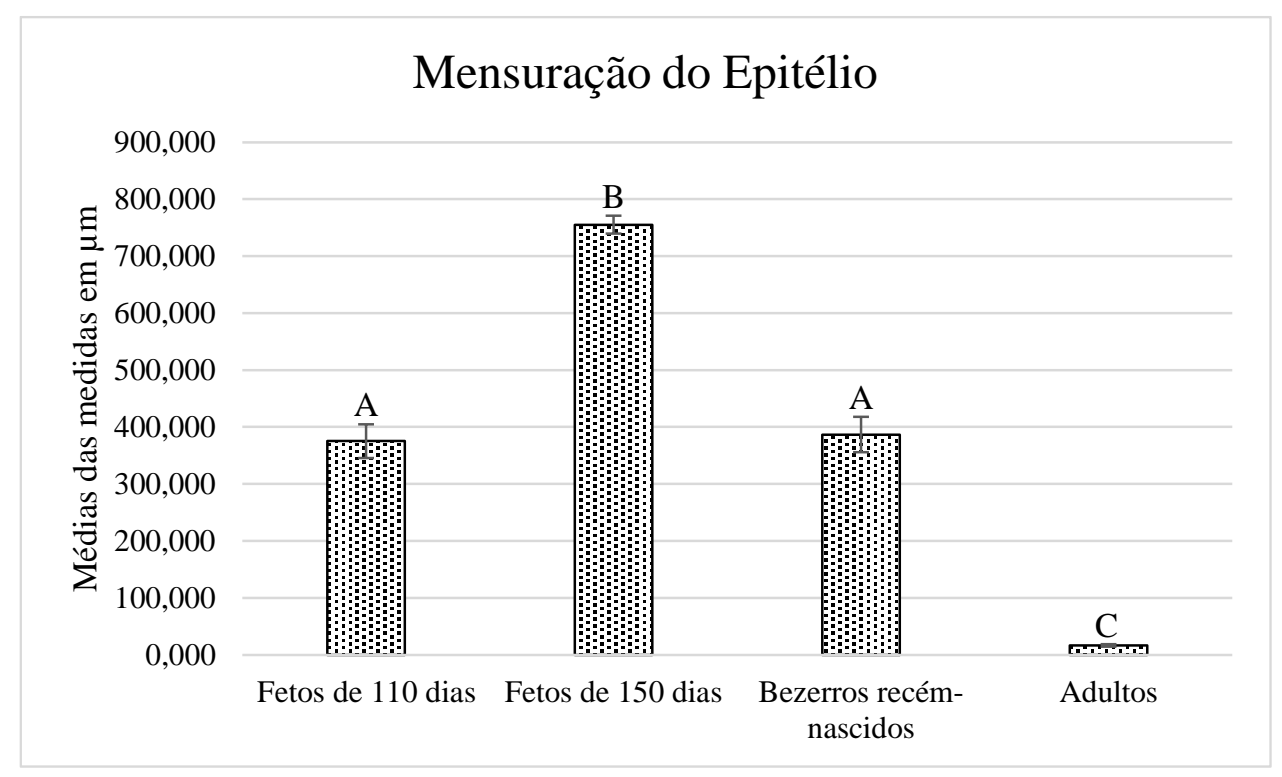

Fonte: Ferrão, J. S. P. (2018). 
Tabela 6 - Médias \pm desvio padrão das mensurações realizadas no epitélio dos fetos, bezerros recémnascidos e bovinos adultos. Medidas em $\mu \mathrm{m}$. Letras iguais indicam sem diferença estatística significante $(\mathrm{p} \geq 0,05)$ e letras diferentes indicam diferença estatística significativa $(\mathrm{p}<0,001)$.

\begin{tabular}{cccccc}
\hline $\begin{array}{c}\text { Região do } \\
\text { tecido }\end{array}$ & $\begin{array}{c}\text { Porção do } \\
\text { Rúmen }\end{array}$ & Fetos 110 dias & Fetos 150 dias & $\begin{array}{c}\text { Bezerros recém- } \\
\text { nascidos }\end{array}$ & Bovinos adultos \\
\hline Camada & Dorsal & $295,1 \pm 39,1^{\mathrm{a}}$ & $769,8 \pm 8,3^{\mathrm{b}}$ & $363,1 \pm 23,3^{\mathrm{a}}$ & $16,7 \pm 3,0^{\mathrm{c}}$ \\
Basal & Ventral & $371,0 \pm 50,3^{\mathrm{a}}$ & $740,1 \pm 15,7^{\mathrm{b}}$ & $410,1 \pm 31,1^{\mathrm{a}}$ & $16,1 \pm 2,4^{\mathrm{c}}$ \\
\hline
\end{tabular}

Com esses resultados, pode-se inferir que o epitélio sofre mudanças significativas conforme ocorre o desenvolvimento ruminal, demonstrando seus diferentes graus de importância em cada fase de desenvolvimento nas idades estudadas. Nos fetos de 150 dias de desenvolvimento, as médias das espessuras do epitélio são maiores que as médias encontradas nos fetos de 110 dias, podendo este ser um indicativo de preparação do epitélio para sua futura utilização. No entanto, os bezerros apresentaram médias similares aos fetos de 110 dias, indicando que esse epitélio ainda não utilizado para a digestão e fermentação alimentar apenas necessita de uma manutenção para manter esse epitélio preparado para uso. Nos bovinos adultos, o rúmen em pleno funcionamento ruminal apresenta espessura epitelial menor que nas outras idades estudadas, podendo ser um indicativo do uso constante e diário desse revestimento ruminal, que sofre abrasões contínuas pelo material ingerido. Além disso, a presença das papilas ruminais completamente desenvolvidas, aumenta a superfície de contato do epitélio com a ingesta, com o líquido ruminal e com os gases presentes no rúmen, tornando maior a absorção de nutrientes essenciais para a manutenção calórica e fisiológica do animal e para o próprio epitélio ruminal.

Em relação à mensuração das papilas das porções dorsal e ventral do rúmen, não foi possível realizar a mensuração nos fetos de 110 dias de desenvolvimento, uma vez que as papilas ainda não iniciaram o seu desenvolvimento (Figura 6 e Tabela 7).

$\mathrm{Na}$ comparação entre as outras idades estudadas pode-se observar que ocorreu uma diferença estatística significativa $(\mathrm{p}<0,0001)$ entre as diferentes porções estudadas, sendo que os bovinos adultos apresentaram médias superiores, demonstrando a conclusão do desenvolvimento e da formação papilar. Além disso, também foi possível observar que, apesar de não haver diferença $(\mathrm{p} \geq 0,05)$ entre as porções do rúmen no feto de 150 dias de desenvolvimento, os bezerros recém-nascidos e os bovinos adultos apresentaram diferenças significativas ( $\mathrm{p}<0,0001$ para os bezerros e $\mathrm{p}=0,0060$ para os adultos) no tamanho das papilas quando comparadas as duas porções ruminais, sendo que a porção ventral apresentou papilas de tamanhos superiores às encontradas na porção dorsal (Figura 6 e Tabela 7). 
Figura 6 - Mensuração das papilas nas porções dorsal e ventral do rúmen de fetos bovinos, bezerros recémnascidos e bovinos adultos. Os fetos de 150 dias estão representados pela média entre a porção dorsal e ventral do rúmen. Letras iguais indicam sem diferença estatística significante $(p \geq 0,05)$ e letras diferentes indicam diferença estatística significativa $(\mathrm{p}<0,0001)$.

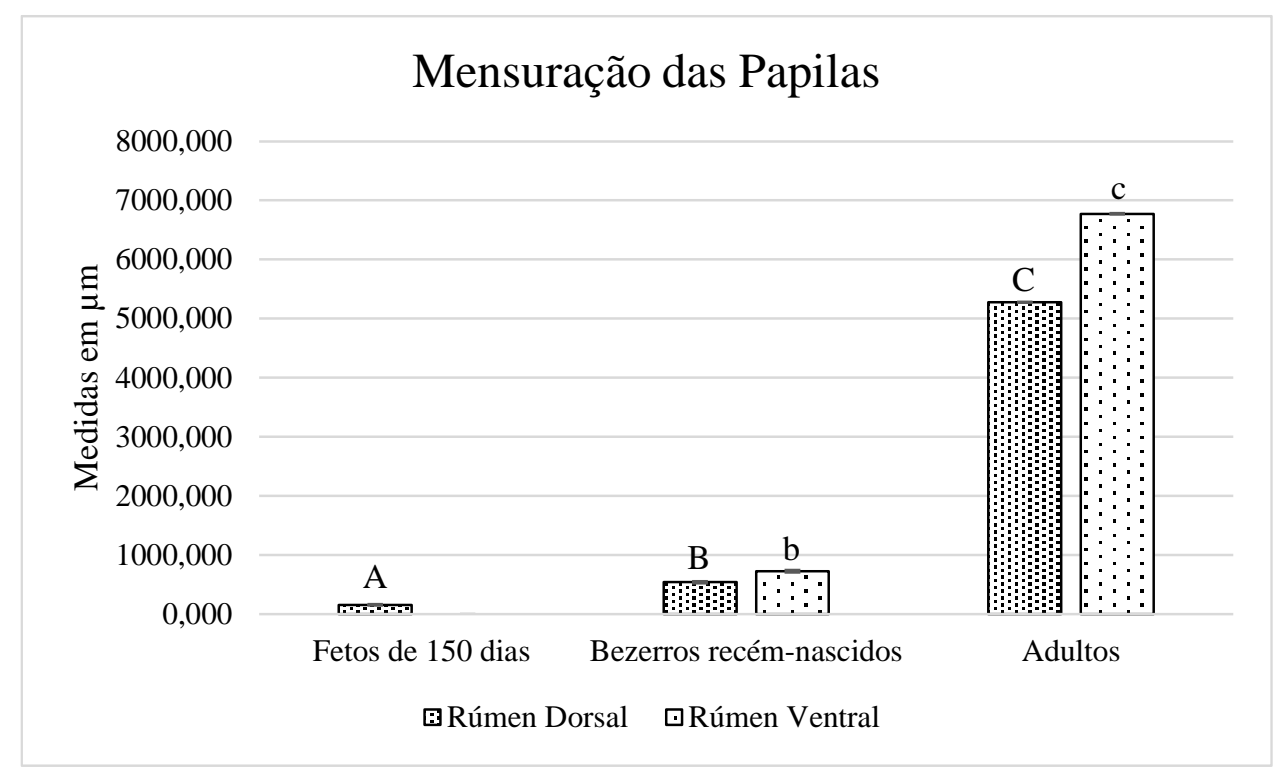

Fonte: Ferrão, J. S. P. (2018).

Tabela 7 - Médias \pm desvio padrão das mensurações realizadas nas papilas dos fetos, bezerros recémnascidos e bovinos adultos. Medidas em $\mu \mathrm{m}$. Letras iguais indicam sem diferença estatística significante $(\mathrm{p} \geq 0,05)$ e letras diferentes indicam diferença estatística significativa $(\mathrm{p}<0,0001)$.

\begin{tabular}{ccccc}
\hline $\begin{array}{c}\text { Região do } \\
\text { tecido }\end{array}$ & $\begin{array}{c}\text { Porção do } \\
\text { Rúmen }\end{array}$ & Fetos 150 dias & $\begin{array}{c}\text { Bezerros recém- } \\
\text { nascidos }\end{array}$ & Bovinos adultos \\
\hline \multirow{2}{*}{ Papilas } & Dorsal & $162,4 \pm 8,2^{\mathrm{a}}$ & $537,7 \pm 16,3^{\mathrm{b}}$ & $5276,0 \pm 6,4^{\mathrm{d}}$ \\
& Ventral & $149,1 \pm 10,1^{\mathrm{a}}$ & $723,3 \pm 22,1^{\mathrm{c}}$ & $6771,0 \pm 10,6^{\mathrm{e}}$ \\
\hline
\end{tabular}

\subsection{Microscopia Eletrônica de Transmissão (MET)}

Os cortes ultrafinos dos rumens dos fetos bovinos e dos bezerros recém-nascidos foram observados ao microscópio eletrônico de transmissão (Figura 5), podendo ser observadas as células do tecido epitelial, da camada basal e do tecido conjuntivo.

Nos fetos de 110 dias e 150 dias de desenvolvimento a camada basal encontra-se mais espessa e pouco organizada, com núcleos grandes disformes ou ligeiramente cilíndricos e citoplasma denso, enquanto que nos bezerros recém-nascidos a camada basal 
encontra-se mais organizada e com menor quantidade de camadas, porém caracteristicamente semelhante, em ambas as regiões do rúmen (Figura 7).

Em relação ao epitélio, os fetos apresentaram células maiores quando comparadas com as células encontradas nos bezerros recém-nascidos. Além disso, os núcleos apresentam-se descentralizados e o citoplasma possui aspecto menos denso que o encontrado nas células basais (Figura 7). Além disso, o epitélio, em ambas as porções do rúmen e para todas as idades estudadas, apresentou grande quantidade de desmossomos nas membranas celulares (Figura 8). A lâmina própria-submucosa observada em ambas as porções e em todas as idades é densa não modelada, contendo fibras colágenas, elásticas e reticulares (Figura 7). 
Figura 7 - Microscopia Eletrônica de Transmissão (MET). Cortes ultrafinos do rúmen de fetos bovinos e bezerros recém-nascidos em historresina. Nas micrografias é possível observar tecido epitelial (E), camada basal (CB) e lâmina própria submucosa (SM). As imagens A e B representam, respectivamente, cortes da porção dorsal e ventral do rúmen de feto de 110 dias de desenvolvimento. As imagens $\mathbf{C}$ e $\mathbf{D}$ representam, respectivamente, cortes da porção dorsal e ventral do rúmen de feto de 150 dias de desenvolvimento. As imagens $\mathbf{E}$ e $\mathbf{F}$ representam, respectivamente, cortes da porção dorsal e ventral do rúmen de bezerro recémnascido. A seta indica região queratinizada. A com barra de $5 \mu \mathrm{m}$ e as demais micrografias com barras de $10 \mu \mathrm{m}$.
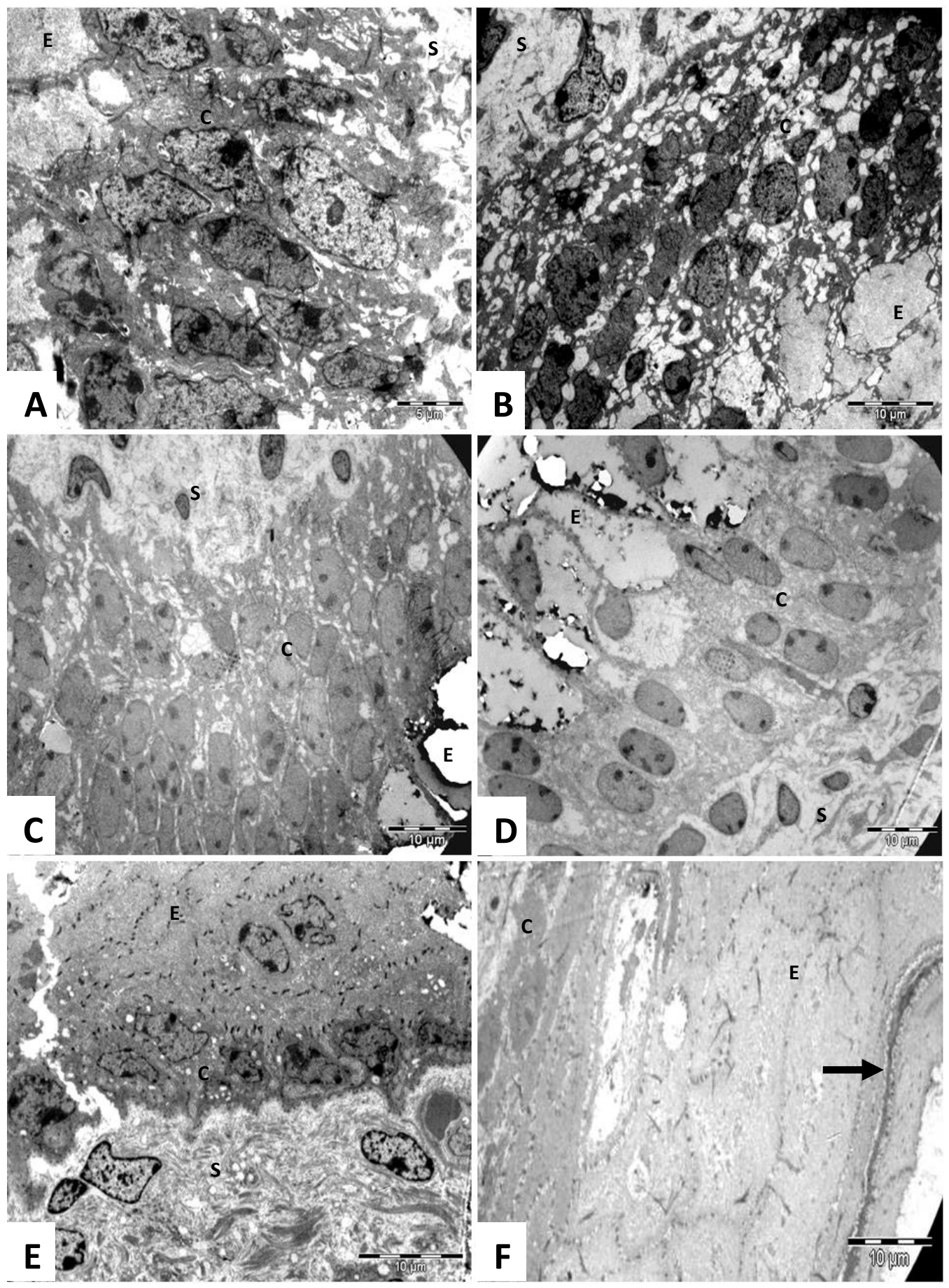

Fonte: Ferrão, J. S. P. (2018). 
Figura 8 - Microscopia Eletrônica de Transmissão (MET). Corte ultrafino (historresina) do rúmen de bezerros recém-nascidos. Na micrografia é possível observar tecido epitelial (E) e desmossomos (setas). Barra de $2 \mu \mathrm{m}$.

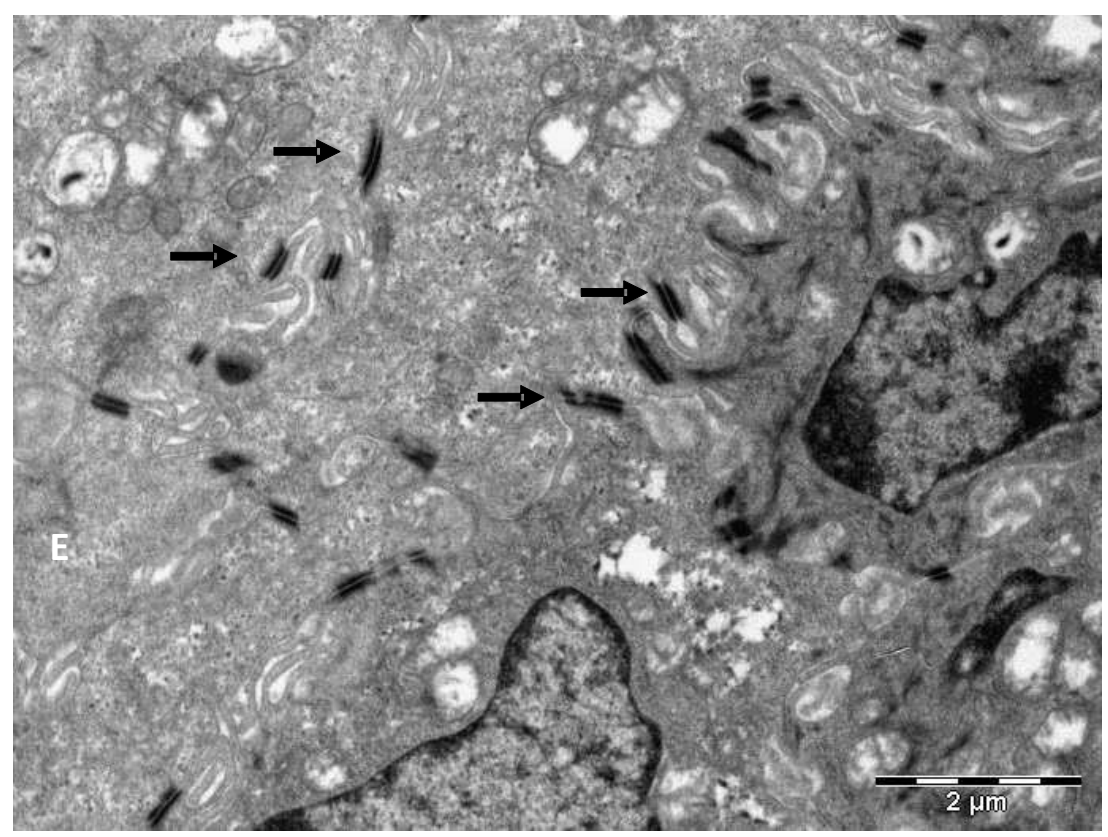

Fonte: Ferrão, J. S. P. (2018).

\subsection{Imunofluorescência}

Após realização das imunofluorescências, foram realizadas fotomicrografias e análises dos resultados.

Ao analisar a imunofluorescência para marcação da Cx26, foi observada uma marcação citoplasmática muito fraca em membrana basal nos fetos de 110 e 150 dias de desenvolvimento (Figura 9), tanto na porção dorsal como na ventral do rúmen. No entanto, no epitélio ocorreu uma marcação mais intensa em região mais apical (mais próxima ao lúmen), com marcação de membrana plasmática e citoplasma, nos fetos de 110 dias, em ambas as porções do rúmen, sendo mais intensa na porção dorsal. Nos fetos de 150 dias, no epitélio ocorreu marcação de membrana plasmática, sendo ela homogênea ao longo de todo o epitélio, em ambas as porções ruminais (Figura 10). Além disso, na porção dorsal ruminal do feto de 150 dias de desenvolvimento parece ocorrer marcação nuclear das células da camada basal e do epitélio (Figuras 9 e 10).

Em relação aos bezerros recém-nascidos, a marcação da camada basal encontrada na porção dorsal do rúmen foi mais intensa que a encontrada na porção ventral, sendo ela sempre citoplasmática (Figura 9). No entanto, ambas as porções ruminas apresentaram marcação mais intensa em epitélio, principalmente em região mais 
apical (mais próxima ao lúmen), sendo ela em membrana plasmática. Também é possível observar marcação citoplasmática no epitélio, sendo ela mais intensa na porção dorsal do rúmen (Figura 10).

Quando observada a marcação no tecido adulto para a Cx26, na porção dorsal ruminal, quase não houve marcação, tanto em camada basal (citoplasmática) quanto no epitélio (citoplasma e membrana plasmática). No entanto, na porção ventral do rúmen pode ser observada uma ligeira marcação no citoplasma das células (Figuras 9 e 10).

Ao analisar a imunofluorescência para marcação da Cx32, foi observada uma boa marcação em citoplasma das células da camada basal em ambas as idades de fetos estudadas, sendo a mesma mais intensa no feto de 150 dias. Na porção ventral do rúmen, a marcação citoplasmática na camada basal é menos intensa quando compara com a porção dorsal para o feto de 110 dias, porém, o contrário pode ser observado para o feto 150 dias. Além disso, no feto de 150 dias de desenvolvimento parece haver, também, marcação nuclear ou perinuclear para essa conexina nas células da camada basal. (Figura 11). Em relação ao epitélio, ocorre marcação de membranas plasmáticas, sendo que a mesma se fez mais intensa na região mais apical (mais próxima ao lúmen) no feto de 110 dias, para ambas as porções do rúmen. No entanto, para o feto de 150 dias, a marcação, também em membrana plasmática, apresenta-se mais homogênea ao longo do epitélio, em ambas as porções do rúmen (Figura 12).

Para os bezerros recém-nascidos, há marcação intensa citoplasmática na camada basal da porção dorsal do rúmen, sendo que essa intensidade diminui drasticamente na porção ventral ruminal (Figura 11). Em relação ao epitélio, a marcação é mais intensa em região mais apical (mais próxima ao lúmen), sendo ela em citoplasma e, principalmente, em membrana plasmática, em ambas as porções ruminais (Figura 12).

Em relação à marcação nas porções ruminais de bovinos adultos, ocorreu marcação em citoplasma na camada basal e no tecido epitelial, sendo ela de, aproximadamente, mesma intensidade em ambas as porções ruminais. Além disso, também parece haver a marcação nuclear ou perinuclear de células da camada basal e do epitélio (Figuras 11 e 12). 
Figura 9 - Localização da Conexina 26 (marcação por FITC) no epitélio ruminal de fetos bovinos, bezerros recém-nascidos e bovinos adultos. $14 \mathrm{~A}$ e $14 \mathrm{~B}$, epitélio da porção dorsal e da porção ventral do rúmen de fetos de 110 dias de desenvolvimento, mostrando a presença da Cx26 na camada epitelial basal. $14 \mathrm{~A}$ com figura menor representando o controle negativo. $14 \mathrm{C}$ e $14 \mathrm{D}$, epitélio da porção dorsal e da porção ventral do rúmen de fetos de 150 dias de desenvolvimento, mostrando a presença da Cx26 na camada epitelial basal. $14 E$ e $14 \mathrm{~F}$, epitélio da porção dorsal e da porção ventral do rúmen de bezerros recémnascidos, mostrando a presença da Cx26 na camada epitelial basal. $14 G$ e $14 \mathrm{H}$, epitélio da porção dorsal e da porção ventral do rúmen de bovinos adultos, mostrando a presença da Cx26 na camada epitelial basal. E: epitélio; P: papila; CB: camada basal; SM: lâmina própria-submucosa; Q: queratina.
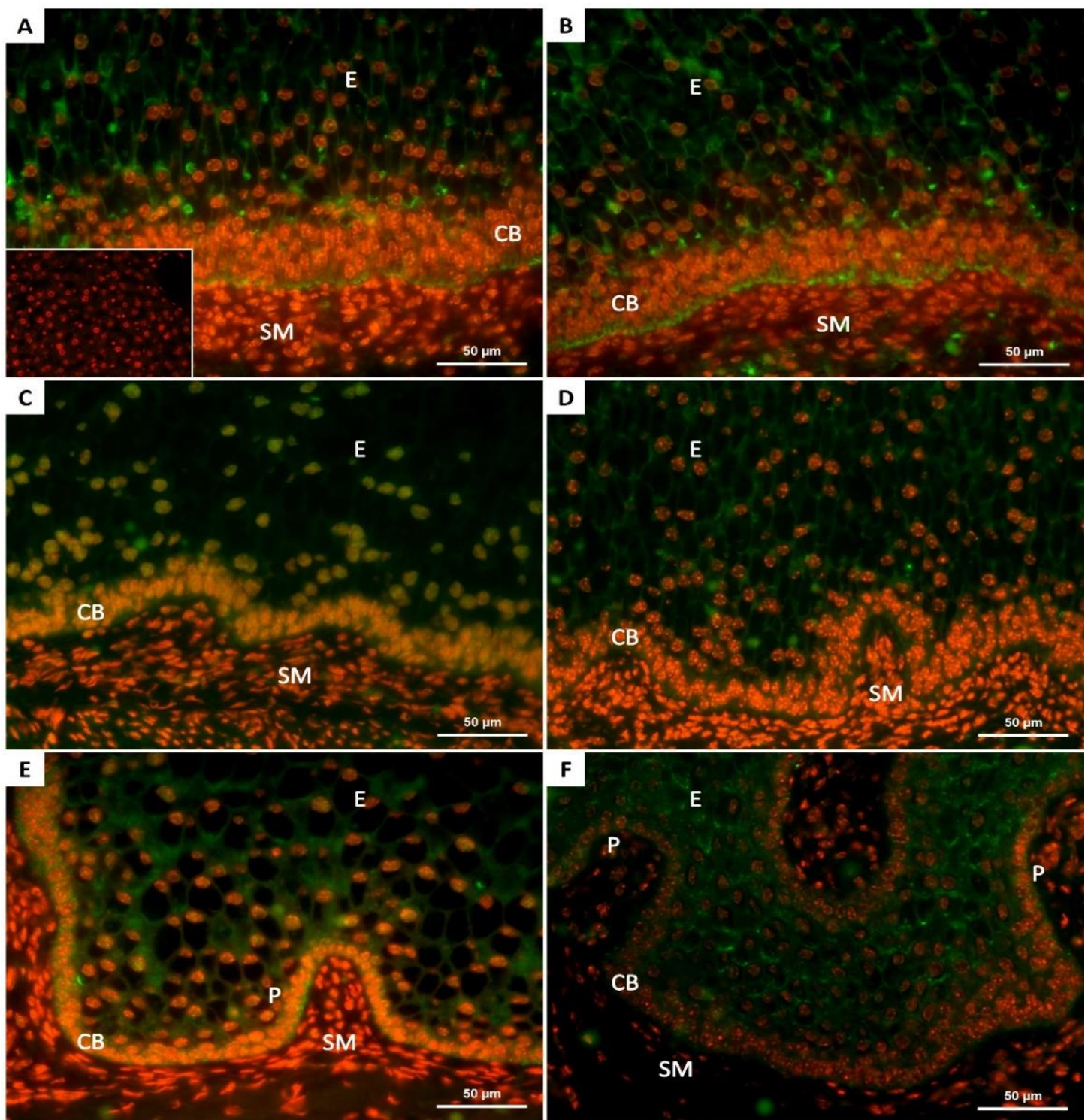

$\mathrm{CB}$

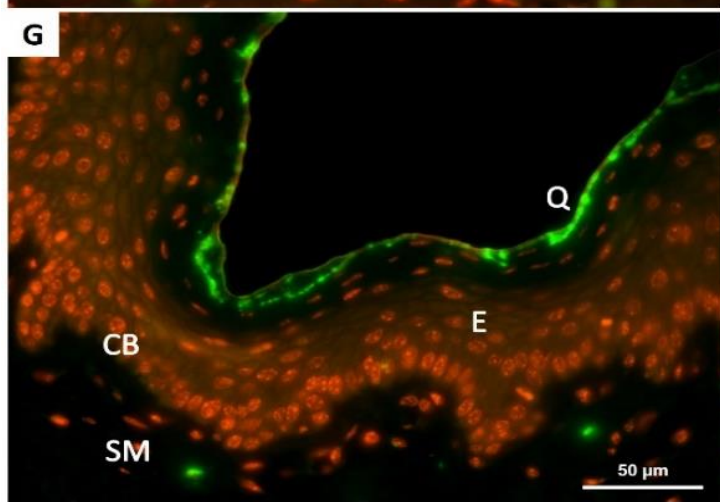

SM

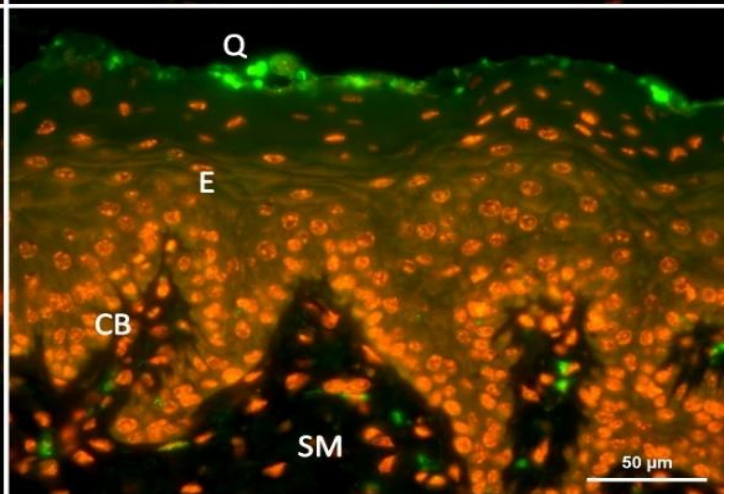

Fonte: Ferrão, J. S. P. (2018). 
Figura 10 - Localização da Conexina 26 (marcação por FITC) no epitélio ruminal de fetos bovinos, bezerros recém-nascidos e bovinos adultos. $14 \mathrm{~A}$ e $14 \mathrm{~B}$, epitélio da porção dorsal e da porção ventral do rúmen de fetos de 110 dias de desenvolvimento, mostrando a presença da Cx26 nas células do epitélio escamoso estratificado. $14 \mathrm{~A}$ com figura menor representando o controle negativo. $14 \mathrm{C}$ e $14 \mathrm{D}$, epitélio da porção dorsal e da porção ventral do rúmen de fetos de 150 dias de desenvolvimento, mostrando a presença da Cx26 nas células do epitélio escamoso estratificado. $14 E$ e $14 F$, epitélio da porção dorsal e da porção ventral do rúmen de bezerros recém-nascidos, mostrando a presença da Cx26 nas células do epitélio escamoso estratificado. $14 G$ e $14 H$, epitélio da porção dorsal e da porção ventral do rúmen de bovinos adultos, mostrando a presença da Cx26 nas células do epitélio escamoso estratificado. E: epitélio; P: papila; CB: camada basal; SM: lâmina própriasubmucosa; Q: queratina.

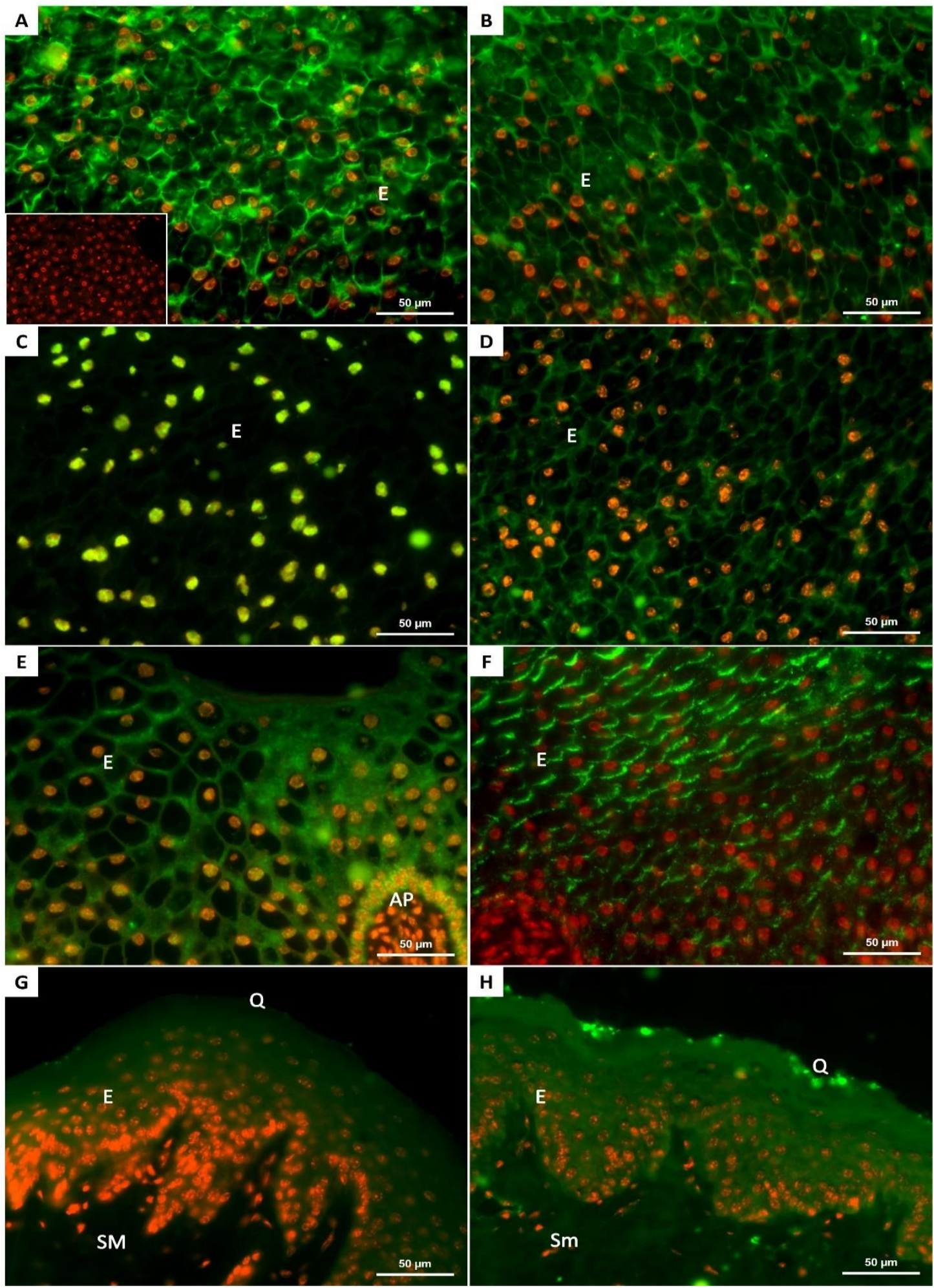

Fonte: Ferrão, J. S. P. (2018). 
Figura 11 - Localização da Conexina 32 (marcação por FITC) no epitélio ruminal de fetos bovinos, bezerros recém-nascidos e bovinos adultos. $14 \mathrm{~A}$ e 14B, epitélio da porção dorsal e da porção ventral do rúmen de fetos de 110 dias de desenvolvimento, mostrando a presença da Cx32 na camada epitelial basal. $14 \mathrm{~A}$ com figura menor representando o controle negativo. $14 \mathrm{C}$ e $14 \mathrm{D}$, epitélio da porção dorsal e da porção ventral do rúmen de fetos de 150 dias de desenvolvimento, mostrando a presença da Cx32 na camada epitelial basal. $14 E$ e $14 \mathrm{~F}$, epitélio da porção dorsal e da porção ventral do rúmen de bezerros recémnascidos, mostrando a presença da Cx32 na camada epitelial basal. $14 G$ e $14 H$, epitélio da porção dorsal e da porção ventral do rúmen de bovinos adultos, mostrando a presença da Cx32 na camada epitelial basal. E: epitélio; P: papila; CB: camada basal; SM: lâmina própria-submucosa; Q: queratina.

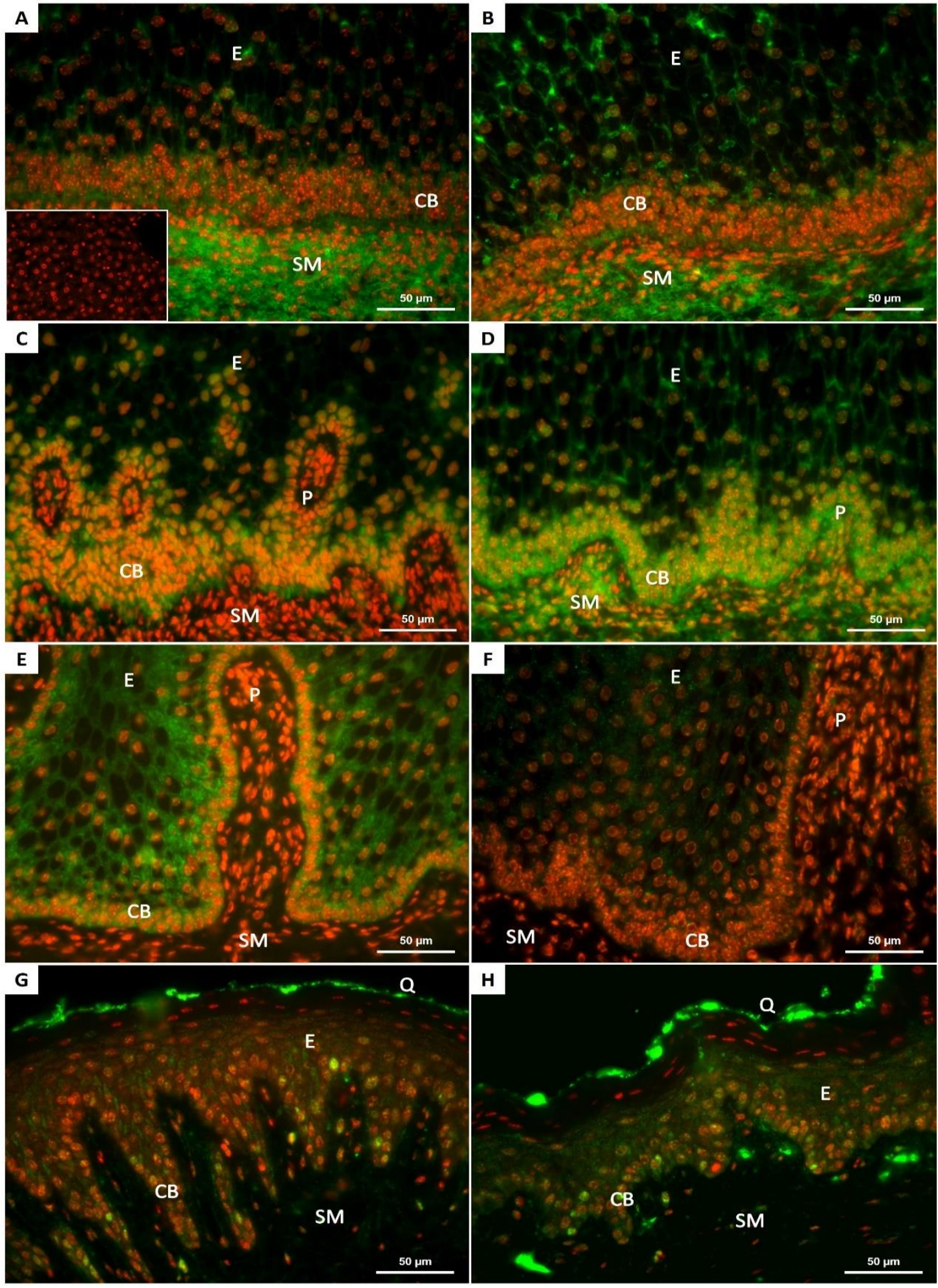

Fonte: Ferrão, J. S. P. (2018). 
Figura 12 - Localização da Conexina 32 (marcação por FITC) no epitélio ruminal de fetos bovinos, bezerros recém-nascidos e bovinos adultos. $14 \mathrm{~A}$ e $14 \mathrm{~B}$, epitélio da porção dorsal e da porção ventral do rúmen de fetos de 110 dias de desenvolvimento, mostrando a presença da Cx32 nas células do epitélio escamoso estratificado. $14 \mathrm{~A}$ com figura menor representando o controle negativo. $14 \mathrm{C}$ e $14 \mathrm{D}$, epitélio da porção dorsal e da porção ventral do rúmen de fetos de 150 dias de desenvolvimento, mostrando a presença da Cx32 nas células do epitélio escamoso estratificado. $14 E$ e $14 F$, epitélio da porção dorsal e da porção ventral do rúmen de bezerros recém-nascidos, mostrando a presença da Cx32 nas células do epitélio escamoso estratificado. 14G e 14H, epitélio da porção dorsal e da porção ventral do rúmen de bovinos adultos, mostrando a presença da Cx32 nas células do epitélio escamoso estratificado. E: epitélio; P: papila; CB: camada basal; SM: lâmina própriasubmucosa; Q: queratina.
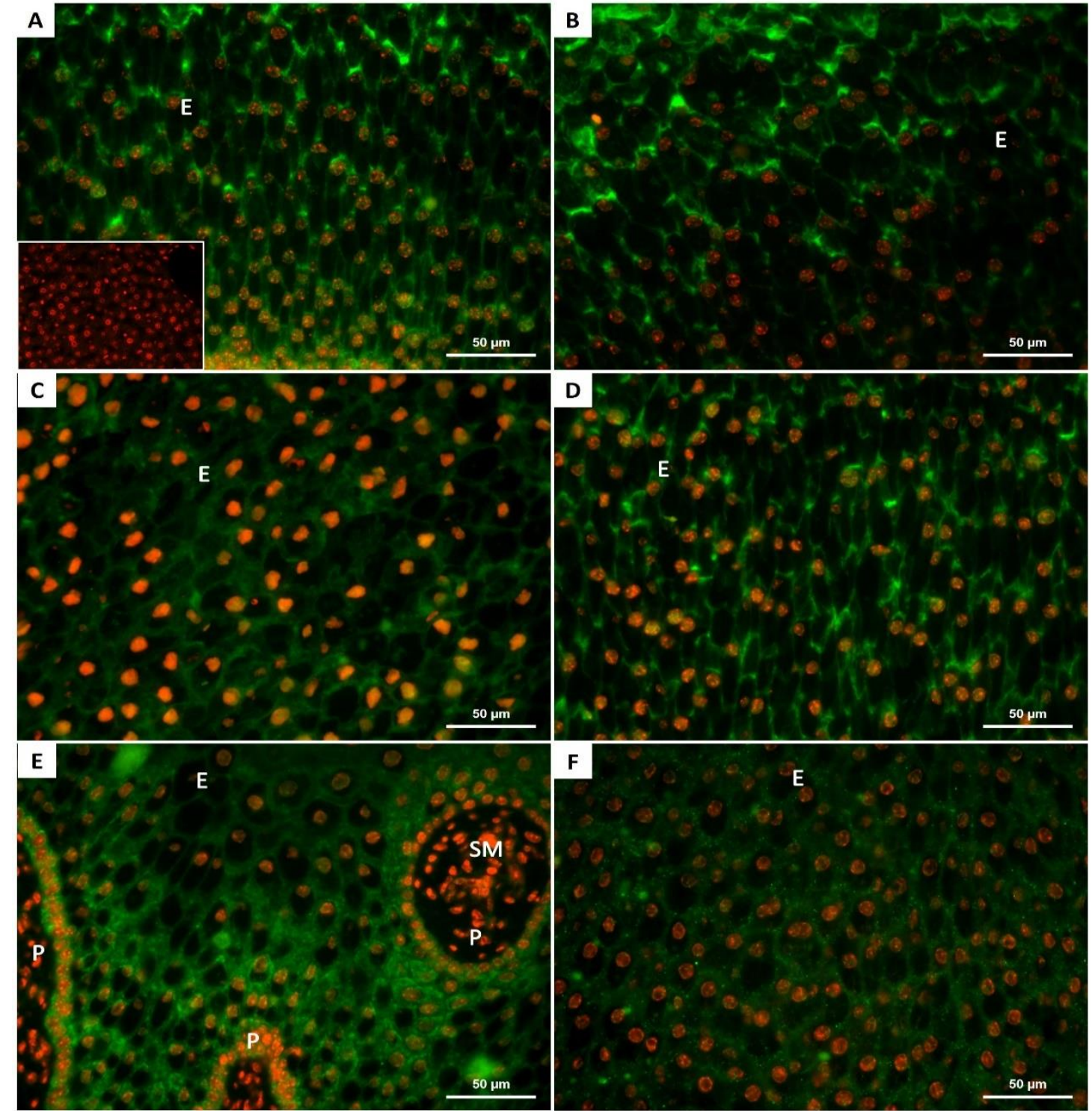

$\mathrm{F}$

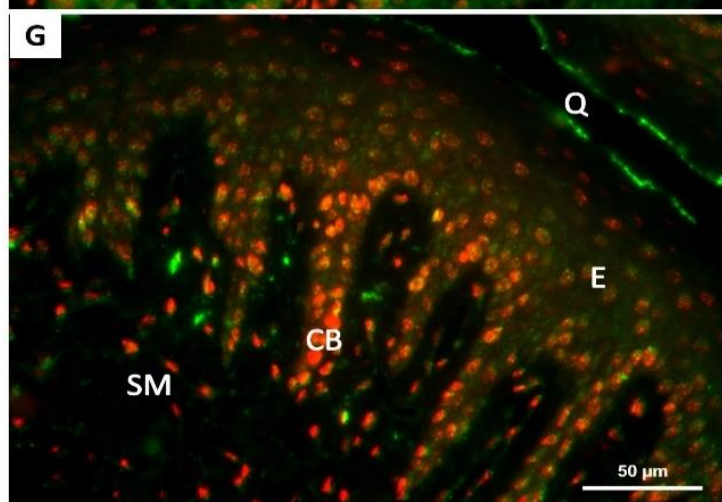

$50 \mu \mathrm{m}$

H

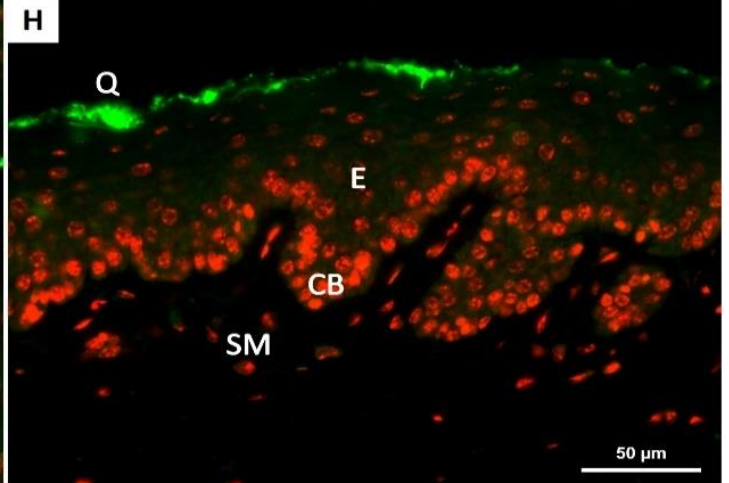

Fonte: Ferrão, J. S. P. (2018). 
Na marcação para a Cx40, ocorreu uma intensa marcação citoplasmática nas células da camada basal dos fetos bovinos em ambas as porções do rúmen. No epitélio, a marcação foi mais intensa em região mais apical (mais próxima ao lúmen) em ambas as idades de feto estudadas e em ambas as porções ruminais. No entanto, a porção dorsal do feto de 110 dias apresentou marcação mais intensa quando comparada com o feto de 150 dias e com a porção ventral de ambas as idades. Além disso, principalmente nas porções dorsais do rúmen, aparenta haver marcação nuclear ou perinuclear das células da camada basal e do epitélio (Figuras 13 e 14).

Em relação à marcação nos bezerros recém-nascidos, ocorreu marcação citoplasmática das células da camada basal, sendo ela mais intensa na porção ventral do rúmen. No epitélio, a marcação foi mais intensa em região apical, sendo ela em membrana plasmática e em citoplasma. Assim como ocorreu na camada basal, a marcação foi mais intensa na porção ventral ruminal (Figuras 13 e 14).

Na marcação do tecido ruminal dos bovinos adultos, houve maior intensidade de marcação na porção dorsal do rúmen, porém ambas as porções apresentaram marcação intensa em citoplasma e membrana plasmática, esta última no epitélio. Também ocorreu uma aparente marcação nuclear ou perinuclear em células da camada basal (Figuras 13 e 14).

Em relação à marcação da $\mathrm{Cx} 43$, o citoplasma das células da camada basal e a membrana plasmática de região apical (mais próxima ao lúmen) do epitélio da porção dorsal do feto de 110 dias apresentaram marcação, sendo que a da camada basal foi mais intensa. No entanto, a marcação foi quase inexistente na porção ventral do feto de 110 dias e em ambas as porções ruminais do feto de 150 dias de desenvolvimento (Figuras 15 e 16).

Nos bezerros recém-nascidos, a marcação para essa conexina foi ligeira na camada basal, enquanto que no epitélio ela foi intensa e homogênea, com marcação de membrana plasmática e citoplasma, em ambas as porções do rúmen (Figuras 15 e 16).

A marcação do tecido ruminal de bovinos adultos apresentou-se no citoplasma de células da camada basal e de células do epitélio, além de ocorrer intensa marcação em membrana plasmática das células do epitélio (Figuras 15 e 16). 
Figura 13 - Localização da Conexina 40 (marcação por FITC) no epitélio ruminal de fetos bovinos, bezerros recém-nascidos e bovinos adultos. $14 \mathrm{~A}$ e 14B, epitélio da porção dorsal e da porção ventral do rúmen de fetos de 110 dias de desenvolvimento, mostrando a presença da $\mathrm{Cx} 40$ na camada epitelial basal. $14 \mathrm{~A}$ com figura menor representando o controle negativo. $14 \mathrm{C}$ e $14 \mathrm{D}$, epitélio da porção dorsal e da porção ventral do rúmen de fetos de 150 dias de desenvolvimento, mostrando a presença da Cx40 na camada epitelial basal. $14 E$ e $14 F$, epitélio da porção dorsal e da porção ventral do rúmen de bezerros recémnascidos, mostrando a presença da Cx40 na camada epitelial basal. $14 G$ e $14 \mathrm{H}$, epitélio da porção dorsal e da porção ventral do rúmen de bovinos adultos, mostrando a presença da $\mathrm{Cx} 40$ na camada epitelial basal. E: epitélio; P: papila; CB: camada basal; SM: lâmina própria-submucosa; Q: queratina.
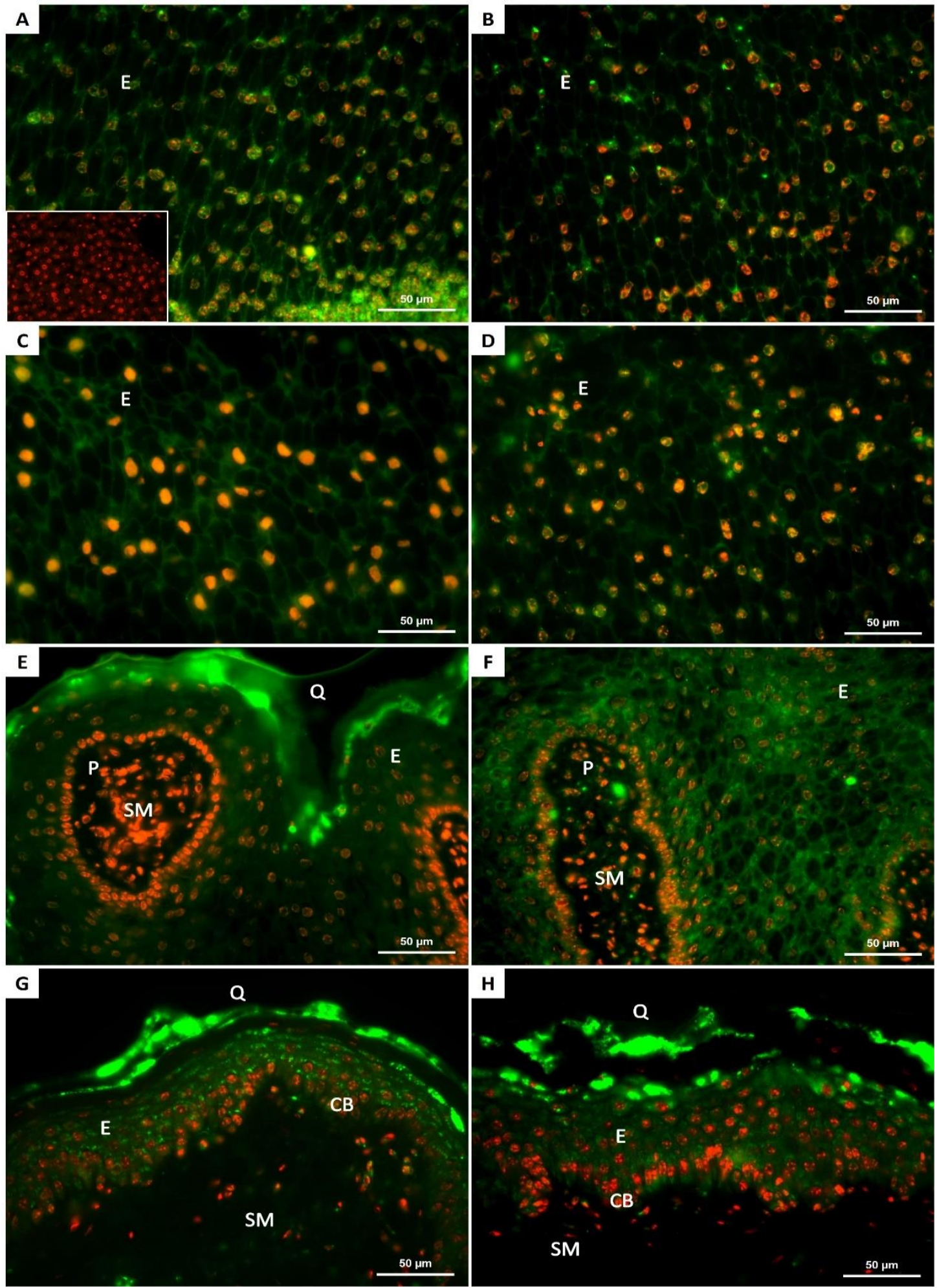

Fonte: Ferrão, J. S. P. (2018). 
Figura 14 - Localização da Conexina 40 (marcação por FITC) no epitélio ruminal de fetos bovinos, bezerros recém-nascidos e bovinos adultos. $14 \mathrm{~A}$ e $14 \mathrm{~B}$, epitélio da porção dorsal e da porção ventral do rúmen de fetos de 110 dias de desenvolvimento, mostrando a presença da Cx40 nas células do epitélio escamoso estratificado. $14 \mathrm{~A}$ com figura menor representando o controle negativo. $14 \mathrm{C}$ e $14 \mathrm{D}$, epitélio da porção dorsal e da porção ventral do rúmen de fetos de 150 dias de desenvolvimento, mostrando a presença da Cx 40 nas células do epitélio escamoso estratificado. $14 E$ e $14 F$, epitélio da porção dorsal e da porção ventral do rúmen de bezerros recém-nascidos, mostrando a presença da $\mathrm{Cx} 40$ nas células do epitélio escamoso estratificado. $14 G$ e $14 H$, epitélio da porção dorsal e da porção ventral do rúmen de bovinos adultos, mostrando a presença da Cx40 nas células do epitélio escamoso estratificado. E: epitélio; P: papila; CB: camada basal; SM: lâmina própriasubmucosa; Q: queratina.

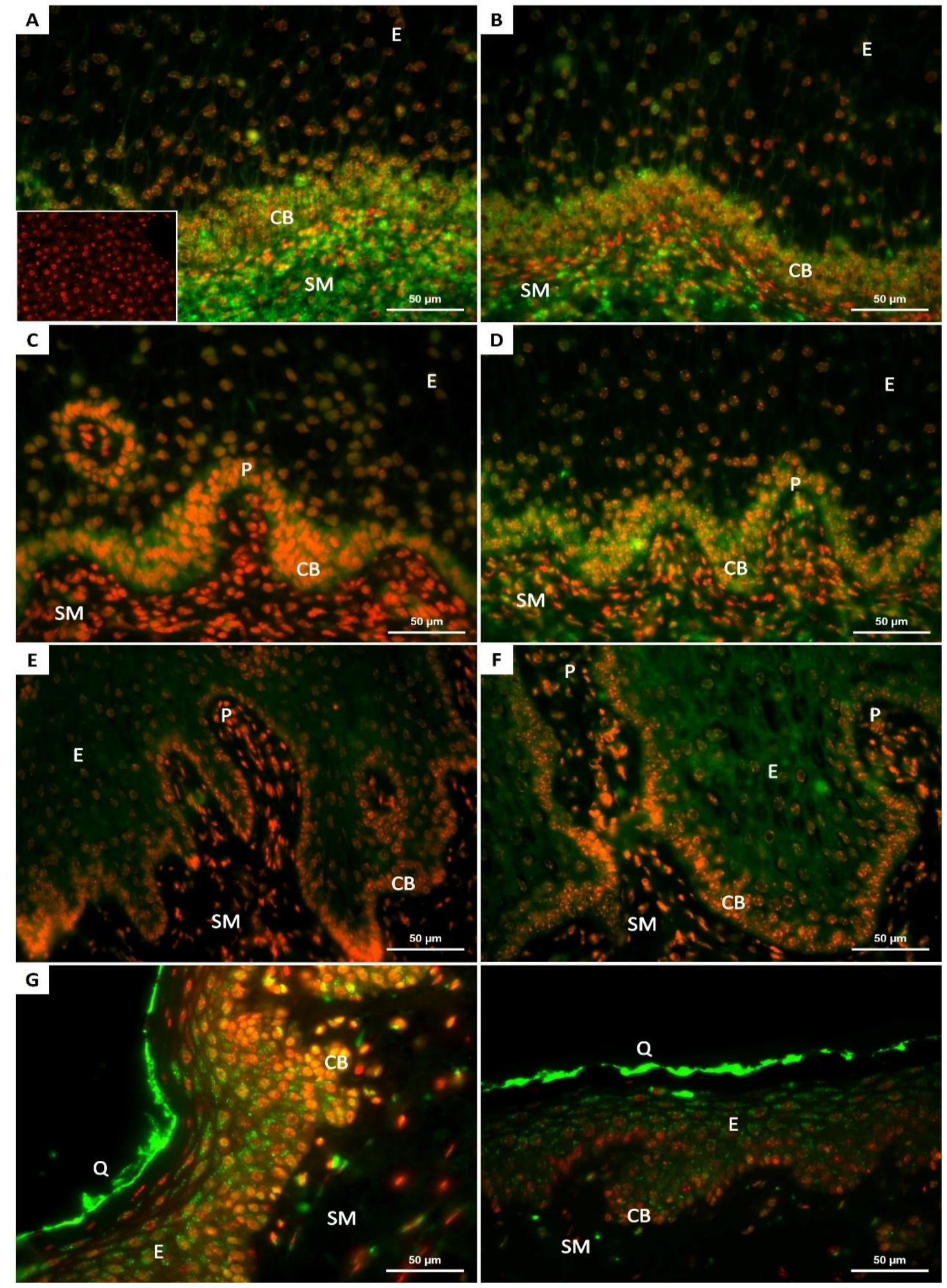

Fonte: Ferrão, J. S. P. (2018). 
Figura 15 - Localização da Conexina 43 (marcação por FITC) no epitélio ruminal de fetos bovinos, bezerros recém-nascidos e bovinos adultos. $14 \mathrm{~A}$ e 14B, epitélio da porção dorsal e da porção ventral do rúmen de fetos de 110 dias de desenvolvimento, mostrando a presença da $\mathrm{Cx} 43$ na camada epitelial basal. $14 \mathrm{~A}$ com figura menor representando o controle negativo. $14 \mathrm{C}$ e $14 \mathrm{D}$, epitélio da porção dorsal e da porção ventral do rúmen de fetos de 150 dias de desenvolvimento, mostrando a presença da Cx43 na camada epitelial basal. $14 E$ e $14 F$, epitélio da porção dorsal e da porção ventral do rúmen de bezerros recémnascidos, mostrando a presença da $\mathrm{Cx} 43$ na camada epitelial basal. $14 G$ e $14 H$, epitélio da porção dorsal e da porção ventral do rúmen de bovinos adultos, mostrando a presença da Cx43 na camada epitelial basal. E: epitélio; P: papila; CB: camada basal; SM: lâmina própria-submucosa; Q: queratina.

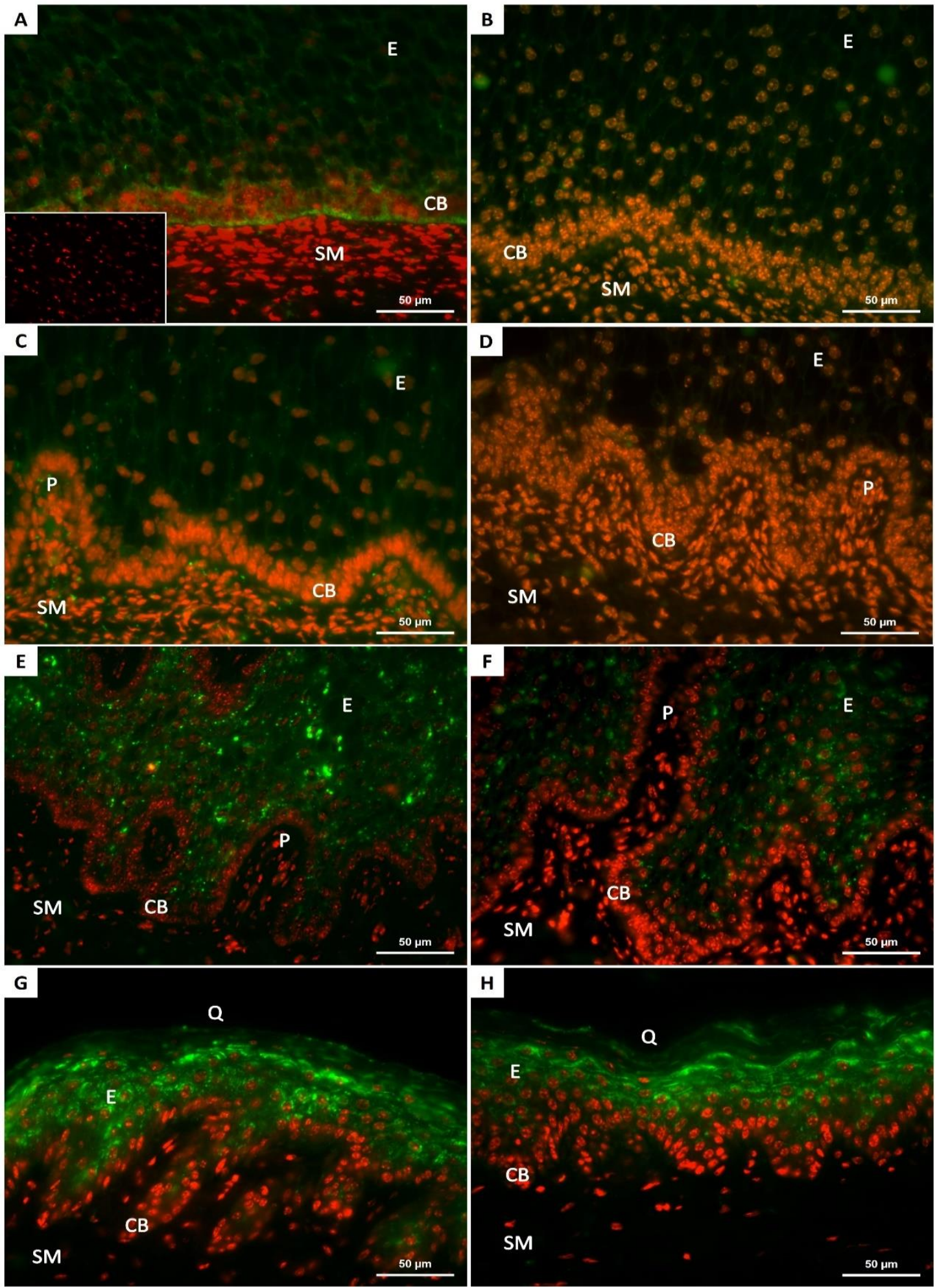

Fonte: Ferrão, J. S. P. (2018). 
Figura 16 - Localização da Conexina 43 (marcação por FITC) no epitélio ruminal de fetos bovinos, bezerros recém-nascidos e bovinos adultos. $14 \mathrm{~A}$ e $14 \mathrm{~B}$, epitélio da porção dorsal e da porção ventral do rúmen de fetos de 110 dias de desenvolvimento, mostrando a presença da Cx43 nas células do epitélio escamoso estratificado. $14 \mathrm{~A}$ com figura menor representando o controle negativo. $14 \mathrm{C}$ e $14 \mathrm{D}$, epitélio da porção dorsal e da porção ventral do rúmen de fetos de 150 dias de desenvolvimento, mostrando a presença da Cx 43 nas células do epitélio escamoso estratificado. $14 E$ e $14 F$, epitélio da porção dorsal e da porção ventral do rúmen de bezerros recém-nascidos, mostrando a presença da $\mathrm{Cx} 43$ nas células do epitélio escamoso estratificado. $14 G$ e $14 H$, epitélio da porção dorsal e da porção ventral do rúmen de bovinos adultos, mostrando a presença da Cx43 nas células do epitélio escamoso estratificado. E: epitélio; P: papila; CB: camada basal; SM: lâmina própriasubmucosa; Q: queratina.

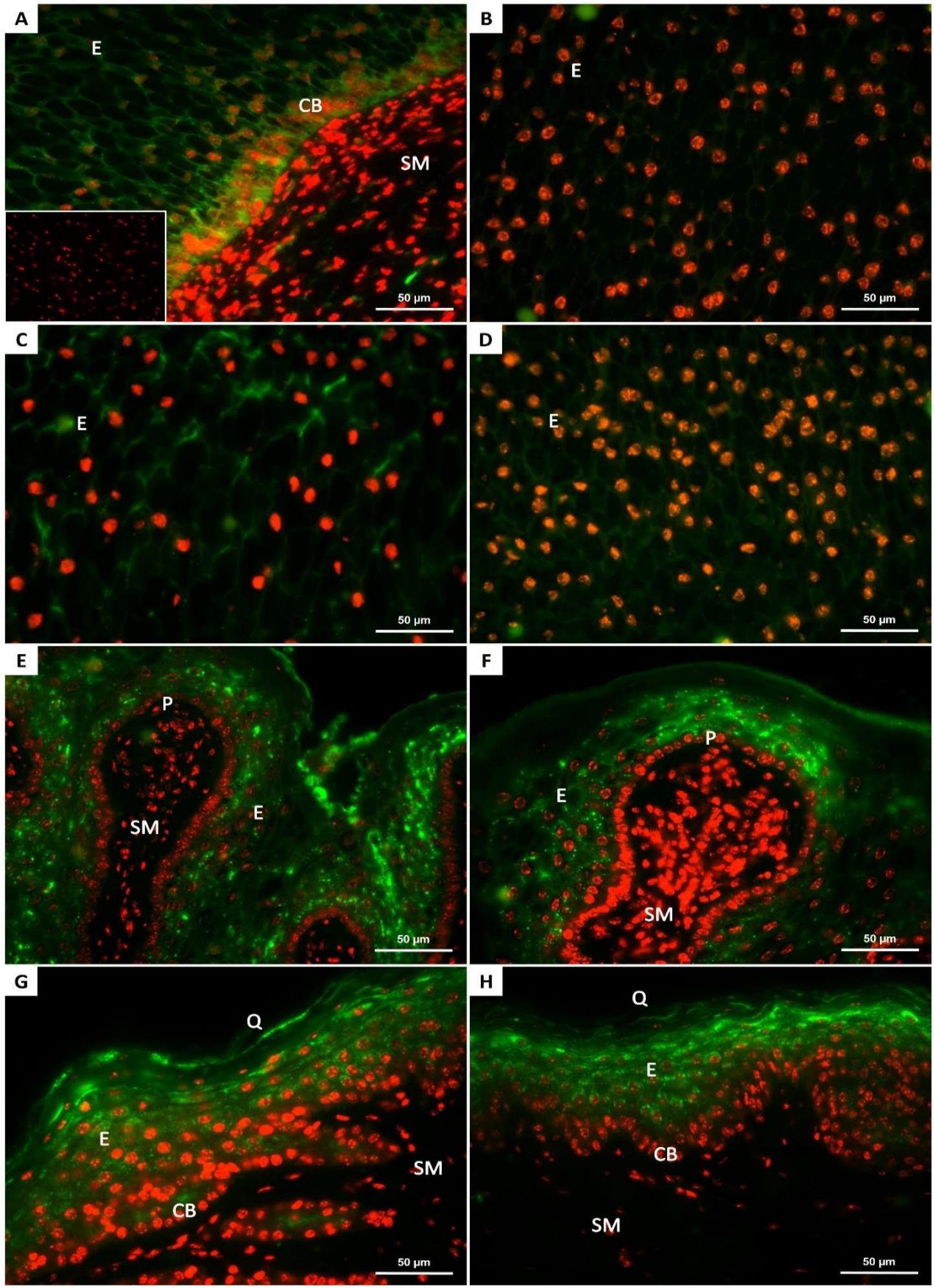

Fonte: Ferrão, J. S. P. (2018). 
Ao analisar a imunofluorescência para marcação da E-caderina, foi observada uma intensa marcação em membrana celular das células basais nos fetos de 110 e 150 dias de desenvolvimento (Figura 17), tanto na porção dorsal como na ventral do rúmen. Além disso, também se observou ligeira marcação citoplasmática das células basais nos fetos de 110 dias de desenvolvimento, sendo essa mesma marcação mais acentuada nos fetos de 150 dias de gestação, para ambas as regiões do rúmen. Nos fetos de 150 dias, na região ventral do rúmen ocorreu uma aparente marcação nuclear das células basais. No entanto, a marcação de membrana celular das células basais encontrada nos bezerros recém-nascidos mostrou-se mais sutil quando comparada às marcações encontradas nos fetos, sendo que a marcação da porção ventral dos bezerros foi mais acentuada que a marcação encontrada nessa mesma idade na porção dorsal ruminal. Em relação aos bovinos adultos, quase não houve marcação das membranas celulares basais em ambas as porções ruminais, sendo a marcação mais intensa nas camadas intermedirias do epitélio (Figura 17). Observou-se, então, que os fetos apresentaram marcação mais intensa em camada basal quando comparados com as outras idades estudadas. 
Figura 17: Localização da E-caderina (marcação por FITC) no epitélio ruminal de fetos bovinos, bezerros recém-nascidos e bovinos adultos. $14 \mathrm{~A}$ e $14 \mathrm{~B}$, epitélio da porção dorsal e da porção ventral do rúmen de fetos de 110 dias de desenvolvimento, mostrando a presença da E-caderina na camada epitelial basal. 14A com figura menor representando o controle negativo. $14 C$ e $14 D$, epitélio da porção dorsal e da porção ventral do rúmen de fetos de 150 dias de desenvolvimento, mostrando a presença da E-caderina na camada epitelial basal. 14E e 14F, epitélio da porção dorsal e da porção ventral do rúmen de bezerros recém-nascidos, mostrando a presença da Ecaderina na camada epitelial basal. $14 G$ e $14 \mathrm{H}$, epitélio da porção dorsal e da porção ventral do rúmen de bovinos adultos, mostrando a presença da E-caderina na camada epitelial basal. E: epitélio; P: papila; CB: camada basal; SM: lâmina própria-submucosa; Q: queratina.

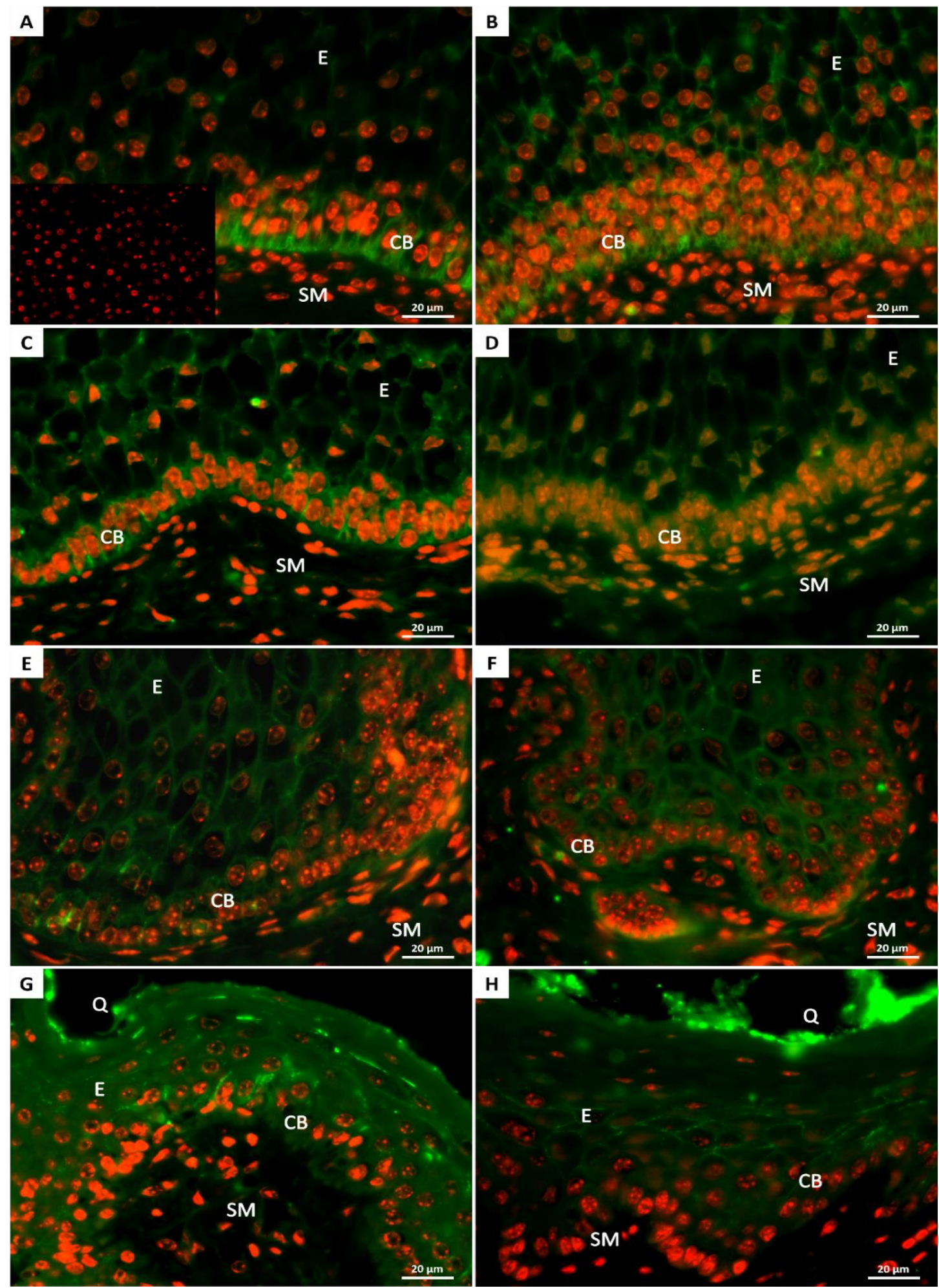

Fonte: Ferrão, J. S. P. (2018). 
Em relação à marcação da E-caderina no epitélio desses animais, foram observadas marcações tênues em membrana celular das células epiteliais nos fetos de 100 dias de desenvolvimento (Figura 18) quando comparadas com as marcações encontradas na camada basal do mesmo, tanto na porção dorsal como na ventral do rúmen. Nos fetos de 150 dias de gestação, a marcação em membrana celular foi mais intensa em relação aos fetos de 110 dias, ocorrendo também a presença de marcação citoplasmática esparsa em algumas regiões das porções dorsal e ventral ruminais. Além disso, na porção ventral ruminal desses animais encontrou-se marcação mais intensa quando comparada à sua porção dorsal. O mesmo padrão de marcação dos fetos de 150 dias pôde ser observado nos bezerros recém-nascidos, uma vez que a marcação da porção ventral ruminal nas membranas celulares foi mais intensa do que na sua porção dorsal do rúmen. No entanto, essas marcações apresentaram-se mais suaves em relação aos fetos de 150 dias de desenvolvimento. Em relação aos bovinos adultos, houve marcação das membranas celulares epiteliais em ambas as porções ruminais de maneira mais acentuada que nos bezerros recém-nascidos em ambas as porções ruminais. Além disso, é possível observar discretas marcações esparsas citoplasmáticas tanto em porção dorsal quanto em porção ventral do rúmen dos adultos (Figura 18). Através dessas observações, pode-se concluir que os fetos de 150 dias de desenvolvimento e os bovinos adultos apresentaram marcações mais intensas que as demais idades estudadas. 
Figura 18: Localização da E-caderina (marcação por FITC) no epitélio ruminal de fetos bovinos, bezerros recém-nascidos e bovinos adultos. $14 \mathrm{~A}$ e $14 \mathrm{~B}$, epitélio da porção dorsal e da porção ventral do rúmen de fetos de 110 dias de desenvolvimento, mostrando a presença da E-caderina nas células do epitélio escamoso estratificado. $14 \mathrm{~A}$ com figura menor representando o controle negativo. $14 \mathrm{C}$ e $14 \mathrm{D}$, epitélio da porção dorsal e da porção ventral do rúmen de fetos de 150 dias de desenvolvimento, mostrando a presença da E-caderina nas células do epitélio escamoso estratificado. $14 E$ e $14 F$, epitélio da porção dorsal e da porção ventral do rúmen de bezerros recém-nascidos, mostrando a presença da E-caderina nas células do epitélio escamoso estratificado. $14 G$ e $14 \mathrm{H}$, epitélio da porção dorsal e da porção ventral do rúmen de bovinos adultos, mostrando a presença da E-caderina nas células do epitélio escamoso estratificado. E: epitélio; P: papila; CB: camada basal; SM: lâmina própria-submucosa; Q: queratina.

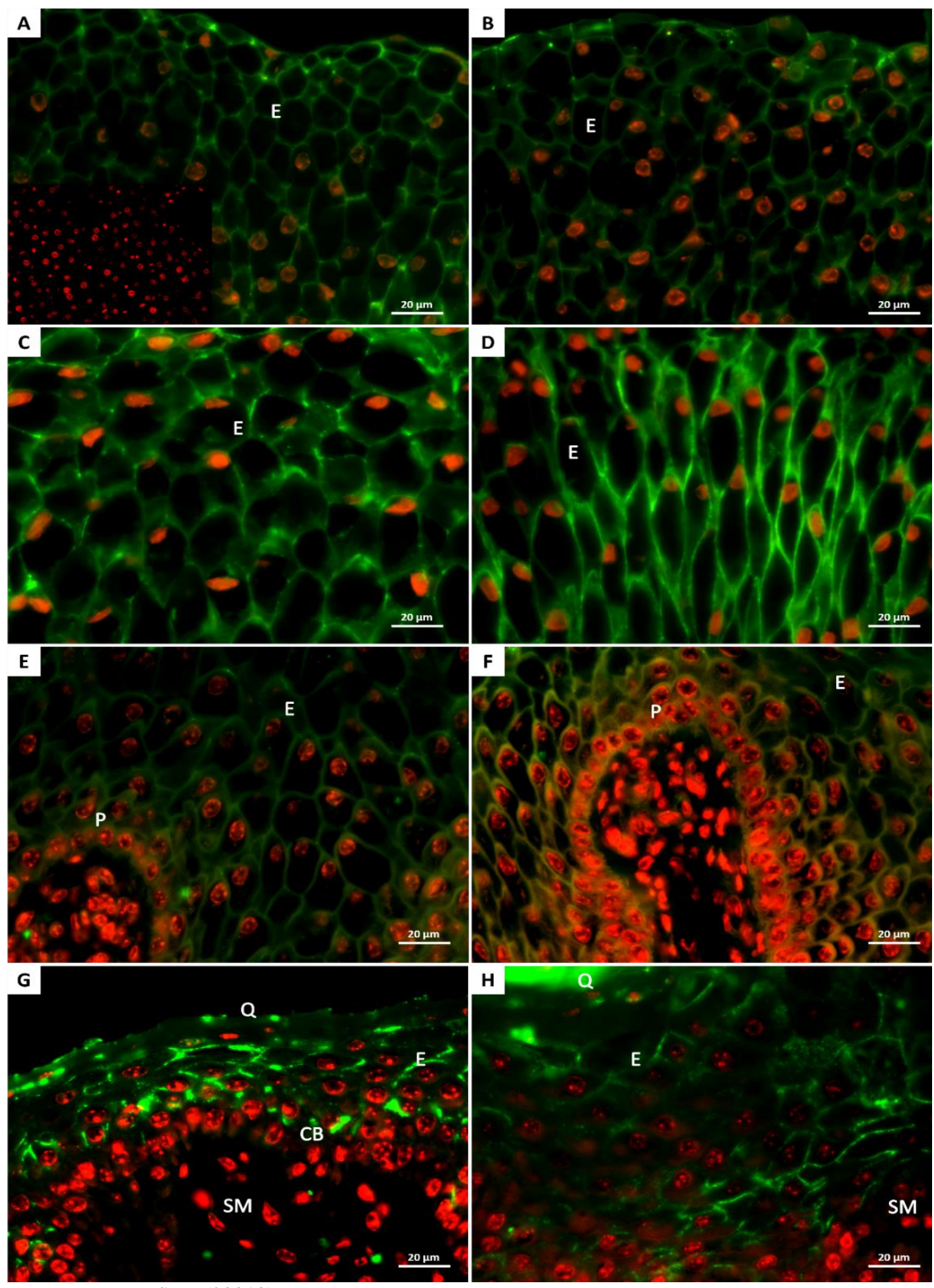

Fonte: Ferrão, J. S. P. (20018). 


\subsection{Análise Biomolecular}

\subsubsection{Extração de RNA}

Após a realização da extração do RNA total das amostras coletadas, foram determinadas as quantidades (concentração) e purezas, utilizando o programa NanoDrop2000 (Quadro 1). As amostras apresentaram o valor de referência 260/280nm entre 1,8 e 2,0, mostrando-se aptas para a montagem das bibliotecas de mRNA e o sequenciamento genético.

\begin{tabular}{|c|c|c|c|c|c|}
\hline & $\begin{array}{c}\text { Número da } \\
\text { Amostra }\end{array}$ & $\begin{array}{l}\text { Nome da } \\
\text { Amostra }\end{array}$ & Concentração & Unidade & $260 / 280$ \\
\hline \multirow{5}{*}{ 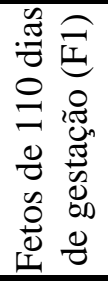 } & $F 1-1$ & F30 Ru.V CA & 2519,2 & $\mathrm{ng} / \mu \mathrm{l}$ & 1,88 \\
\hline & $F 1-2$ & F31 Ru.V CA & 1419,2 & $\mathrm{ng} / \mu \mathrm{l}$ & 1,85 \\
\hline & $\mathrm{F} 1-3$ & F32 Ru.V CR & 1066,5 & $\mathrm{ng} / \mu \mathrm{l}$ & 1,85 \\
\hline & $F 1-4$ & F33 Ru.V CR & 1706,5 & $\mathrm{ng} / \mu \mathrm{l}$ & 1,87 \\
\hline & $\mathrm{F} 1-5$ & F34 Ru.V CR & 1081,7 & $\mathrm{ng} / \mu \mathrm{l}$ & 1,85 \\
\hline \multirow{5}{*}{ 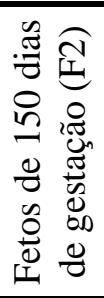 } & $\mathrm{F} 2-6$ & F44 Ru.V CR & 915,4 & $\mathrm{ng} / \mu \mathrm{l}$ & 1,81 \\
\hline & $\mathrm{F} 2-7$ & F44 Ru.V CA & 1111,6 & $\mathrm{ng} / \mu \mathrm{l}$ & 1,81 \\
\hline & $\mathrm{F} 2-8$ & F45 Ru.V CR & 1123,3 & $\mathrm{ng} / \mu \mathrm{l}$ & 1,77 \\
\hline & $\mathrm{F} 2-9$ & F46 Ru.V CA & 1362,1 & $\mathrm{ng} / \mu \mathrm{l}$ & 1,80 \\
\hline & $\mathrm{F} 2-10$ & F47 Ru.V CR & 1229,1 & $\mathrm{ng} / \mu \mathrm{l}$ & 1,80 \\
\hline \multirow{5}{*}{ 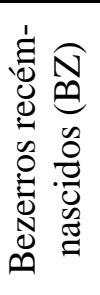 } & $\mathrm{BZ}-11$ & B32 Ru.V & 1162,9 & $\mathrm{ng} / \mu \mathrm{l}$ & 1,98 \\
\hline & $\mathrm{BZ}-12$ & B34 Ru.V & 1122,0 & $\mathrm{ng} / \mu \mathrm{l}$ & 1,98 \\
\hline & $\mathrm{BZ}-13$ & B35 Ru.V & 1417,9 & $\mathrm{ng} / \mu \mathrm{l}$ & 1,95 \\
\hline & $\mathrm{BZ}-14$ & B36 Ru.V & 1778,1 & $\mathrm{ng} / \mu \mathrm{l}$ & 1,86 \\
\hline & $\mathrm{BZ}-15$ & B37 Ru.V & 2252,1 & $\mathrm{ng} / \mu \mathrm{l}$ & 1,91 \\
\hline \multirow{5}{*}{$\begin{array}{l}\widehat{2} \\
\frac{1}{0} \\
0 \\
\frac{0}{3} \\
\frac{2}{4}\end{array}$} & $A D-16$ & A30 Ru.V & 1717,6 & $\mathrm{ng} / \mu \mathrm{l}$ & 1,98 \\
\hline & $\mathrm{AD}-17$ & A31 Ru.V & 1979,6 & $\mathrm{ng} / \mu \mathrm{l}$ & 1,97 \\
\hline & $\mathrm{AD}-18$ & A7 Ru.V & 1499,0 & $\mathrm{ng} / \mu \mathrm{l}$ & 1,99 \\
\hline & $\mathrm{AD}-19$ & A10 Ru.V & 1684,3 & $\mathrm{ng} / \mu \mathrm{l}$ & 1,93 \\
\hline & $A D-20$ & A11 Ru.V & 1378,9 & $\mathrm{ng} / \mu \mathrm{l}$ & 2,00 \\
\hline
\end{tabular}

Em seguida, foram realizados os géis de agarose $1 \%$ para verificação da integridade e pureza das amostras. Nos géis é possível observar as bandas formadas pelo RNA (28S e 18S), nas amostras de fetos, bezerros e adultos (Figuras 19 a 22). 
Figura 19: Gel de Agarose 1\% dos fetos de 110 dias de gestação. É possível observar as bandas 28S e 18S do RNA.

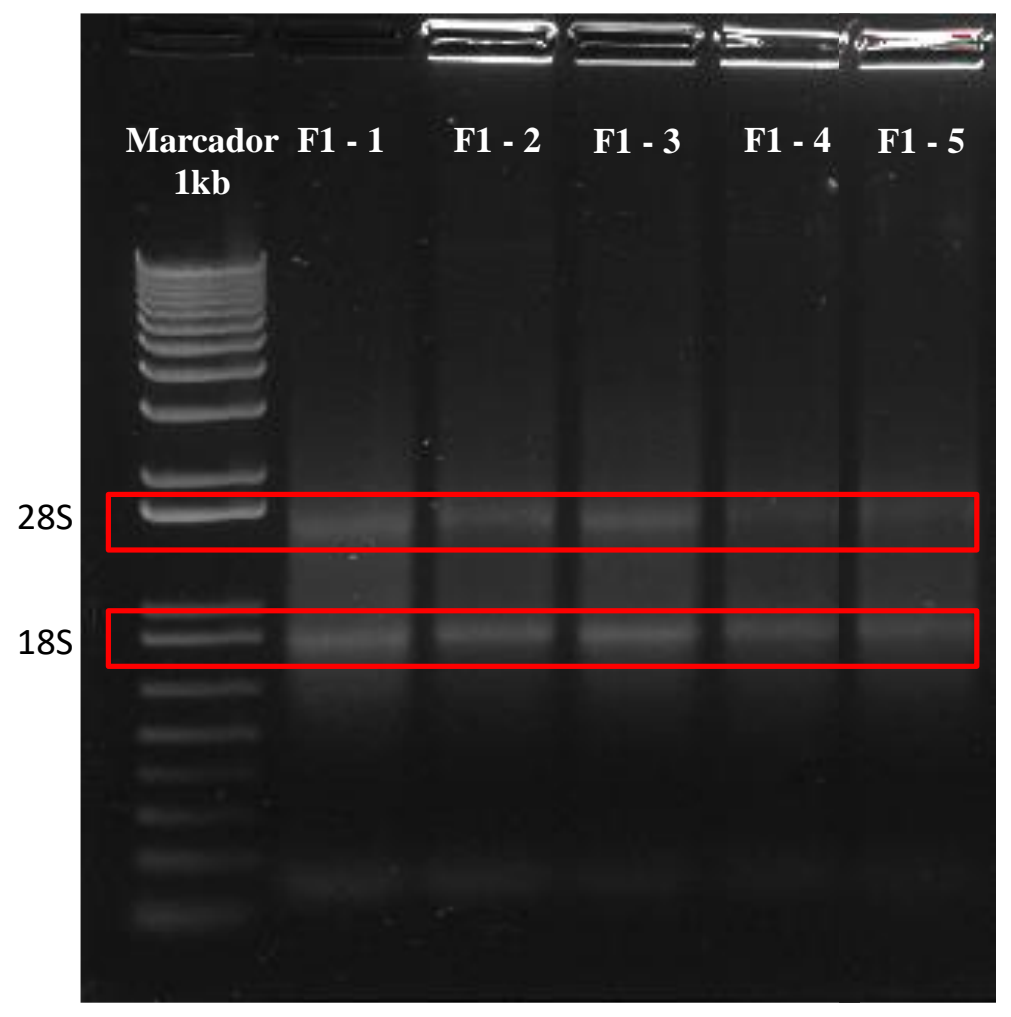

Fonte: Ferrão, J. S. P. (2018).

Figura 20: Gel de Agarose 1\% dos fetos de 150 dias de gestação. É possível observar as bandas 28S e 18S do RNA.

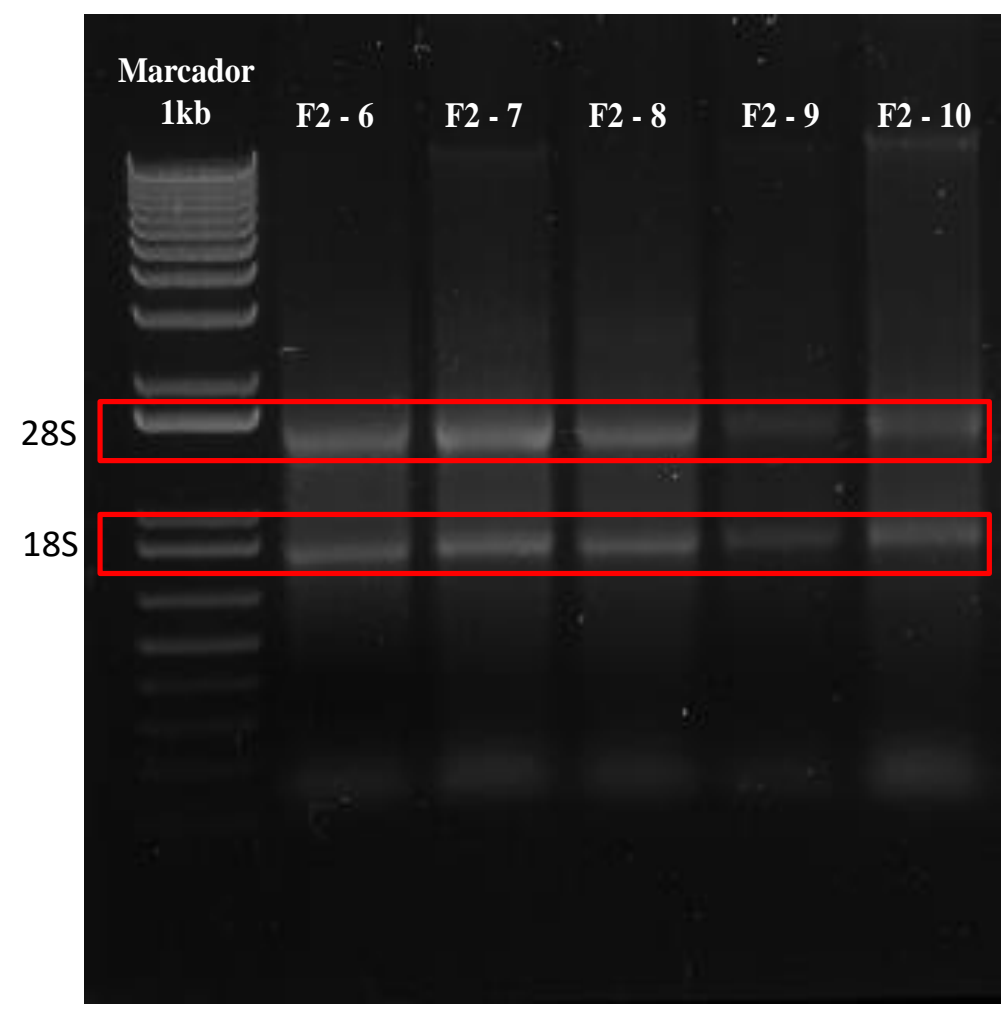

Fonte: Ferrão, J. S. P. (2018). 
Figura 21: Gel de Agarose 1\% dos bezerros recém-nascidos. É possível observar as bandas 28S e 18S do RNA.

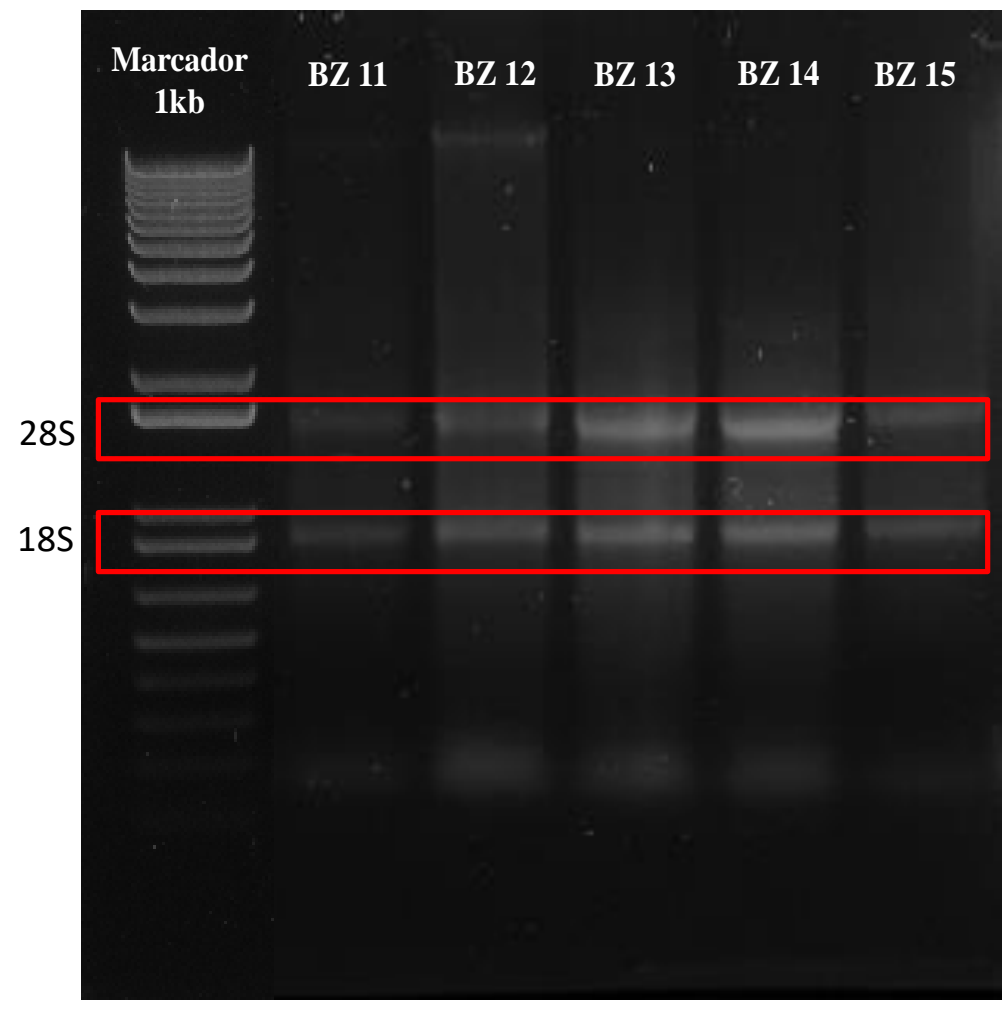

Fonte: Ferrão, J. S. P. (2018).

Figura 22: Gel de Agarose 1\% dos bovinos adultos. É possível observar as bandas 28S e 18S do RNA.

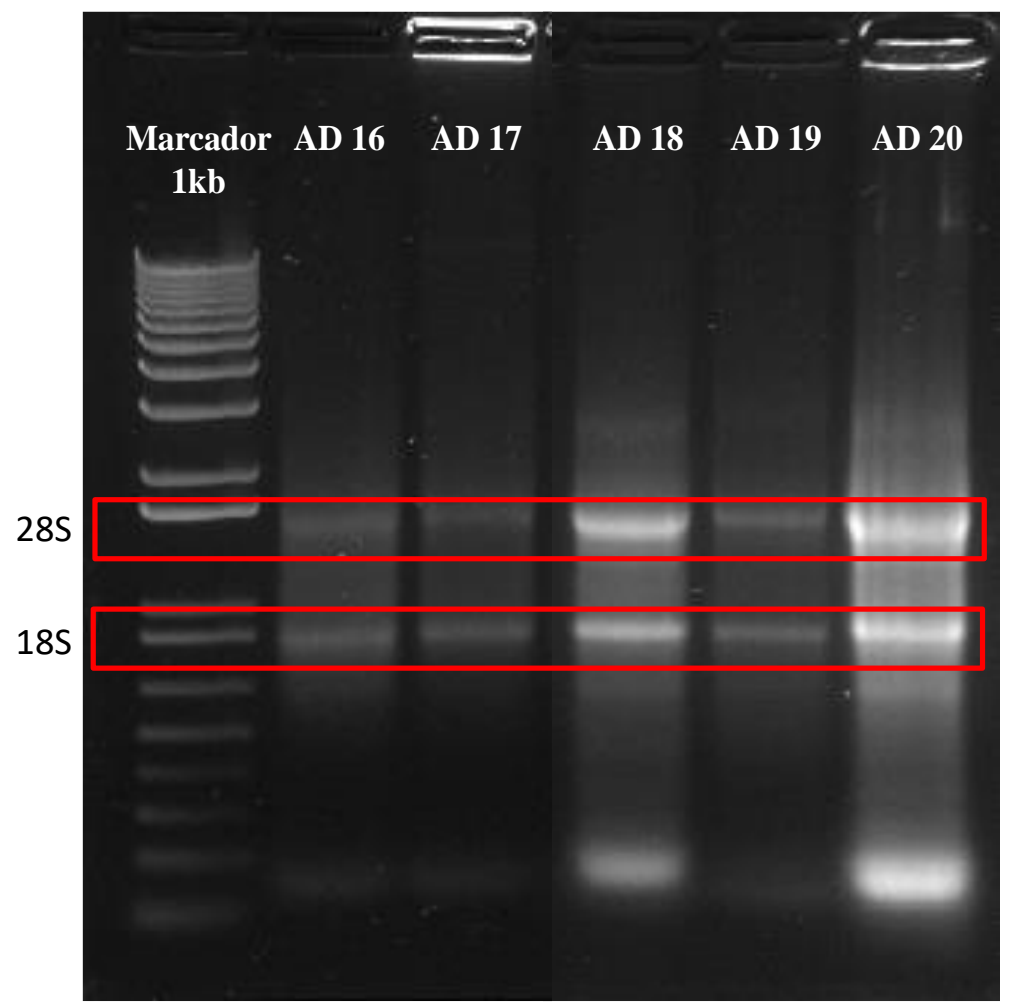

Fonte: Ferrão, J. S. P. (2018). 
6.6.2 Preparo das bibliotecas de mRNA e sequenciamento genético

As amostras foram, então, encaminhadas para o Laboratório de Biotecnologia Animal, na Escola Superior de Agricultura "Luiz de Queiroz" (ESALQ/USP). A qualidade e a integridade do RNA total foram analisadas através do Agilent 2100 Bioanalyser (Agilent Technologies). Apenas amostras com RNA total apresentando RNA Integrity Number (RIN) próximo a 8,0 serão utilizadas para as análises de RNAseq (Quadro 2 e Figuras 23 e 24).

Quadro 2: Análise do RIN (RNA Integrity Number) das amostras realizada no Laboratório de Biotecnologia Animal (ESALQ/USP)

\begin{tabular}{|c|c|c|c|}
\hline & $\begin{array}{c}\text { Número da } \\
\text { Amostra }\end{array}$ & Nome da Amostra & RIN \\
\hline \multirow{5}{*}{ 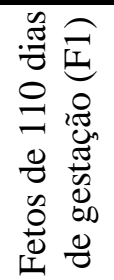 } & $F 1-1$ & F30 Ru.V CA & 7,20 \\
\hline & $\mathrm{F} 1-2$ & F31 Ru.V CA & 7,20 \\
\hline & $F 1-3$ & F32 Ru.V CR & 7,00 \\
\hline & $\mathrm{F} 1-4$ & F33 Ru.V CR & 8,60 \\
\hline & $F 1-5$ & F34 Ru.V CR & 7,20 \\
\hline \multirow{5}{*}{ 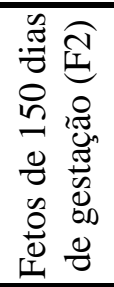 } & $\mathrm{F} 2-6$ & F44 Ru.V CR & 7,40 \\
\hline & $\mathrm{F} 2-7$ & F44 Ru.V CA & 8,40 \\
\hline & $\mathrm{F} 2-8$ & F45 Ru.V CR & 8,00 \\
\hline & $\mathrm{F} 2-9$ & F46 Ru.V CA & 7,70 \\
\hline & $\mathrm{F} 2-10$ & F47 Ru.V CR & 9,60 \\
\hline \multirow{5}{*}{ 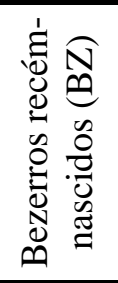 } & $\mathrm{BZ}-11$ & B32 Ru.V & 7,70 \\
\hline & $\mathrm{BZ}-12$ & B34 Ru.V & 7,70 \\
\hline & $\mathrm{BZ}-13$ & B35 Ru.V & 8,10 \\
\hline & $\mathrm{BZ}-14$ & B36 Ru.V & 7,20 \\
\hline & $\mathrm{BZ}-15$ & B37 Ru.V & 7,40 \\
\hline \multirow{5}{*}{$\begin{array}{l}\widehat{Q} \\
\frac{1}{0} \\
\frac{0}{3} \\
\frac{3}{2}\end{array}$} & $\mathrm{AD}-16$ & A30 Ru.V & 9,30 \\
\hline & $\mathrm{AD}-17$ & A31 Ru.V & 9,40 \\
\hline & $\mathrm{AD}-18$ & A7 Ru.V & 8,30 \\
\hline & $\mathrm{AD}-19$ & A10 Ru.V & 7,80 \\
\hline & $A D-20$ & A11 Ru.V & 7,80 \\
\hline
\end{tabular}


Figura 23: Gráficos do RNA total das amostras de fetos de 110 (A a E) e 150 (F a J) dias de gestação analisadas através do Agilent 2100 Bioanalyser. (A) Amostra F1 - 1 (F30 Ru.V CA), (B) Amostra F1 - 2 (F31 Ru.V CA), (C) Amostra F1 - 3 (F32 Ru.V CR), (D) Amostra F1 - 4 (F33 Ru.V CR), (E) Amostra F1 - 5 (F34 Ru.V CR), (F) Amostra F2 - 6 (F44 Ru.V CR), (G) Amostra F2 - 7 (F44 Ru.V CA), (H) Amostra F2 - 8 (F45 Ru.V CR), (I) Amostra F2 - 9 (F46 Ru.V CA), (J) Amostra F2 - 10 (F47 Ru.V CR).
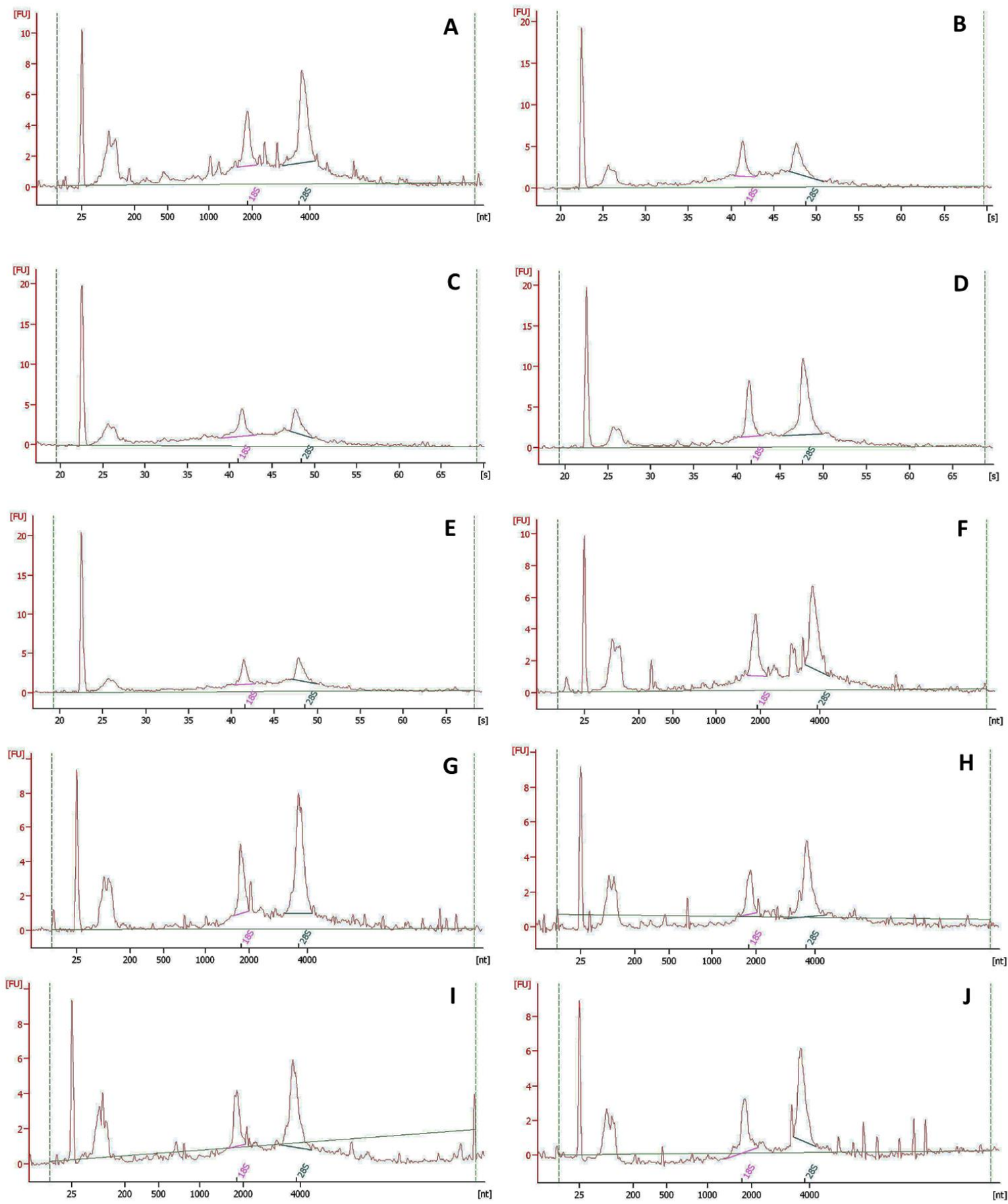

Fonte: Ferrão, J. S. P. (20018). 
Figura 24: Gráficos do RNA total das amostras de bezerros recém-nascidos (A a $\mathbf{E})$ e bovinos adultos (F a J) de gestação analisadas através do Agilent 2100 Bioanalyser. (A) Amostra BZ - 11 (B32 Ru.V), (B) Amostra BZ - 12 (B34 Ru.V), (C) Amostra BZ - 13 (B35 Ru.V), (D) Amostra BZ - 14 (B36 Ru.V), (E) Amostra BZ - 15 (B37 Ru.V), (F) Amostra AD - 16 (A30 Ru.V), (G) Amostra AD - 17 (A31 Ru.V), (H) Amostra AD - 18 (A7 Ru.V), (I) Amostra AD - 19 (A10 Ru.V), (J) Amostra AD - 20 (F11 Ru.V).
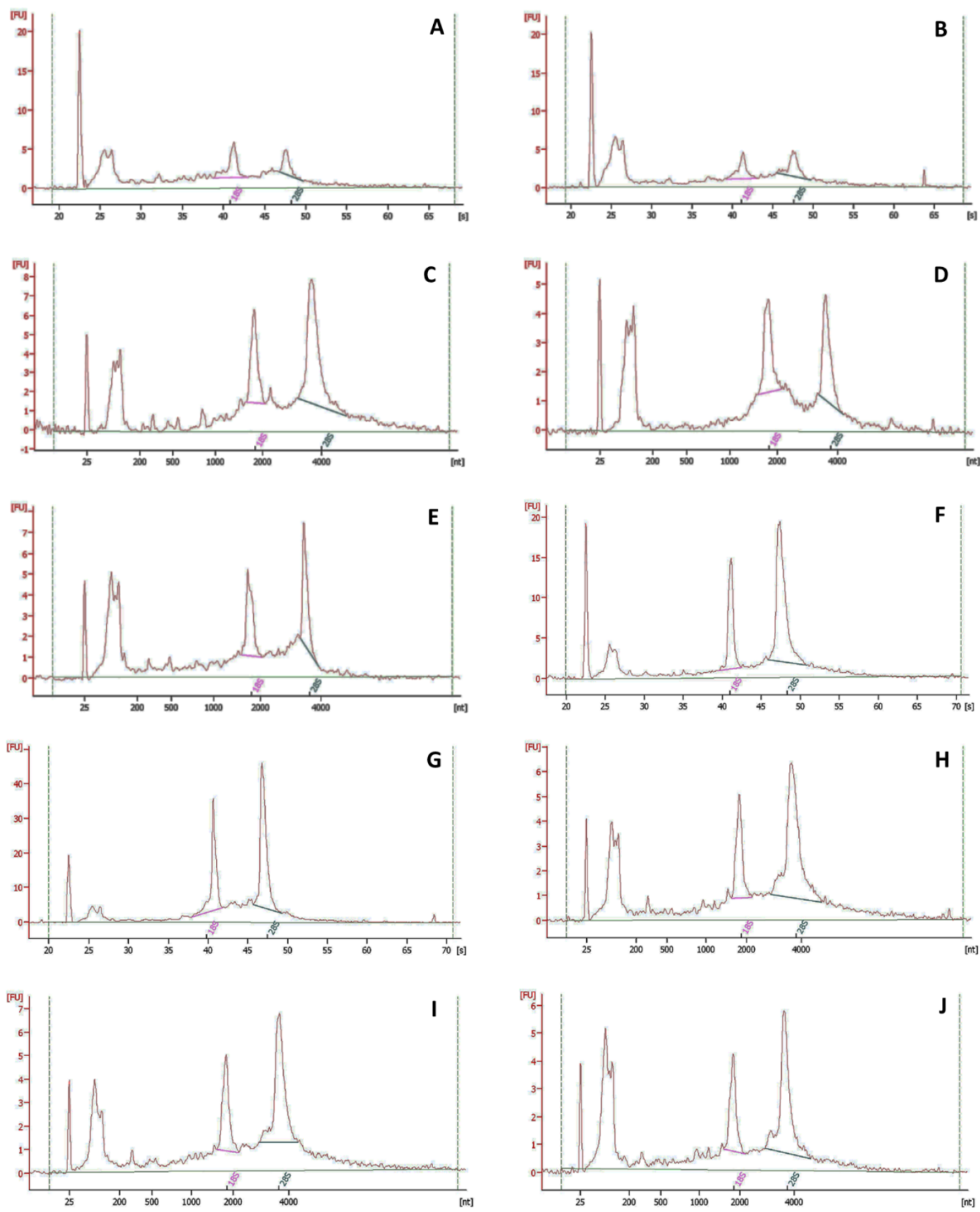

Fonte: Ferrão, J. S. P. (20018). 


\subsection{Análise de Bioinformática}

Após a análise de bioinformática, os seguintes resultados foram obtidos.

\subsubsection{Mapeamento no genoma de Bos taurus}

No mapeamento do genoma das amostras de todas as idades estudadas obteve-se mais de $90 \%$ dos reads mapeados unicamente, menos de $4,3 \%$ dos reads mapeados em múltiplos loci e menos de 4,4\% dos reads não mapeados (Tabela 8).

Tabela 8 - Taxa (em \%) de mapeamento por amostra do genoma de Bos taurus, mostrando reads mapeados e não mapeados.

\begin{tabular}{|c|c|c|c|}
\hline Amostra & $\begin{array}{l}\text { Reads mapeados } \\
\text { unicamente (\%) }\end{array}$ & $\begin{array}{l}\text { Reads mapeados em } \\
\text { loci múltiplos (\%) }\end{array}$ & $\begin{array}{c}\text { Reads não } \\
\text { mapeados (\%) }\end{array}$ \\
\hline$F 1-1$ & 93.91 & 3.14 & 2.95 \\
\hline $\mathrm{F} 1-2$ & 93.76 & 3.41 & 2.83 \\
\hline$F 1-3$ & 94.00 & 3.43 & 2.57 \\
\hline $\mathrm{F} 1-4$ & 92.73 & 3.75 & 3.52 \\
\hline$F 1-5$ & 92.90 & 3.84 & 3.26 \\
\hline$F 2-6$ & 92.85 & 3.13 & 4.02 \\
\hline $\mathrm{F} 2-7$ & 93.71 & 3.25 & 3.04 \\
\hline $\mathrm{F} 2-8$ & 93.12 & 3.72 & 3.16 \\
\hline $\mathrm{F} 2-9$ & 92.73 & 3.52 & 3.75 \\
\hline$F 2-10$ & 92.25 & 3.39 & 4.36 \\
\hline $\mathrm{BZ}-11$ & 94.13 & 3.59 & 2.28 \\
\hline $\mathrm{BZ}-12$ & 93.31 & 4.22 & 2.47 \\
\hline $\mathrm{BZ}-13$ & 93.97 & 2.74 & 3.29 \\
\hline $\mathrm{BZ}-14$ & 93.42 & 3.26 & 3.32 \\
\hline $\mathrm{BZ}-15$ & 93.97 & 3.96 & 2.07 \\
\hline
\end{tabular}




\begin{tabular}{lccc}
\hline $\mathrm{AD}-16$ & 92.61 & 4.14 & 3.25 \\
\hline $\mathrm{AD}-17$ & 92.16 & 4.69 & 3.15 \\
\hline $\mathrm{AD}-18$ & 91.88 & 4.87 & 3.25 \\
\hline $\mathrm{AD}-19$ & 91.87 & 4.88 & 3.25 \\
\hline $\mathrm{AD}-20$ & 92.35 & 4.96 & 2.68 \\
\hline
\end{tabular}

\subsubsection{Análise de expressão diferencial}

Após a análise de expressão gênica diferencial, obteve-se a Tabela 9, onde a comparação é realizada por contraste entre as diferentes idades, sendo feita em pares de idades, e os genes "up" são comparados com os genes "down" dos diferentes grupos de idades estudadas.

Tabela 9 - Número de genes diferencialmente expressos por contraste. Genes "up" são mais expressos no primeiro elemento do contraste, genes “down” são mais expressos no segundo elemento. Outliers são genes com variância muito grande.

\begin{tabular}{lccccc}
\hline Contraste & Genes & Up & Down & Outliers & Low counts \\
\hline F1 vs F2 & 12203 & 0 & 0 & 16 & 0 \\
\hline F1 vs BZ & 12203 & 529 & 148 & 16 & 0 \\
\hline F1 vs AD & 12203 & 1152 & 456 & 16 & 0 \\
\hline F2 vs BZ & 12203 & 261 & 106 & 16 & 0 \\
\hline F2 vs AD & 12203 & 965 & 423 & 16 & 0 \\
\hline BZ vs AD & 12203 & 251 & 170 & 16 & 0 \\
\hline
\end{tabular}




\section{$\underline{\text { 6.7.3 Enriquecimento de categorias KEGG e GO }}$}

Após a análise de enriquecimento da categoria KEGG, obteve-se a Tabela, onde é realizada a comparação para diferentes vias metabólicas entre as diferentes idades estudadas, sendo feita em pares de idades, e os genes "up" são comparados com os genes "down" dos diferentes grupos de idades estudadas (Tabela 10).

Tabela 10 - Número de vias metabólicas KEGG diferencialmente reguladas entre os contrastes. Vias "up" são mais expressas no primeiro elemento do contraste, vias "down" são mais expressas no segundo elemento.

\begin{tabular}{cccc}
\hline Contraste & Vias & up & down \\
\hline F1 vs F2 & 238 & 0 & 0 \\
\hline F1 vs BZ & 238 & 18 & 12 \\
\hline F1 vs AD & 238 & 16 & 41 \\
\hline F2 vs BZ & 238 & 21 & 14 \\
\hline F2 vs AD & 238 & 15 & 43 \\
\hline BZ vs AD & 238 & 0 & 27 \\
\hline
\end{tabular}

Após a análise de enriquecimento da categoria GO, obtiveram-se as Tabelas, onde é realizada a comparação para diferentes categorias GO entre as diferentes idades estudadas, sendo feita em pares de idades, e os genes "up" são comparados com os genes "down" dos diferentes grupos de idades estudadas.

A Tabela 11 representa o número de caterigoras $\mathrm{GO}$ relacionadas a processos biológicos reguladas diferencialmente pelos genes identificados. A Tabela 12 representa o número de caterigoras $\mathrm{GO}$ relacionadas a funções moleculares reguladas diferencialmente pelos genes identificados. A Tabela 13 representa o número de caterigoras GO relacionadas a compartimentos celulares reguladas diferencialmente pelos genes identificados. 
Tabela 11 - Número de categorias "GO biological process" diferencialmente reguladas entre os contrastes. Categorias "up" são mais expressas no primeiro elemento do contraste, Categorias "down" são mais expressas no segundo elemento.

\begin{tabular}{cccc}
\hline Contraste & Categorias & up & down \\
\hline F1 vs F2 & 10670 & 0 & 0 \\
\hline F1 vs BZ & 10670 & 46 & 68 \\
\hline F1 vs AD & 10670 & 6 & 104 \\
\hline F2 vs BZ & 10670 & 81 & 109 \\
\hline F2 vs AD & 10670 & 9 & 111 \\
\hline BZ vs AD & 10670 & 0 & 36 \\
\hline
\end{tabular}

Tabela 12 - Número de categorias "GO molecular function" diferencialmente reguladas entre os contrastes. Categorias "up" são mais expressas no primeiro elemento do contraste, Categorias "down" são mais expressas no segundo elemento.

\begin{tabular}{cccc}
\hline Contraste & Categorias & up & down \\
\hline F1 vs F2 & 3029 & 0 & 0 \\
\hline F1 vs BZ & 3029 & 27 & 14 \\
\hline F1 vs AD & 3029 & 4 & 17 \\
\hline F2 vs BZ & 3029 & 25 & 13 \\
\hline F2 vs AD & 3029 & 6 & 18 \\
\hline BZ vs AD & 3029 & 0 & 0 \\
\hline
\end{tabular}


Tabela 13 - Número de categorias "GO cellular compartment" diferencialmente reguladas entre os contrastes. Categorias "up" são mais expressas no primeiro elemento do contraste, Categorias "down” são mais expressas no segundo elemento.

\begin{tabular}{cccc}
\hline Contraste & Categorias & up & down \\
\hline F1 vs F2 & 1350 & 0 & 0 \\
\hline F1 vs BZ & 1350 & 39 & 55 \\
\hline F1 vs AD & 1350 & 34 & 45 \\
\hline F2 vs BZ & 1350 & 37 & 68 \\
\hline F2 vs AD & 1350 & 39 & 46 \\
\hline BZ vs AD & 1350 & 0 & 10 \\
\hline
\end{tabular}

6.7.4 Comparação entre as diferentes proteínas estudadas - Cx26, Cx32, Cx40, Cx43 e E-caderina

Quando realizada a comparação do mapeamento nas diferentes idades estudadas, para os genes de interesse (Conexinas 26, 32, 40 e 43; E-caderina), pode-se observar diferentes padrões de expressão para cada proteína estudada em relação à cada idade estudada.

Na figura 25 é possível observar a expressão média de cada amostra, de cada idade. É possível verificar que a expressão gênica dos fetos é semelhante, uma vez que a expressão de suas amostras se encontra próxima uma das outras, de maneira agrupada. Além disso, pode-se observar que a expressão entre as diferentes idades estudadas, grupo de fetos, bezerros recém-nascidos e bovinos adultos possuem diferentes expressões gênicas, uma vez que cada animal se encontra em uma fase diferente de desenvolvimento e dessa maneira seu epitélio ruminal também apresenta diferentes estágio de desenvolvimento, sendo esperada, então, essa diferença na expressão gênica do tecido epitelial de cada idade. 
Figura 25 - Gráfico mostrando a distância entre as diferenças de expressão média entre amostras, calculadas com base nos 500 genes com maior diferença de expressão. F1 - Fetos de 110 dias de desenvolvimento. F2 - Fetos de 150 dias de desenvolvimento. BZ - Bezerros recém-nascidos. AD Bovinos adultos.

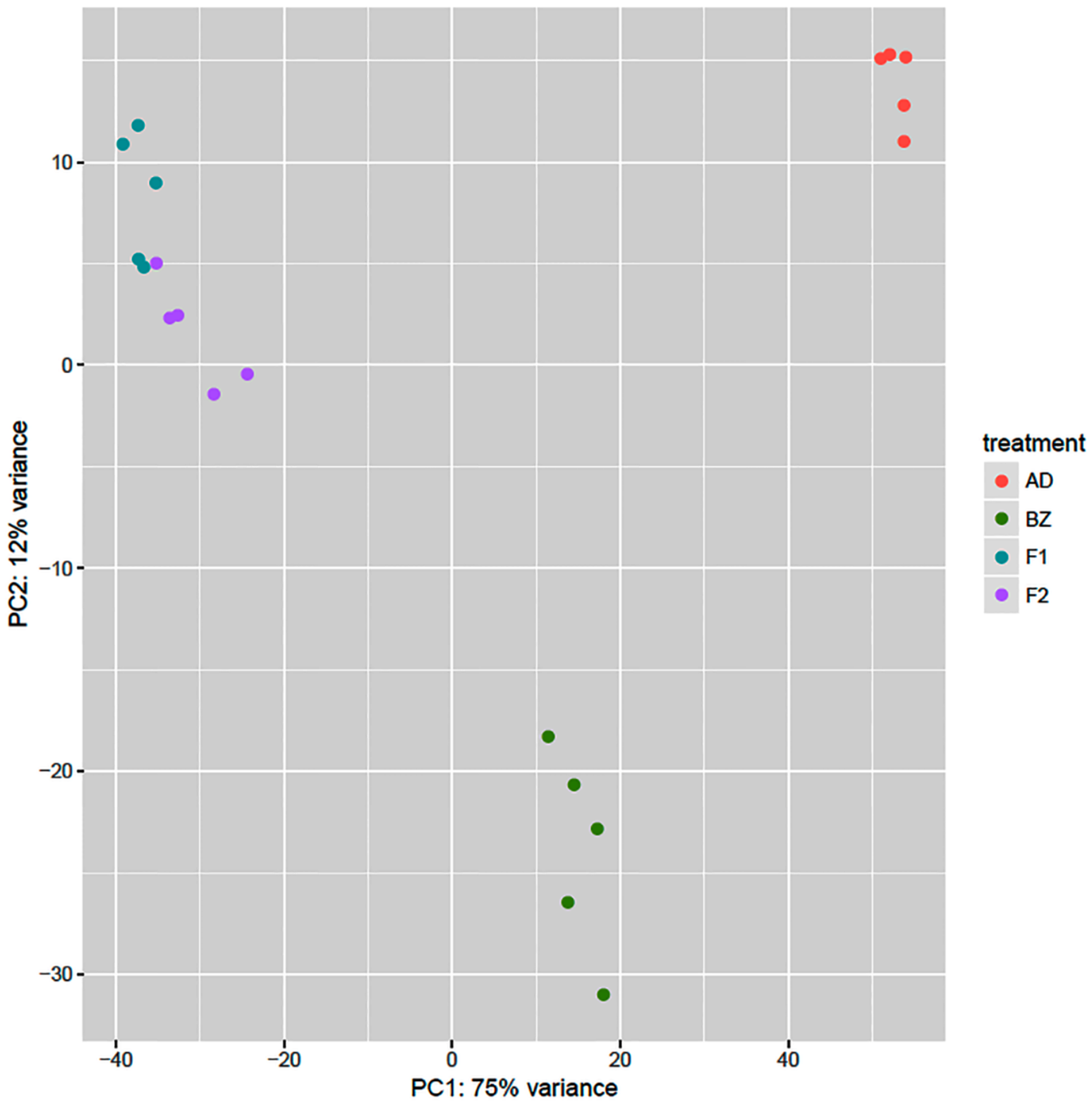


Na figura 26 é possível observar a diferença entre a expressão da Cx26 (GJB2) nas diferentes idades estudadas. Os fetos apresentaram expressões menores quando comparados aos bezerros e adultos, enquanto que os adultos apresentaram a maior expressão gênica para a Cx26 quando comparado às outras idades.

Figura 26 - Gráfico da Conexina 26 (GJB2). O gráfico representa número de leituras de sequenciamento mapeadas no gene (eixo Y) por tratamento - idade estudadas (eixo X).

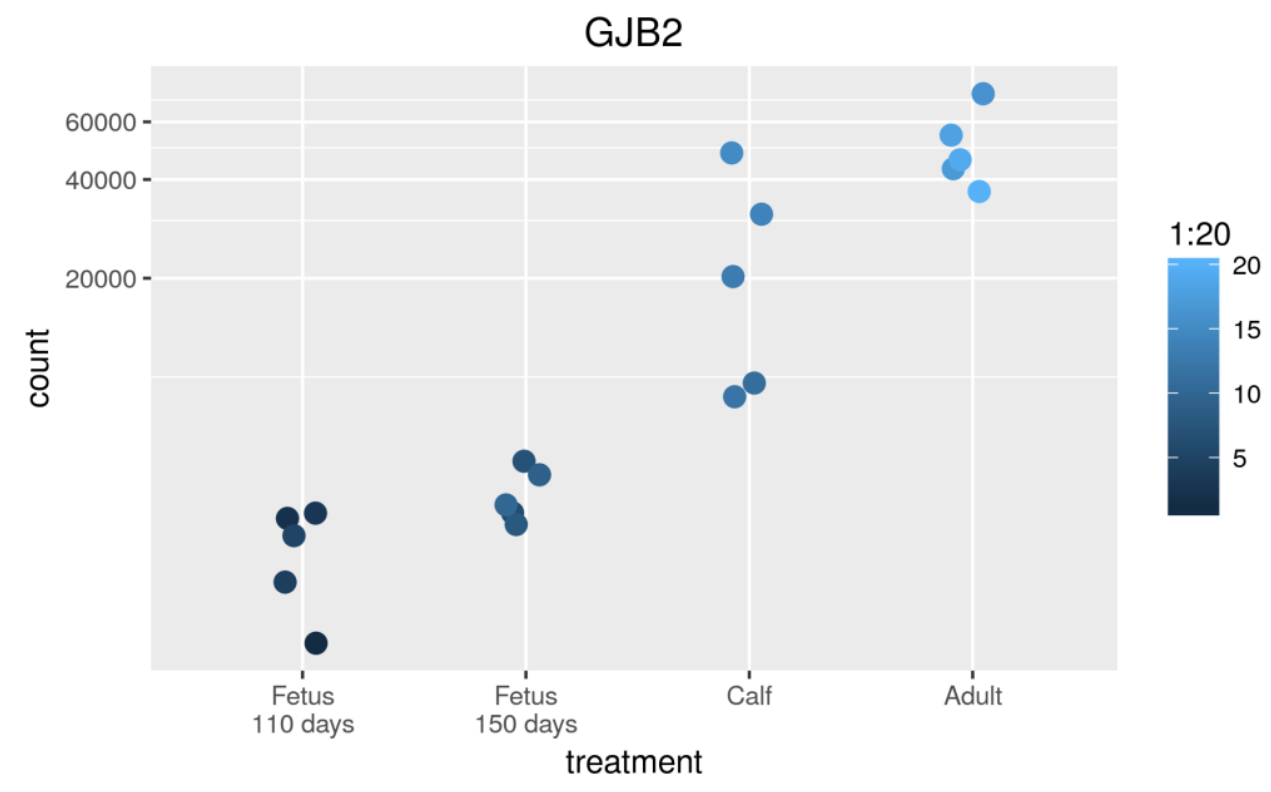

A expressão da Cx32 não foi detectada em nenhuma das idades estudadas, ou quando detectada, era extremamente insignificante.

Na figura 27 é possível observar a diferença entre a expressão da Cx40 (GJA5) nas diferentes idades estudadas. Os fetos apresentaram expressões similares e maiores quando comparados aos bezerros e adultos, enquanto que os bezerros e adultos apresentaram expressão gênica para a $\mathrm{Cx} 40$ de modo similar e menores. 
Figura 27 - Gráfico da Conexina 40 (GJA5). O gráfico representa número de leituras de sequenciamento mapeadas no gene (eixo Y) por tratamento - idade estudadas (eixo X).

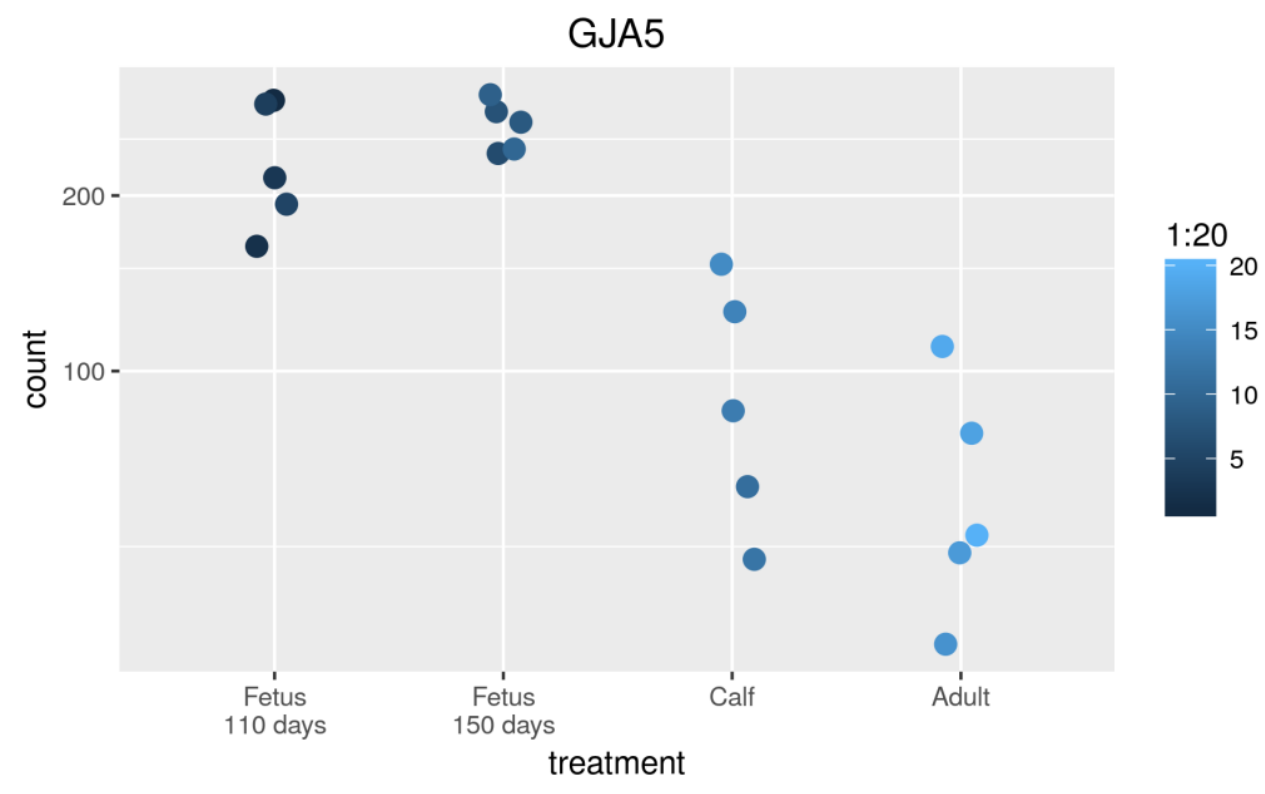

Na figura 28 é possível observar a diferença entre a expressão da Cx43 (GJA1) nas diferentes idades estudadas. A expressão para a $\mathrm{Cx} 43$ foi semelhante que a encontrada para a $\mathrm{Cx} 26$, onde os fetos apresentaram expressões menores quando comparados aos bezerros e adultos, enquanto que os adultos apresentaram a maior expressão gênica para a $\mathrm{Cx} 43$ quando comparado às outras idades.

Figura 28 - Gráfico da Conexina 43 (GJA1). O gráfico representa número de leituras de sequenciamento mapeadas no gene (eixo Y) por tratamento - idade estudadas (eixo X).

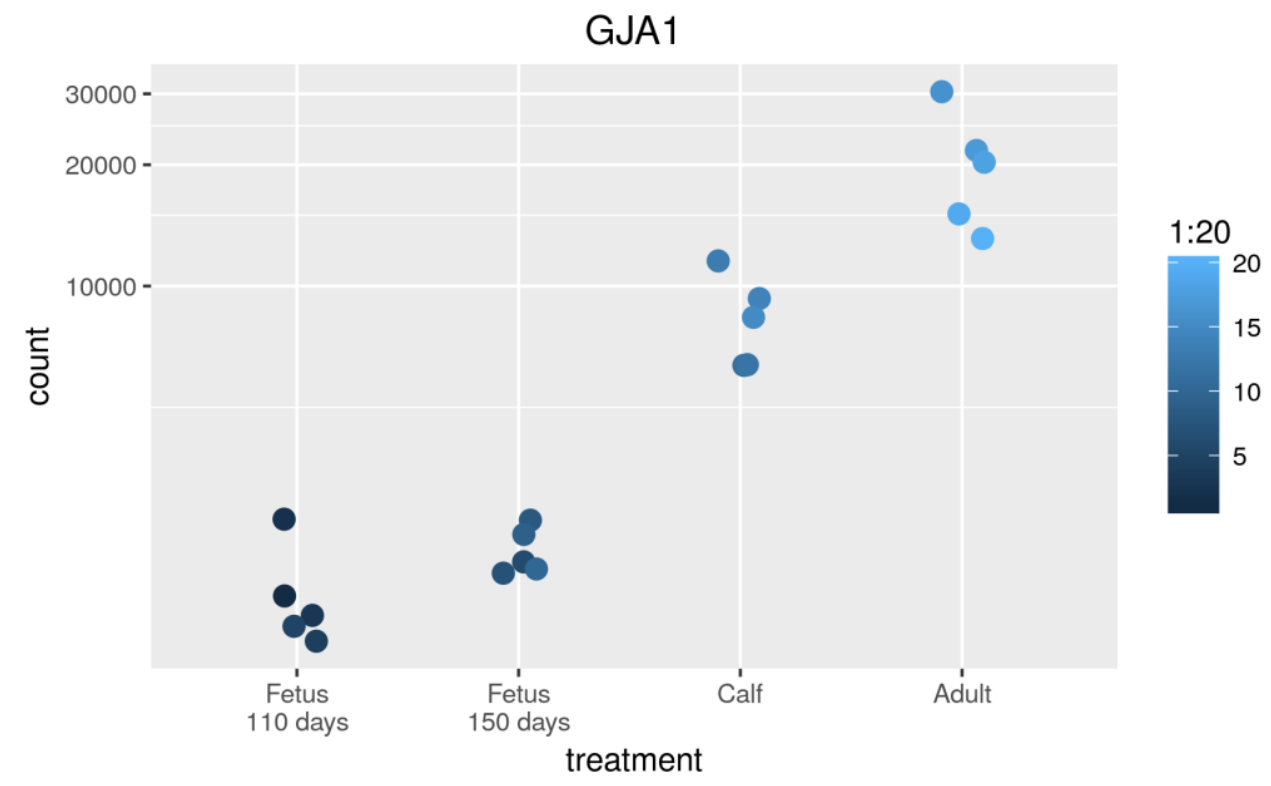


Na figura 29 é possível observar a diferença entre a expressão da E-caderina (CDH1) nas diferentes idades estudadas. A expressão para a E-caderina foi semelhante em todas as idades estudadas, divergindo apenas entre algumas amostras de cada idade.

Figura 29 - Gráfico da E-caderina (CDH1). O gráfico representa número de leituras de sequenciamento mapeadas no gene (eixo Y) por tratamento - idade estudadas (eixo X).

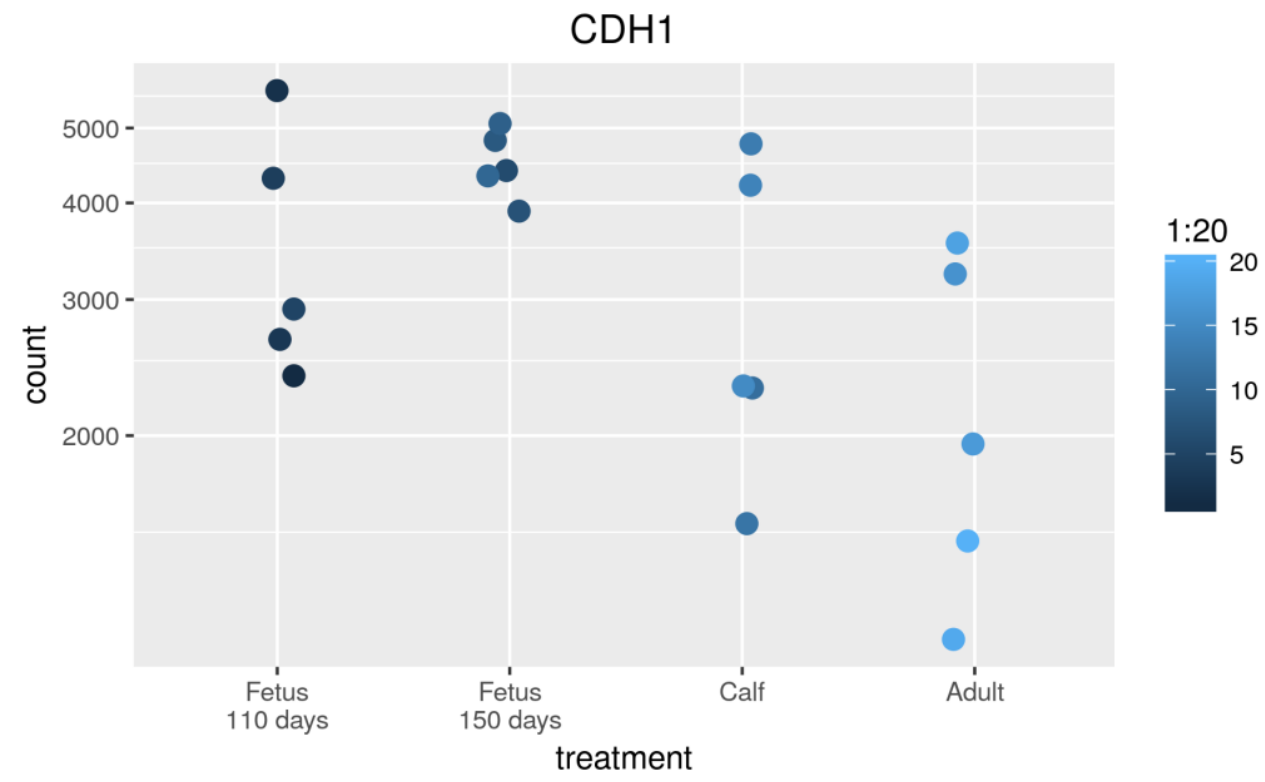


7 Discussão 


\section{DISCUSSÃO}

Durante o desenvolvimento fetal e pós-natal do rúmen de bovinos, o mesmo passa por modificações anatômicas e fisiológicas para se adaptar ao crescimento do animal e ao seu tipo de alimentação (líquido para sólido). No presente trabalho essas modificações foram observadas através da microscopia óptica e eletrônica, sendo possível realizar comparações entre as diferentes idades estudadas. Além disso, foram realizadas bibliotecas de mRNA e o seu sequenciamento genético.

Em relação à morfologia, nos fetos de 110 e 150 dias de desenvolvimento, o epitélio ruminal não apresenta estratificação, possuindo somente um tipo celular epitelial, enquanto que os bezerros recém-nascidos já apresentam o epitélio pavimentoso estratificado, mas ainda sem a queratinização observada no epitélio de bovinos adultos. Quando comparadas as porções dorsal e ventral entre si, não ocorreram diferenças nas idades estudadas, podendo indicar que o desenvolvimento do epitélio ruminal acontece de maneira homogênea em todo o órgão.

No entanto, quando comparadas as mensurações entre as diferentes idades, podese notar que os fetos de 150 dias de desenvolvimento apresentaram o epitélio mais espesso que as outras idades, podendo este fato ser uma evidência da preparação do epitélio ruminal para o desenvolvimento papilar. Nessa idade (150 dias de desenvolvimento), as papilas começam a invadir a camada intermediária do tecido epitelial, através de projeções da lâmina própria submucosa, a qual empurra a camada basal para a superfície. Desse modo, o epitélio gradualmente desaparece em bezerros recém-nascidos. Ao nascimento, as papilas ruminais se projetam da superfície epitelial, provavelmente devido à regressão das células epiteliais que cercam essas papilas. Resultados semelhantes foram encontrados por García et al., (2012), que realizaram análises morfométricas do rúmen de fetos de cabras durante todo o período gestacional e ao compararem suas mensurações demonstraram que o período mais avançado de gestação possui o epitélio mais espesso.

Porém, o epitélio ruminal dos bezerros recém-nascidos possui espessura semelhante à dos fetos de 110 dias de desenvolvimento, uma vez que nos bezerros já são encontradas as papilas, mesmo que ainda não completamente desenvolvidas (STEELE et al., 2015, 2016). Nos bezerros recém-nascidos, o epitélio encontrado é pavimentoso estratificado, como no adulto. No entanto, ele ainda não sofreu queratinização, uma vez que ele ainda não está se alimentando de sólidos e, dessa maneira, não há estímulo para a formação de queratina para a proteção epitelial. Esse tecido epitelial, que é bem reduzido, ao nascimento pode possuir uma função de suporte estrutural para o desenvolvimento papilar. Quando ele regride, as papilas emergem através das camadas de tecido epitelial circunjacente. Além disso, conforme ocorre o desmame do bezerro, as partículas de alimentos sólidos ingeridos causam o desgaste gradual desse epitélio, ajudando no desenvolvimento papilar e diminuindo a espessura desse tecido, deixando as papilas mais expostas ao ambiente ruminal. 
Bovinos adultos apresentam suas papilas ruminais bem desenvolvidas, enquanto que nos bezerros elas ainda se encontram em fase de desenvolvimento. As papilas apenas se desenvolvem completamente após o desmame e o crescimento do bezerro. $\mathrm{O}$ desenvolvimento papilar e a especialização do epitélio ruminal durante o crescimento fetal e ao nascimento são dois processos independentes, que irão preparar o rúmen para sua adaptação à alimentação ruminante adulta. Assim, o estudo microscópico do epitélio ruminal nessas fases iniciais da vida é importante para a compreensão de como essa estrutura prepara o rúmen para lidar com o processo de desmame e a ativação funcional do rúmen. Vários estudos na área de nutrição de ruminantes buscam promover o máximo desenvolvimento das papilas ruminais e de seu epitélio o mais rápido possível com diferentes estratégias de desmame, contudo, para melhor controlar processos e prever resultados é preciso entender melhor como eles ocorrem, o que esperamos contribuir com este estudo. Do mesmo modo afirmam Steele et al. (2016), uma vez que o desenvolvimento estrutural do rúmen é promovido pelo consumo de alimentos sólidos durante o desmame dos bezerros. Quanto ao epitélio ruminal pavimentoso estratificado queratinizado do bovino adulto e suas papilas, os achados deste estudo corroboram com os achados de outros autores, como Graham e Simmons (2005), Scala et al. (2011) e Steele et al. (2015, 2016), onde é possível identificar diferentes camadas celulares no epitélio, o estrato córneo, o estrato granuloso, estrato espinhoso e a camada basal. Assim, as descrições do presente estudo estão de acordo com as encontradas na literatura, em relação à anatomia do órgão e sua histologia (DELLMANN; BROWN, 1982; BANKS, 1992; DELLMANN; CARITHERS, 1996; JUNQUEIRA; CARNEIRO, 2008; BACHA JR.; BACHA, 2012; KIERSZENBAUM; TRES, 2012).

O presente estudo realizou MET das porções dorsal e ventral do rúmen de fetos de 110 e 150 dias de desenvolvimento e bezerros recém-nascidos, onde foi possível observar algumas diferenças celulares entre as idades estudadas. Assim como demonstraram Groenewald (1993) e Steele et al. (2015), que trabalharam com cordeiros e bovinos (fetos e bezerros), respectivamente, as células da camada basal apresentaram núcleos grandes, às vezes arredondados; e nas células epiteliais foi possível observar grande quantidade de desmossomos nas membranas celulares. Dessa maneira, essa grande quantidade de desmossomos observada pode ser um indício da alta adesão celular no epitélio ruminal, impedindo que essas células se soltem facilmente e exponham a camada basal ruminal, proporcionando, então, uma rede celular estável que assegura o desenvolvimento da camada basal e das papilas ruminais, ainda em crescimento nos fetos de 150 dias e já em desenvolvimento nos bezerros recém-nascidos. Assim, seria necessária uma ação física, como a ingestão de alimentos sólidos, para que essas células se desprendam (sejam removidas por abrasão) do epitélio e deixem por completo as papilas expostas ao novo ambiente ruminal.

As diferentes conexinas, em resposta aos processos de adaptação e especialização funcional do epitélio ruminal, mudam sua dinâmica de expressão quanto ao seu tipo e sua localização, com repercussões na morfologia epitelial. 
Em relação à imunomarcação da Conexina 26, o presente estudo demonstrou sua presença no citoplasma de células da camada basal e do epitélio, além da sua presença na membrana plasmática das células epiteliais (principalmente em região mais apical), de ambas as idades de feto estudadas e dos bezerros recém-nascidos, sendo que no tecido adulto a marcação foi muito fraca. Nos bezerros a marcação foi mais intensa quando comparada às outras idades, sendo ela tanto citoplasmática quanto de membrana celular. No entanto, na porção dorsal do rúmen do feto de 150 dias foram encontradas possíveis marcações nucleares, que poderão ser confirmadas através de imunofluorescência de dupla marcação. Dessa maneira, por ser mais expressada nos animais mais jovens (fetos e bezerros), pode-se inferir que essa conexina seja necessária no desenvolvimento e na formação da arquitetura tecidual ruminal, não sendo mais tão importante no tecido adulto, o qual já possui sua arquitetura definida e não sofrerá mais desenvolvimento, sendo somente necessária a manutenção celular desse tecido. Esses dados podem ser corroborados por Silva et al. (2013) que, ao realizarem estudos com fibropapilomas cutâneos de bovinos, demonstraram a presença da Cx26 tanto em citoplasma das células da camada basal e do epitélio quanto em membrana citoplasmática dessas mesmas células. Além disso, também descreveram uma marcação para a Cx26 justanuclerar em algumas dessas células. Pfarrer et al. (2006), em seus estudos utilizando placentomas bovinos, demonstraram a localização da Cx26 na porção feto-maternal dos placentomas durante toda a prenhez, tanto em membrana plasmática quanto em citoplasma das células trofoblásticas gigantes. Essa desigualdade de marcação para a Cx26 entre as idades aqui estudadas pode ser considerada um indício de diferentes necessidades da presença dessa Cx durante o desenvolvimento e a manutenção do tecido ruminal.

Referente à imunomarcação para a Cx32 ocorreu marcação citoplasmática das células da camada basal e do citoplasma e de membrana celular no epitélio nos fetos e nos bezerros. No entanto, nos adultos, ocorreu somente marcação citoplasmática. Assim como correu com a Cx26, a marcação mais intensa nos animais mais jovens indica uma maior necessidade dessa proteína de junção gap para o desenvolvimento e formação tecidual do rúmen, sendo necessária para a conservação tecidual no tecido adulto, uma vez que ela se encontra no citoplasma celular, podendo se dirigir à membrana celular sempre que necessário. Esses dados corroboram com Pfarrer et al. (2006), que demonstraram a presença da Cx32 no citoplasma do epitélio caruncular durante todo o período gestacional. Assim como Johnson et al. (1999), que demonstraram a presença da Cx32 no citoplasma de oócitos, de folículos primários e secundários e de folículos atrésicos de vacas.

Na imunomarcação para a Cx40 ocorreu marcação citoplasmática na camada basal e tanto em citoplasma quanto em membrana celular do epitélio ruminal de todas as idades estudadas. Assim, pode-se inferir que essa seja uma proteína necessária na manutenção do tecido ruminal, sempre estando presente, seja na membrana (funcional) ou seja no citoplasma (para se dirigir à membrana quando houver maior necessidade), para que o tecido sempre mantenha sua ordem e para que as células estejam sempre em constante comunicação entre si, permitindo um melhor desenvolvimento tecidual e mantendo sua 
arquitetura diante de eventuais abrasões físicas proporcionadas por alimentos fibrosos. De acordo com Wang e Daniel (2001), ao estudarem conexinas na musculatura gastrointestinal de cães, a marcação da Cx40 foi observada na musculatura circular do esfíncter esofágico, do antro gástrico e do íleo, sendo ela de característica citoplasmática. Em seus estudos, Van Kempen e Jongsma (1999) demonstraram a presença da Cx40 em musculatura lisa e tecido endotelial da aorta e da artéria coronária de bovinos, com marcação citoplasmática e de membrana celular.

Em relação à marcação da $\mathrm{Cx} 43$, apesar dela ter sido menos intensa nos fetos quando comparada aos bezerros e adultos, ela também ocorreu em citoplasma de células da camada basal e em citoplasma e membrana plasmática das células epiteliais. Dessa maneira, sua expressão maior em tecidos mais desenvolvidos (bezerros e adultos) demonstra que essa conexina é mais importante durante uma fase mais tardia de desenvolvimento tecidual ruminal (bezerros) e na preservação do epitélio já desenvolvido (adultos), sendo somente necessária nos tecidos mais jovens (fetos) para manter a estrutura tecidual do rúmen. Segundo Johnson et al. (1999), independentemente da sua condição, os folículos bovinos apresentaram marcação para a Cx43 tanto nas células da granulosa quanto da teca. Pfarrer et al. (2006), ao estudar a expressão da Cx43 em placentomas bovinos durante a prenhez, demonstraram a marcação da Cx43 no estroma das criptas maternas e no mesênquima fetal durante todo o período gestacional. Além disso, Van Kempen e Jongsma (1999), mostraram em seu estudo a presença da Cx43 em tecido muscular liso da aorta e em tecido muscular liso e endotelial da artéria coronária de corações bovinos.

As junções de comunicação fornecem uma rota intercelular direta permitindo que células adjacentes em tecidos e órgãos se comuniquem através de moléculas reguladoras e de sinalização (GEORGE; KENDALL; EVANS, 1999).

Até o presente momento, poucos estudos foram realizados referentes à localização das Cx26, Cx32, Cx40 e Cx43 em bovinos, sendo que nenhum foi ainda realizado referente à essas conexinas e ao rúmen de fetos bovinos, bezerros recém-nascidos e bovinos adultos, dificultando possíveis comparações de resultados. Porém, este fato torna o presente estudo inédito na pesquisa de conexinas relacionadas ao desenvolvimento ruminal de bovinos.

Em relação à imunomarcação da E-caderina, o presente estudo demonstrou sua presença no citoplasma e na membrana de células da camada basal, além da sua presença na membrana plasmática das células epiteliais (de modo homogêneo), em ambas as idades de fetos estudadas, nos bezerros recém-nascidos e nos bovinos adultos. Nos fetos a marcação foi mais intensa quando comparada às outras idades, sendo ela tanto citoplasmática quanto de membrana celular. No entanto, essa marcação é mais intensa na porção ventral do rúmen, indicando uma maior adesão entre as células do seu epitélio. Nos bezerros, a marcação mostrou-se mais intensa em região de camada basal, principalmente no citoplasma celular, porém, nos adultos, a marcação foi mais evidente na membrana plasmática das células do epitélio estratificado. Dessa maneira, por ser mais 
expressada na camada basal dos animais mais jovens (fetos) e no epitélio dos animais mais desenvolvidos (bezerros e adultos) pode-se inferir que essa proteína de junção e adesão celular é necessária para desenvolvimento e formação da arquitetura tecidual ruminal dos fetos, sendo mais necessária para manutenção celular desse tecido nos bezerros e adultos. Esses achados estão de acordo com Kim et al., (2005), que relatam que a força de adesão célula-célula mediada pelas caderinas é regulada de modo dinâmico para adaptar processos como a migração celular durante a embriogênese, a renovação celular epitelial, a cura de feridas, a manutenção da integridade e da função tecidual em organismos adultos. De acordo com Maître e Heisenberg (2013), uma função da caderina na adesão célula-célula é promover a formação de contato, reduzindo diretamente a tensão superficial na interface célula-célula por meio da tensão de adesão. A tensão de aderência surge da ligação da caderina sobre o contato entre as células, gerando assim uma tensão negativa que expande a área de contato célula-célula. Além da tensão de aderência, as células também podem usar diferentes estratégias para reduzir a tensão interfacial no contato célula-célula e, assim, aumentar a área do contato. A contratilidade da actomiosina é um fator decisivo que influencia a tensão superficial das células em uma ampla variedade de organismos. Uma vez que as células entram em contato umas com as outras, elas frequentemente reorganizam o citoesqueleto de actomiosina na interface célula-célula, resultando em uma redução da tensão interfacial no contato, expandindo, assim, a área do contato. A reorganização mediada por contato do citoesqueleto de actomiosina é comumente atribuída à sinalização do complexo de adesão da caderina, embora outros processos independentes da caderina também possam controlar a organização do citoesqueleto de actomiosina no contato (MAÎTRE; HEISENBERG, 2013).

Além da verificação da presença das conexinas e da E-caderina nas células do tecido ruminal dos fetos bovinos, bezerros recém-nascidos e bovinos adultos, o presente estudo também avaliou geneticamente a expressão dessas proteínas através de análises biomoleculares.

As junções de comunicação fornecem uma rota intercelular direta permitindo que células adjacentes em tecidos e órgãos se comuniquem através de moléculas reguladoras e de sinalização (GEORGE; KENDALL; EVANS, 1999).

Quando feita a comparação de expressão gênica da Conexina 26 (Cx26) entre as idades estudadas, pode-se observar que nos fetos de 110 e 150 dias de desenvolvimento sua expressão é semelhante. Esse fato pode, também, ser observado nos resultados da imunofluorescência, onde a marcação para a Cx26 se mostrou semelhante nessas idades fetais, ocorrendo uma aparente marcação nuclear no s fetos de 150 dias. Apesar de semelhantes, os fetos de 150 dias apresentaram expressão da Cx26 ligeiramente superior aos fetos de 110 dias, o que pode explicar a presença dessa possível marcação nuclear nos fetos de 150 dias, uma vez que as conexinas são produzidas no retículo endoplasmático rugoso das células, passam pelo complexo de Golgi (onde são armazenadas temporariamente) e são encaminhadas para a membrana plasmática em momentos nos quais deverão atuar nos canais de comunicação intercelular (HERNANDEZ- 
BLAZQUEZ et al., 2001). Em relação à expressão nos bezerros recém-nascidos, ela mostrou-se superior à expressão encontrada nos fetos, também corroborando com os achados na imunofluorescência, onde os bezerros apresentaram marcação para a Cx26 mais intensa que nas outras idades. No entanto, nos adultos, apesar de apresentarem expressão semelhante e ligeiramente superior à dos bezerros, sua marcação na imunofluorescência foi menos intensa que dos bezerros. Isso pode ocorrer devido seu armazenamento no citoplasma, como observado nas marcações, sem que haja a necessidade da sua presença na membrana plasmática celular, nas junções de comunicação. De acordo com Evans (2015), as proteínas das junções comunicantes possuem uma entrega rápida de algumas horas e ocorrem cerca de dez vezes mais rápida que proteínas de membrana em geral. Após a transcrição, as conexinas são inseridas de maneira co-transducional no retículo endoplasmático, embora a Cx26 possa ser inserida pós-transducional diretamente na membrana plasmática. Além disso, Batissoco (2011) mostrou que mutações genéticas em locus DFNB1, onde está o gene GJB2, codificante da Cx26, são as causas mais frequentes de surdez de herança autossômica recessiva em humanos, demonstrando a grande importância dessa conexina também em outras espécies.

Em relação à Cx32, apesar de não ter ocorrido sua expressão gênica nas idades estudadas, ela pôde ser observada na imunofluorescência. Esse fato pode ter ocorrido devido à sua síntese e armazenamento nas células, em alguns sítios específicos, como no próprio núcleo ou no complexo de Golgi (citoplasma), ou até mesmo atuando na membrana citoplasmática, possibilitando sua visualização tanto em região citoplasmática quanto em região de membrana celular e, em alguns casos, também sendo visualizada no núcleo das células. George, Kendall e Evans (1999) demonstraram que as conexinas se acumulam em compartimentos intracelulares que correspondem ao retículo endoplasmático e ao complexo de Golgi em células em cultura e em tecidos. Desse modo, podemos inferir que a $\mathrm{Cx} 32$ ficou armazenada nos compartimentos intracelulares e foram enviadas para a membrana citoplasmática das células do epitélio ruminal quando da necessidade da formação das junções de comunicação, resultando nos nossos achados na imunofluorescência. Além da importância em tecidos epiteliais, estudam mostram que mutações no cDNA codificante da Cx32 pode implicar em neuropatia periférica CharcotMarie-Tooth ligada ao X (GEORGE; KENDALL; EVANS, 1999; KIM; HAN; KIM, 2017; KYRIAKOUDI et al., 2017; OKAMOTO et al., 2017; AGRAHARI et al., 2018).

Em relação à $\mathrm{Cx} 40$, sua expressão gênica foi semelhante entre os fetos, sendo maior que nos bezerros e nos adultos, que também apresentaram semelhança na sua expressão. Esse resultado corroborou com os resultados de imunofluorescência, onde as marcações apresentaram-se mais intensas nos fetos quando comparados com as demais idades estudadas. Além disso, os fetos também apresentaram marcação nuclear para a Cx40, indicando sua presença no núcleo celular, demonstrando sua síntese e armazenamento nas células da camada basal e do epitélio ruminal. No caso dos bezerros e adultos, ocorreu a presença da $\mathrm{Cx} 40$ principalmente em região citoplasmática, indicando, também, que essa proteína foi sintetizada e está armazenada em 
compartimentos específicos (retículo endoplasmático e complexo de Golgi), prontas para serem translocadas para a membrana plasmática quando da sua necessidade. Esses dados corroboram com os achados de Ahmad et al. (1999) e George, Kendall e Evans (1999). Em contrapartida, a Cx40 também está relacionada a outros órgãos, como por exemplo, nos olhos, participando da transferência do humor aquoso pelas células ciliadas pigmentadas e não pigmentadas do globo ocular (WANG et al., 2010) e sendo expressa na camada neural da retina de mamíferos (MATESIC; TILLEN; SITARAMAYYA, 2003).

Na comparação entre a expressão gênica da Cx43 nas diferentes idades estudadas, observou-se que os adultos apresentaram maior expressão, seguidos pelos bezerros, e os fetos apresentaram expressões semelhantes e menores. As imunofluorescências acompanham esses resultados, uma vez que os adultos apresentaram marcações mais intensas para a Cx43, seguidos pela marcação menos intensa nos bezerros e uma marcação mais suave nos fetos. Essa marcação mais intensa nos bovinos adultos pode ter ocorrido devido ao fato de serem animais fêmeas, produtoras de estrógenos, que são responsáveis pelo aumento da transcrição e síntese de Cx43 através da via da proteína-1 ativadora (AP-1) e do fator de transcrição Sp1 (ZHANG; CUI, 2017). Durante o reconhecimento materno da prenhez, o concepto (embrião) produz e secreta a proteína interferon-tau (INF- $\tau$ ), responsável por impedir o retorno da ciclicidade, preservando o funcionamento do corpo lúteo durante a gestação e inibindo a expressão dos receptores de estrógeno no epitélio do endométrio (PEREIRA et al., 2015). No entanto, com a evolução da gestação, os níveis de estrogênios passam a aumentar até chegarem a seus níveis máximos no final da gestação. Dessa maneira, pode-se inferir que a expressão da Cx43 pelos fetos ocorre devido à presença dos estrogênios circulantes no organismo materno, pois nesse período começa a ocorrer o aumento da produção estrogênica pela vaca até que essa produção seja máxima no momento do parto, implicando também na presença de expressão gênica da $\mathrm{Cx} 43$ nos bezerros recém-nascidos, fatos esses corroborados por Henricks (1976) e Facury Filho et al. (2016).

Quando realizada a comparação da expressão gênica da E-caderina entre as idades estudadas pôde-se observar que sua expressão se apresentou semelhante entre todas as idades. Isso se deve ao fato da E-caderina ser uma proteína transmembrânica de junção e adesão celular, relacionada à regulação da organização, morfogênese e homeostase tissular (PETTITT, 2005). A E-caderina confere às células a habilidade de aderência a células adjacentes, sendo essa uma propriedade fundamental na evolução da multicelularidade. Durante a morfogênese, tecidos podem mudar de tamanho e formato e formar camadas celulares distintas. A função das caderinas na morfogênese tissular é controlar tanto a adesão célula-célula quanto a sinalização celular (MAÎTRE; HEISENBERG, 2013). Devido às suas funções tão importantes na manutenção do tecido, a E-caderina deve ser encontrada em todas as idades do organismo, seja durante seu desenvolvimento uterino, durante seu crescimento após seu nascimento e durante toda as fases da vida, corroborando com os achados do presente estudo. 
Além disso, Hernandez-Blazquez et al., (2001) demonstraram a interação entre a E-caderina e as conexinas. Em seus estudos, eles mostraram que a movimentação das conexinas para a membrana plasmática para a formação das junções de comunicação ocorre através do controle pela E-caderina, em condições onde a quantidade de cálcio presente no meio extracelular seja adequada para a atuação da E-caderina. As caderinas necessitam de quantidades ótimas de cálcio extracelular para poderem realizar sua aderência com as caderinas das células vizinhas, formando as junções de adesão, para a manutenção da estrutura e da homeostase do tecido. Sem a presença do cálcio extracelular, as E-caderinas não são capazes de formarem as junções de adesão, incapacitando-as, também, da regulação da movimentação das conexinas para as membranas celulares. Dessa maneira, Hernandez-Blazquez et al., (2001) demonstraram que os complexos de adesão célula-célula formados pelas E-caderinas devem ser formados antes do transporte das conexinas para as membranas celulares. Esses complexos formados necessitam da interação de várias moléculas que agirão em conjunto, conectando a membrana ao citoesqueleto e estabilizando as ligações das Ecaderinas. Eles também mostraram em seus estudos que a formação das junções de aderência pelas E-caderinas ativa a formação de fibras de actina e que essas fibras são responsáveis pelo transporte das conexinas do complexo de Golgi para as membranas celulares para a formação das junções de comunicação. 
8 Conclusões 


\section{CONCLUSÕES}

O epitélio ruminal dos fetos de 150 dias de desenvolvimento é mais espesso quando comparado aos dos fetos de 110 dias de desenvolvimento, aos dos bezerros recém-nascidos e aos dos bovinos adultos.

A camada basal nas porções dorsal e ventral dos bovinos adultos é mais espessa que a camada basal encontrada nas outras idades estudadas, sendo que nos bezerros recém-nascidos a camada basal é a mais delgada.

Já é possível observar o início do desenvolvimento das papilas ruminais nos fetos de 150 dias de desenvolvimento. As papilas dos bovinos adultos são as mais desenvolvidas e apresentam tamanho maior na porção ventral ruminal.

Existe uma grande quantidade de desmossomos nas células epiteliais do rúmen de fetos bovinos e bezerros recém-nascidos.

A expressão das conexinas foi observada em citoplasma celular na camada basal e em citoplasma e membrana celular no tecido epitelial de todas as idades estudadas.

A expressão das conexinas estudadas difere em relação à idade dos animais e à localização no tecido ruminal, tornando evidente a necessidade de cada uma das conexinas em relação à idade, desenvolvimento e manutenção do tecido ruminal.

A expressão da E-caderina difere pouco entre as idades estudadas, demonstrando sua importância na manutenção e preservação tissular em todas as fases da vida dos bovinos, desde seu desenvolvimento fetal até a idade adulta.

A expressão gênica das conexinas demonstrou-se semelhante à expressão proteica observada nos tecidos ruminais em todas as idades, com exceção da conexina 32, a qual não apresentou expressão gênica em nenhuma das idades estudadas, apesar de apresentar expressão proteica no rúmen dos bovinos, sendo um indicativo de armazenamento dessa proteína para futura utilização. 
9 Referências 


\section{REFERÊNCIAS}

ABBAS, A. M.; ENGELHARDT, W. V; LECHNER DOLL, M.; LUCIANO, L.; MOUSA, H. M.; REALE, E. Particularities in forestomach anatomy, physiology and biochemistry of camelids compared to ruminants. Tisserand J. -L (ed). Elevage et Alimentation du dromadaire., p. 19-32, 1995.

AGRAHARI, A. K.; KUMAR, A.; R, S.; ZAYED, H.; C, G. P. D. Substitution impact of highly conserved arginine residue at position 75 in GJB1 gene in association with Xlinked Charcot-Marie-tooth disease: A computational study. Journal of Theoretical Biology, v. 437, p. 305-317, 21 jan. 2018. Disponível em: <https://www.sciencedirect.com/science/article/pii/S0022519317304976?via\%3Dihub>. Acesso em: 20 abr. 2018.

AHMAD, S.; DIEZ, J. A.; GEORGE, C. H.; EVANS, W. H. Synthesis and assembly of connexins in vitro into homomeric and heteromeric functional gap junction hemichannels. The Biochemical journal, v. 339 ( Pt 2), n. Pt 2, p. 247-53, 15 abr. 1999. Disponível em: <http://www.ncbi.nlm.nih.gov/pubmed/10191254>. Acesso em: 20 abr. 2018.

AVANZO, J. L.; MESNIL, M.; HERNANDEZ-BLAZQUEZ, F. J.; DA SILVA, T. C.; FUKUMASU, H.; MORI, C. M.; YAMASAKI, H.; DAGLI, M. L. Altered Expression of Connexins in Urethane-Induced Mouse Lung Adenomas. Life Sci, v. 79, p. 22022208, 2006. Disponível em: <http://www.ncbi.nlm.nih.gov/pubmed/16926031>.

BACHA JR., W. J.; BACHA, L. M. Color Atlas of Veterinary Histology. 3. ed. [s.1.] Wiley-Blackwell, 2012.

BANKS, W. J. Histologia Veterinária Aplicada. 2. ed. São Paulo: Manole, 1992.

BATISSOCO, A. C. A conexina 26 e sua relação com outras proteínas no órgão de Corti. 2011. Biblioteca Digital de Teses e Dissertações da Universidade de São Paulo, São Paulo, 2011. Disponível em:

<http://www.teses.usp.br/teses/disponiveis/41/41131/tde-18042012-120229/>. Acesso em: 20 abr. 2018.

BENJAMINI, Y.; HOCHBERG, Y. Controlling the False Discovery Rate: A Practical and Powerful Approach to Multiple Testing. Source Journal of the Royal Statistical Society. Series B (Methodological), v. 57, n. 1, p. 289-300, 1995. Disponível em: <http://www.jstor.org/stable/2346101>. Acesso em: 16 fev. 2018.

BEYER, E. C.; BERTHOUD, V. M. Gap junction gene and protein families: Connexins, innexins, and pannexins. Biochimica et Biophysica Acta (BBA) Biomembranes, v. 1860, n. 1, p. 5-8, 1 jan. 2018. Disponível em: <https://www.sciencedirect.com/science/article/pii/S0005273617301773?via\%3Dihub>. Acesso em: 16 abr. 2018.

BOURGON, R.; GENTLEMAN, R.; HUBER, W. Independent filtering increases detection power for high-throughput experiments. Proceedings of the National Academy of Sciences of the United States of America, v. 107, n. 21, p. 9546-51, 25 maio 2010. Disponível em: <http://www.ncbi.nlm.nih.gov/pubmed/20460310>. Acesso 
em: 15 fev. 2018.

BRUZZONE, R.; WHITE, T. W.; PAUL, D. L. Connections with Connexins: The Molecular Basis of Direct Intercellular Signaling. Eur J Biochem, v. 238, p. 1-27, 1996. Disponível em: 〈http://www.ncbi.nlm.nih.gov/pubmed/8665925>.

BUDRAS, K.-D.; HABEL, R. E. Bovine Anatomy: An Illustrated Text. 1. ed. Hannover, Germany: Schlütersche, 2003.

COGLIATI, B.; DA SILVA, T. C.; ALOIA, T. P.; CHAIBLE, L. M.; REAL-LIMA, M. A.; SANCHES, D. S.; MATSUZAKI, P.; HERNANDEZ-BLAZQUEZ, F. J.; DAGLI, M. L. Morphological and Molecular Pathology of CCL4-Induced Hepatic Fibrosis in connexin43-Deficient Mice. Microsc Res Tech, v. 74, p. 421-429, 2011. Disponível em: <http://www.ncbi.nlm.nih.gov/pubmed/20830702>.

CUNNINGHAM, J. G. Tratado de Fisiologia Veterinária. Terceira E ed. Rio de Janeiro, RJ: Guanabara-Koogan, 2004.

DAGLI, M. L.; HERNANDEZ-BLAZQUEZ, F. J. Roles of Gap Junctions and Connexins in Non-Neoplastic Pathological Processes in Which Cell Proliferation Is Involved. J Membr Biol, v. 218, p. 79-91, 2007. Disponível em:

<http://www.ncbi.nlm.nih.gov/pubmed/17653785>.

DELLMANN, H.-D.; BROWN, E. M. Histologia veterinária. [s.1.] Guanabara Koogan, 1982.

DELlmanN, H. D.; CARITHERS, J. R. Cytology and Microscopic Anatomy. USA: Williams and Wilkins, 1996.

DOBIN, A.; DAVIS, C. A.; SCHLESINGER, F.; DRENKOW, J.; ZALESKI, C.; JHA, S.; BATUT, P.; CHAISSON, M.; GINGERAS, T. R. STAR: ultrafast universal RNAseq aligner. Bioinformatics, v. 29, n. 1, p. 15, 2013. Disponível em:

<https://www.ncbi.nlm.nih.gov/pmc/articles/PMC3530905/>. Acesso em: 15 fev. 2018.

DUKES, H. H. Dukes' Physiology of Domestic Animals. 12th Editi ed. United States of America: Cornell University Press, 2004.

DYCE, K. M.; SACK, W. O.; WENSING, C. J. G. Textbook of Veterinary Anatomy. Fourth Edi ed. Saint Louis, Missouri, USA: Saunders Elsevier, 2010.

ENDO, K.; WATANABE, S.; NAGAHARA, A.; HIROSE, M.; SATO, N. Restoration of Gap Junctions in the Regenerative Process of Ethanol-Induced Gastric Mucosal Injury. J Gastroenterol Hepatol, v. 10, p. 589-594, 1995. Disponível em: <http://www.ncbi.nlm.nih.gov/pubmed/8963036>.

EVANS, W. H. Cell communication across gap junctions: a historical perspective and current developments. Biochemical Society transactions, v. 43, n. 3, p. 450-9, 1 jun. 2015. Disponível em: <http://www.ncbi.nlm.nih.gov/pubmed/26009190>. Acesso em: 16 abr. 2018.

EWING, B.; HILLIER, L.; WENDL, M. C.; GREEN, P. Base-calling of automated sequencer traces using phred. I. Accuracy assessment. Genome research, v. 8, n. 3, p. 175-85, 1 mar. 1998. Disponível em:

<http://www.ncbi.nlm.nih.gov/pubmed/9521921>. Acesso em: 15 fev. 2018. 
FACURY FILHO, E. J.; MOREIRA, T. F.; CARVALHO, A. U.; MENESES, R. M. Adaptações hormonais de vacas leiteiras no período de transição. Clínica, Reprodução \& Qualidade do Leite, 2016. Disponível em: <https://www.milkpoint.pt/seccaotecnica/qualidade-do-leite/adaptacoes-hormonais-de-vacas-leiteiras-no-periodo-detransicao-98685n.aspx>. Acesso em: 21 abr. 2018.

FRANDSON, R. D. Anatomia e Fisiologia dos Animais de Fazenda. Sétima Edi ed. Rio de Janeiro, RJ: Guanabara-Koogan, 2011.

GARCÍA, A.; MASOT, J.; FRANCO, A.; GÁZQUEZ, A.; REDONDO, E. Histomorphometric and Immunohistochemical Study of the Goat Rumen During Prenatal Development. The Anatomical Record: Advances in Integrative Anatomy and Evolutionary Biology, v. 295, n. 5, p. 776-785, maio 2012. Disponível em: <http://doi.wiley.com/10.1002/ar.22431>. Acesso em: 4 jul. 2016.

GENTLEMAN, R. C.; CAREY, V. J.; BATES, D. M.; BOLSTAD, B.; DETTLING, M.; DUDOIT, S.; ELLIS, B.; GAUTIER, L.; GE, Y.; GENTRY, J.; HORNIK, K.; HOTHORN, T.; HUBER, W.; IACUS, S.; IRIZARRY, R.; LEISCH, F.; LI, C.; MAECHLER, M.; ROSSINI, A. J.; SAWITZKI, G.; SMITH, C.; SMYTH, G.; TIERNEY, L.; YANG, J. Y. H.; ZHANG, J. Bioconductor: open software development for computational biology and bioinformatics. Genome biology, v. 5, n. 10, p. R80, 2004. Disponível em: <http://www.ncbi.nlm.nih.gov/pubmed/15461798>. Acesso em: 15 fev. 2018.

GEORGE, C. H.; KENDALL, J. M.; EVANS, W. H. Intracellular trafficking pathways in the assembly of connexins into gap junctions. The Journal of biological chemistry, v. 274, n. 13, p. 8678-85, 26 mar. 1999. Disponível em:

<http://www.ncbi.nlm.nih.gov/pubmed/10085106>. Acesso em: 20 abr. 2018.

GOMES, R. da C.; FEIJÓ, G. L. D.; CHIARI, L. Evolução e Qualidade da Pecuária Brasileira. EMBRAPA, 2017. Disponível em:

<https://www.embrapa.br/documents/10180/21470602/EvolucaoeQualidadePecuaria.pd f/64e8985a-5c7c-b83e-ba2d-168ffaa762ad>. Acesso em: 14 abr. 2018.

GRAHAM, C.; SIMMONS, N. L. Functional organization of the bovine rumen epithelium. American journal of physiology. Regulatory, integrative and comparative physiology, v. 288, n. 1, p. R173-81, jan. 2005. Disponível em: <http://www.ncbi.nlm.nih.gov/pubmed/15319221>. Acesso em: 4 jul. 2016.

GROENEWALD, H. B. Ultrastructure of the epithelium of the rumen, reticulum and omasum of grey, white and black Karakul lambs. The Onderstepoort journal of veterinary research, v. 60, n. 3, p. 197-204, set. 1993. Disponível em: <http://www.ncbi.nlm.nih.gov/pubmed/7970575>. Acesso em: 5 jul. 2016.

HENRICKS, D. M. Estrogen concentrations in bovine and porcine tissues. Journal of Toxicology and Environmental Health, v. 1, n. 4, p. 617-639, 19 mar. 1976.

Disponível em: <http://www.ncbi.nlm.nih.gov/pubmed/1263281〉. Acesso em: 21 abr. 2018.

HERNANDEZ-BLAZQUEZ, F. J.; JOAZEIRO, P. P.; OMORI, Y.; YAMASAKI, H. Control of Intracellular Movement of Connexins by E-Cadherin in Murine Skin Papilloma Cells. Experimental Cell Research, v. 270, p. 235-247, 2001. Disponível em: <https://ac.els-cdn.com/S001448270195342X/1-s2.0-S001448270195342X- 
main.pdf?_tid=4dee98be-a359-41df-b3ba-

5e724a5c3b59\&acdnat $=1525270643 \_6 e 09 b 7203 f 84997484 c a 891 b a 24 c 63 a c>$. Acesso em: 2 maio. 2018.

HIRABAYASHI, Y.; YOON, B. I.; TSUBOI, I.; HUO, Y.; KODAMA, Y.; KANNO, J.; OTT, T.; TROSKO, J. E.; INOUE, T. Protective Role of Connexin 32 in SteadyState Hematopoiesis, Regeneration State, and Leukemogenesis. Exp Biol Med (Maywood), v. 232, p. 700-712, 2007. Disponível em: <http://www.ncbi.nlm.nih.gov/pubmed/17463168>.

HYTTEL, P.; SINOWATZ, F.; VEJLSTED, M. Essentials of Domestic Animal Embryology. 1st Editio ed. [s.1.] Saunders Elsevier, 2010.

IGARASHI, I.; MAKINO, T.; KAI, K.; TERANISHI, M.; TAKASAKI, W.; SATOH, H.; FURUHAMA, K. Localization of connexin 32 in spontaneous liver lesions of mice. The Journal of veterinary medical science / the Japanese Society of Veterinary Science, v. 78, n. 1, p. 113-6, jan. 2016. Disponível em: <http://www.ncbi.nlm.nih.gov/pubmed/26268664>. Acesso em: 23 jun. 2016.

JOHNSON, M. L.; REDMER, D. A.; REYNOLDS, L. P.; GRAZUL-BILSKA, A. T. Expression of Gap Junctional Proteins Connexin 43, 32, and 26 Throughout Follicular Development and Atresia in Cows. Endocrine, v. 10, n. 1, p. 43-52, 1999. Disponível em: <http://link.springer.com/10.1385/ENDO:10:1:43>. Acesso em: 23 jun. 2016.

JUNQUEIRA, L. C. U.; CARNEIRO, J. Histologia Básica. 11. ed. Rio de Janeiro: Guanabar-Koogan, 2008.

KIERSZENBAUM, A. L.; TRES, L. L. Histologia e Biologia Celular: Uma Introdução à Patologia. 3. ed. Rio de Janeiro, RJ: Elsevier, 2012.

KIM, J. K.; HAN, S.-A.; KIM, S. J. X-linked Charcot-Marie-Tooth disease with GJB1 mutation presenting as acute disseminated encephalomyelitis-like illness: A case report. Medicine, v. 96, n. 49, p. e9176, dez. 2017. Disponível em: <http://www.ncbi.nlm.nih.gov/pubmed/29245364>. Acesso em: 20 abr. 2018.

KIM, Y. J.; SAUER, C.; TESTA, K.; WAHL, J. K.; SVOBODA, R. A.; JOHNSON, K. R.; WHEELOCK, M. J.; KNUDSEN, K. A. Modulating the strength of cadherin adhesion: evidence for a novel adhesion complex. Journal of cell science, v. 118, n. Pt 17, p. 3883-94, 1 set. 2005. Disponível em:

<http://www.ncbi.nlm.nih.gov/pubmed/9739078>. Acesso em: 2 maio. 2018.

KYRIAKOUDI, S.; SARGIANNIDOU, I.; KAGIAVA, A.; OLYMPIOU, M.; KLEOPA, K. A. Golgi-retained Cx32 mutants interfere with gene addition therapy for CMT1X. Human Molecular Genetics, v. 26, n. 9, p. 1622-1633, 1 maio 2017. Disponível em: <https://academic.oup.com/hmg/article/26/9/1622/3039198>. Acesso em: 20 abr. 2018.

LOEWENSTEIN, W. R. Junctional Intercellular Communication and the Control of Growth. Biochim Biophys Acta, v. 560, p. 1-65, 1979. Disponível em: <http://www.ncbi.nlm.nih.gov/pubmed/216404>.

LORDÃO, A. da C.; VISCARDI, B. S. M.; OLIVEIRA, M. dos S. S.; PERES, M. P. Indicadores IBGE. 2017. Disponível em: 
<https://biblioteca.ibge.gov.br/visualizacao/periodicos/2380/epp_2017_dez.pdf>. Acesso em: 14 abr. 2018.

LOVE, M. I.; HUBER, W.; ANDERS, S. Moderated estimation of fold change and dispersion for RNA-seq data with DESeq2. Genome biology, v. 15, n. 12, p. 550, 2014. Disponível em: <http://www.ncbi.nlm.nih.gov/pubmed/25516281>. Acesso em: 15 fev. 2018.

MAÎTRE, J.-L.; HEISENBERG, C.-P. Three functions of cadherins in cell adhesion. Current biology : CB, v. 23, n. 14, p. R626-33, 22 jul. 2013. Disponível em: <http://www.ncbi.nlm.nih.gov/pubmed/23885883>. Acesso em: 13 abr. 2018.

MATESIC, D.; TILLEN, T.; SITARAMAYYA, A. Connexin 40 expression in bovine and rat retinas. Cell Biology International, v. 27, n. 2, p. 89-99, 2003.

NODEN, D. M.; LAHUNTA, A. de. The embryology of domestic animals. Developmental mechanisms and malformations. 1st Editio ed. Zaragoza, Spain: Acribia, S. A., 1990.

OKAMOTO, T.; KAWAMOTO, E.; TAKAGI, Y.; AKITA, N.; HAYASHI, T.; PARK, E. J.; SUZUKI, K.; SHIMAOKA, M. Gap junction-mediated regulation of endothelial cellular stiffness. Scientific reports, v. 7, n. 1, p. 6134, 21 jul. 2017. Disponível em: <http://www.ncbi.nlm.nih.gov/pubmed/28733642>. Acesso em: 20 abr. 2018.

PEREIRA, M. A.; OLIO, R. L.; SANTOS, A. C.; VIANA, D. C.; FAVARON, P. O.; MIGLINO, M. A. Reconhecimento materno da gestação em animais de produção.

Journal of Continuing Education in Animal Science of CRMV-SP, v. 13, n. 1, p. 30-35, 2015. Disponível em:

<https://www.researchgate.net/profile/Diego_Viana/publication/275771175_Reconheci mento_materno_da_gestacao_em_animais_de_producao_Maternal_recognition_of_preg nancy_in_livestock_animals/links/55468a280cf23ff71686d79f/Reconhecimentomaterno-da-gestacao-em-an>. Acesso em: 21 abr. 2018.

PETTITT, J. The Cadherin Superfamily. WormBook, p. 1-9, 2005. Disponível em: <http://www.ncbi.nlm.nih.gov/pubmed/18050421>.

PFARRER, C. D.; HEEB, C.; LEISER, R. Expression of gap junctional connexins 26, 32 and 43 in bovine placentomes during pregnancy. Placenta, v. 27, n. 1, p. 79-86, 2006.

SANECKA, A.; BIERNACKA, E. K.; SOSNA, M.; MUELLER-MALESINSKA, M.; PLOSKI, R.; SKARZYNSKI, H.; PIOTROWICZ, R. Evaluation of electrocardiographic parameters in patients with hearing loss genotyped for the connexin 26 gene (GJB2) mutations. Brazilian Journal of Otorhinolaryngology, 2016.

SCALA, G.; CORONA, M.; MARUCCIO, L. Structural, Histochemical and Immunocytochemical Study of the Forestomach Mucosa in Domestic Ruminants. Anatomia, Histologia, Embryologia, v. 40, n. 1, p. 47-54, fev. 2011. Disponível em: <http://doi.wiley.com/10.1111/j.1439-0264.2010.01037.x>. Acesso em: 18 jan. 2017.

SILVA, M. A.; ALTAMURA, G.; CORTEGGIO, A.; ROPERTO, F.; BOCANETI, F.; VELESCU, E.; FREITAS, A. C.; CARVALHO, C. C. R.; CAVALCANTI, K. P. S.; 
BORZACCHIELLO, G. Expression of connexin 26 and bovine papillomavirus E5 in cutaneous fibropapillomas of cattle. The Veterinary Journal, v. 195, n. 3, p. 337-343, 2013.

STEELE, M. A.; PENNER, G. B.; CHAUCHEYRAS-DURAND, F.; GUAN, L. L. Development and physiology of the rumen and the lower gut: Targets for improving gut health. Journal of Dairy Science, v. 99, n. 6, p. 4955-4966, 2016.

STEELE, M. A.; SCHIESTEL, C.; ALZAHAL, O.; DIONISSOPOULOS, L.; LAARMAN, A. H.; MATTHEWS, J. C.; MCBRIDE, B. W. The periparturient period is associated with structural and transcriptomic adaptations of rumen papillae in dairy cattle. Journal of Dairy Science, v. 98, n. 4, p. 2583-2595, 2015.

TAVORA, F.; ZHANG, M.; CRESSWELL, N.; LI, L.; FOWLER, D.; FRANCO, M.; BURKE, A. Quantitative Immunohistochemistry of Desmosomal Proteins (Plakoglobin, Desmoplakin and Plakophilin), Connexin-43, and N-cadherin in Arrhythmogenic Cardiomyopathy: An Autopsy Study. The open cardiovascular medicine journal, v. 7, p. 28-35, 2013. Disponível em: 〈http://www.ncbi.nlm.nih.gov/pubmed/23802019>. Acesso em: 16 abr. 2018.

TROSKO, J. E.; CHANG, C. C.; MADHUKAR, B. V. Modulation of Intercellular Communication during Radiation and Chemical Carcinogenesis. Radiat Res, v. 123, p. 241-251, 1990. Disponível em: <http://www.ncbi.nlm.nih.gov/pubmed/2217720>.

VAN KEMPEN, M. J. A.; JONGSMA, H. J. Distribution of connexin37, connexin40 and connexin 43 in the aorta and coronary artery of several mammals. Histochem Cell Biol, n. 112, p. 479-486, 1999.

VAN SOEST, P. J. Nutritional ecology of the ruminants. Cornell University Press, v. 2, p. 11-45, 1982.

WANG, C. M.; LINCOLN, J.; COOK, J. E.; BECKER, D. L. Abnormal Connexin Expression Underlies Delayed Wound Healing in Diabetic Skin. Diabetes, v. 56, p. 2809-2817, 2007. Disponível em: <http://dx.doi.org/10.2337/db07-0613>.

WANG, Y. F.; DANIEL, E. E. Gap Junctions in Gastrointestinal Muscle Contain Multiple Connexins. Am J Physiol Gastrointest Liver Physiol, v. 281, p. G533-43, 2001. Disponível em: <http://www.ncbi.nlm.nih.gov/pubmed/11447034>.

WANG, Z.; DO, C. W.; VALIUNAS, V.; LEUNG, C. T.; CHENG, A. K. W.; CLARK, A. F.; WAX, M. B.; CHATTERTON, J. E.; CIVAN, M. M. Regulation of gap junction coupling in bovine ciliary epithelium. American journal of physiology. Cell physiology, v. 298, n. 4, p. C798-806, abr. 2010. Disponível em: <http://www.ncbi.nlm.nih.gov/pubmed/20089928>. Acesso em: 23 jun. 2016.

WILSON, M. R.; CLOSE, T. W.; TROSKO, J. E. Cell Population Dynamics (Apoptosis, Mitosis, and Cell-Cell Communication) during Disruption of Homeostasis. Exp Cell Res, v. 254, p. 257-268, 2000. Disponível em: <http://www.ncbi.nlm.nih.gov/pubmed/10640424>.

ZHANG, X.-F.; CUI, X. Connexin 43: Key roles in the skin. Biomedical reports, v. 6, n. 6, p. 605-611, jun. 2017. Disponível em: <http://www.ncbi.nlm.nih.gov/pubmed/28584630>. Acesso em: 16 abr. 2018. 


\begin{abstract}
APÊNDICE
Figura 1: Gráfico da diferença de expressão entre Fetos de 110 dias e Fetos de 150 dias de desenvolvimento, em $\log 2$ (fold-change), versus significância do teste de expressão diferencial, em $\log 10$ (fdr). Pontos em vermelho indicam genes significativamente mais expressos em Fetos de 110 dias, pontos em verde indicam genes significativamente mais expressos em Fetos de 150 dias.
\end{abstract}

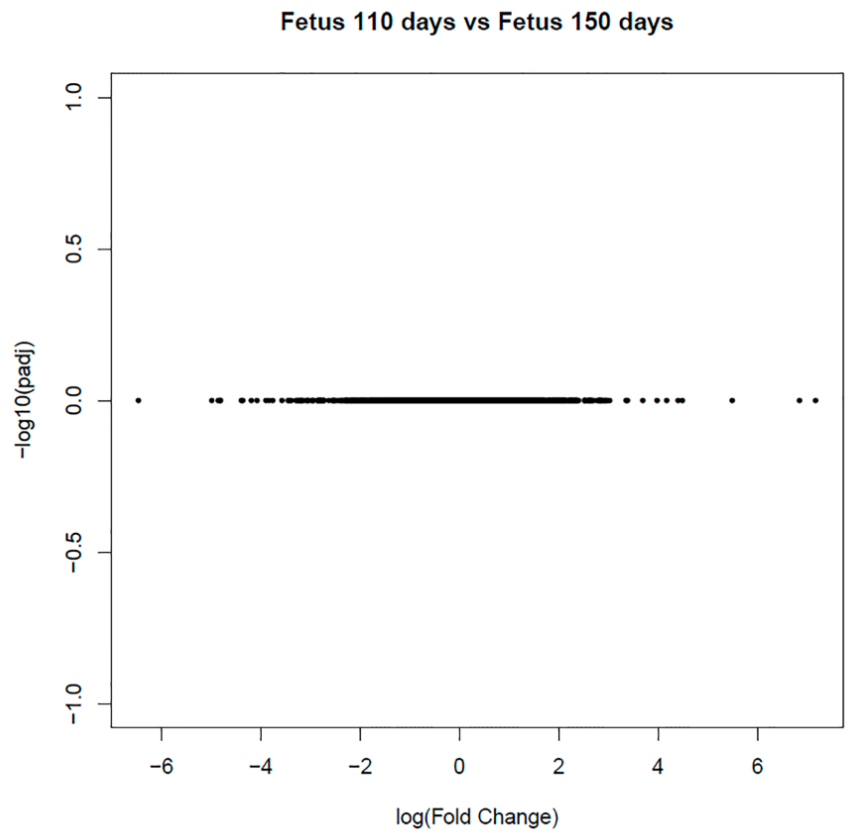

Figura 2: Gráfico da diferença de expressão entre Fetos de 110 dias e Bezerros recém-nascidos, em $\log 2$ (fold-change), versus significância do teste de expressão diferencial, em log10(fdr). Pontos em vermelho indicam genes significativamente mais expressos em Fetos de 110 dias, pontos em verde indicam genes significativamente mais expressos em Bezerros.

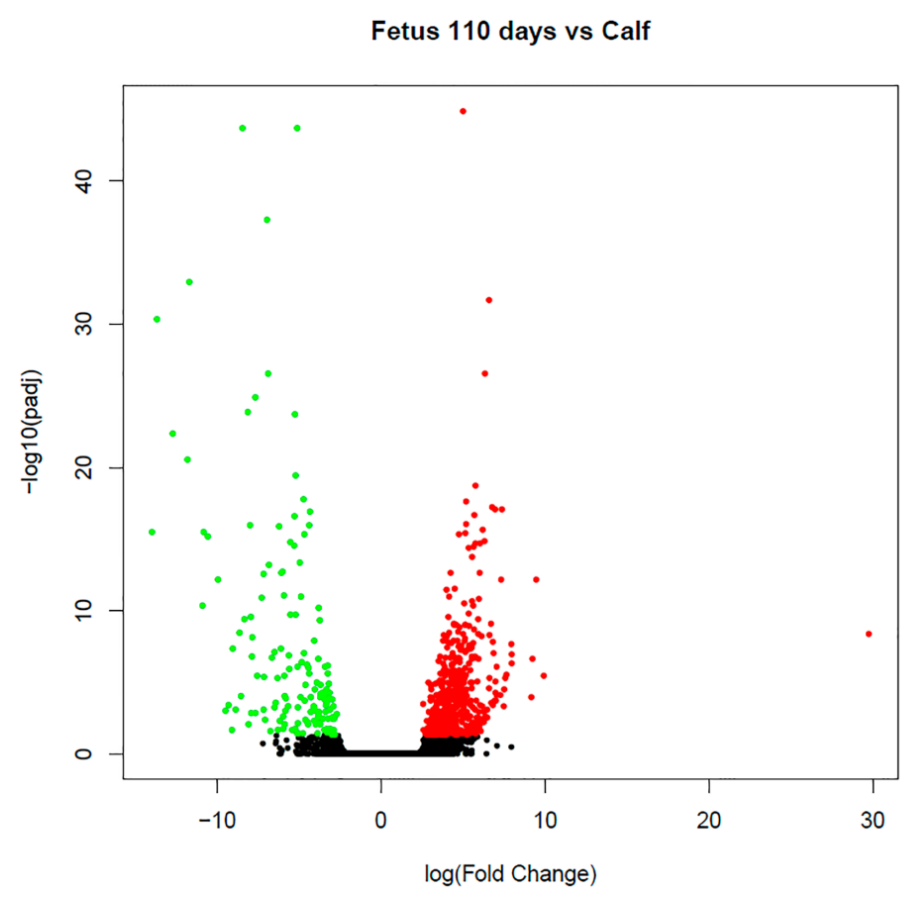


Figura 3: Gráfico da diferença de expressão entre Fetos de 110 dias e Bovinos Adultos, em log2(foldchange), versus significância do teste de expressão diferencial, em log10(fdr). Pontos em vermelho indicam genes significativamente mais expressos em Fetos de 110 dias, pontos em verde indicam genes significativamente mais expressos em Adultos.

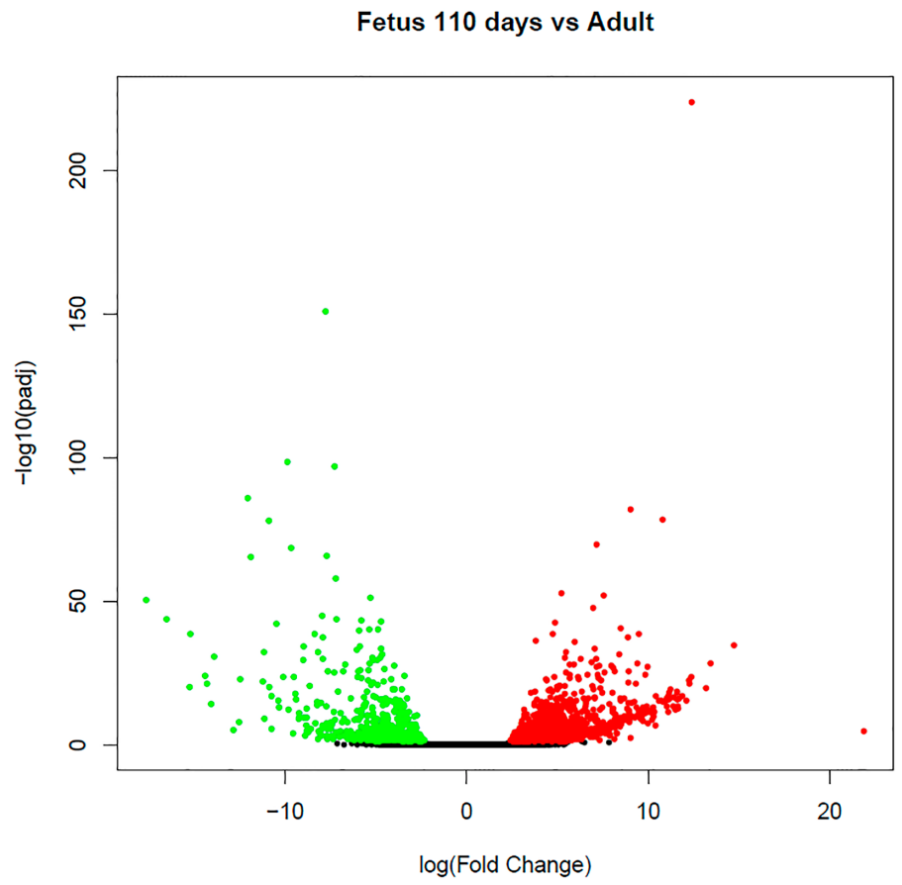

Figura 4: Gráfico da diferença de expressão entre Fetos de 150 dias e Bezerros, em log2(fold-change), versus significância do teste de expressão diferencial, em $\log 10(\mathrm{fdr})$. Pontos em vermelho indicam genes significativamente mais expressos em Fetos de 150 dias, pontos em verde indicam genes significativamente mais expressos em Bezerros.

Fetus 150 days vs Calf

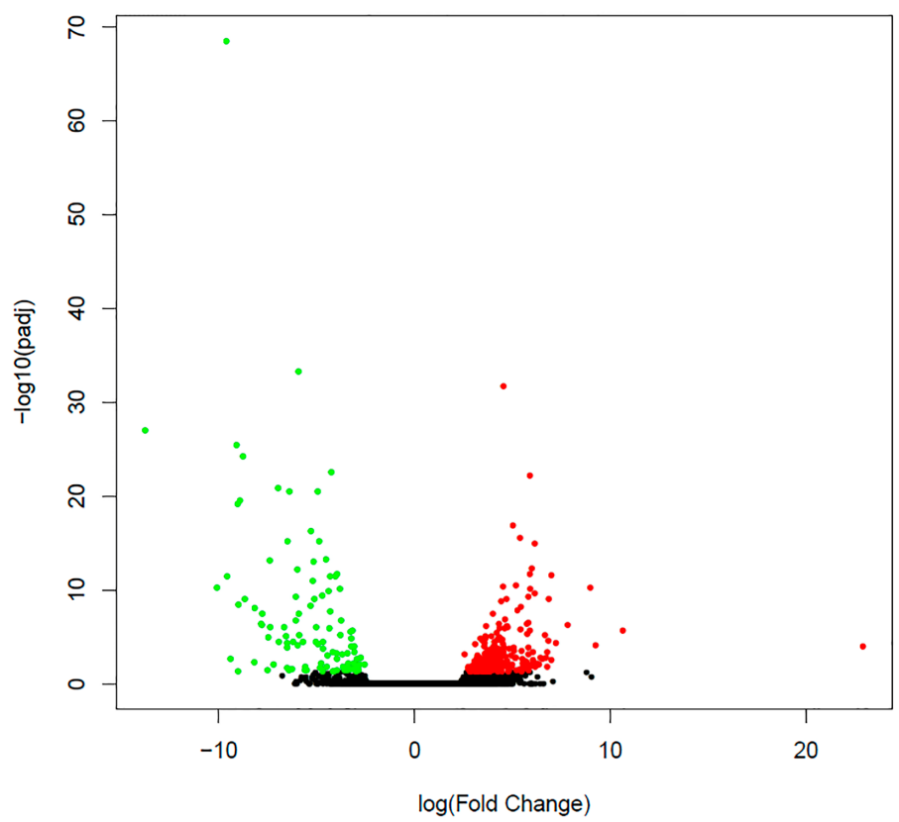


Figura 5: Gráfico da diferença de expressão Fetos de 150 dias e Bovinos Adultos, em log2(fold-change), versus significância do teste de expressão diferencial, em $\log 10(\mathrm{fdr})$. Pontos em vermelho indicam genes significativamente mais expressos em Fetos de 150 dias, pontos em verde indicam genes significativamente mais expressos em Adultos.

Fetus 150 days vs Adult

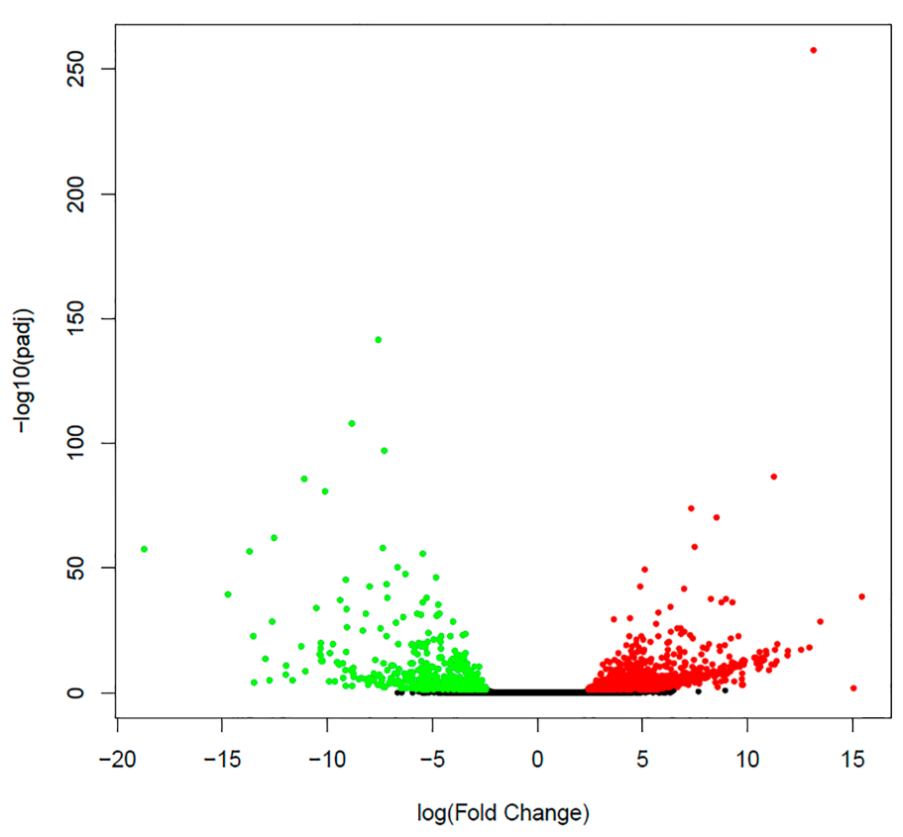

Figura 6: Gráfico da diferença de expressão Bezerros recém-nascidos e Bovinos Adultos, em log2(foldchange), versus significância do teste de expressão diferencial, em log10(fdr). Pontos em vermelho indicam genes significativamente mais expressos em Bezerros, pontos em verde indicam genes significativamente mais expressos em Adultos.

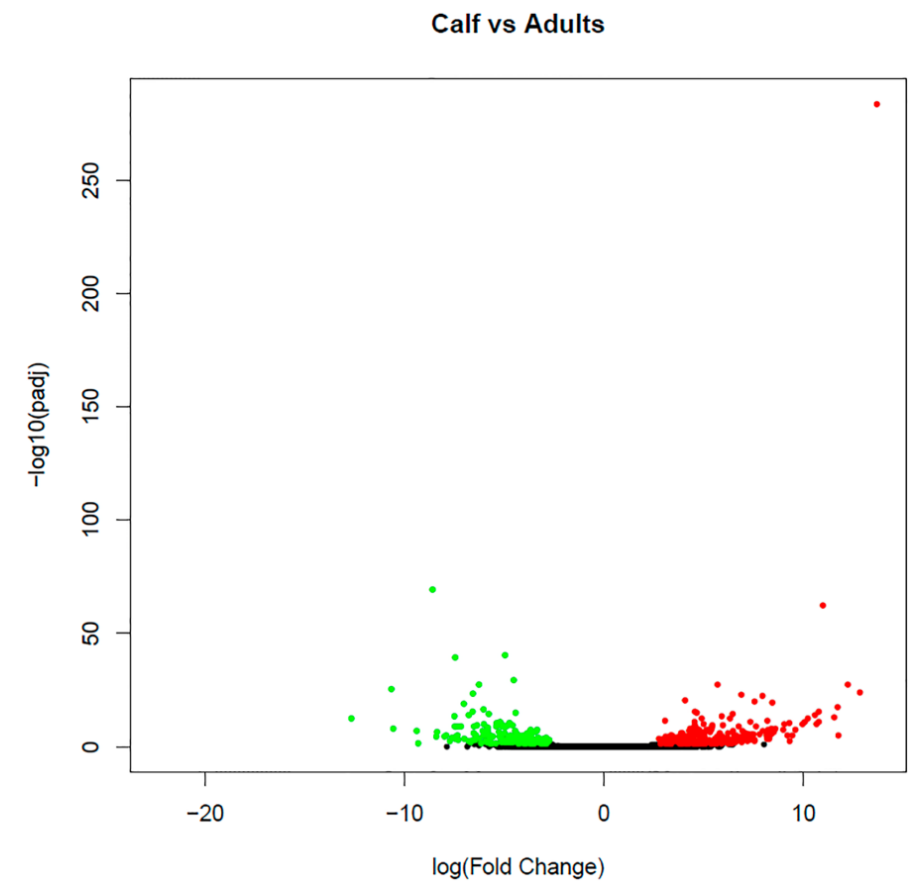

